\title{
When a mid-ocean ridge encroaches a continent: Seafloor- type hydrothermal activity in Lake Asal (Afar Rift)
}

\author{
Dekov V.M. ${ }^{1,}$, , Guéguen B. ${ }^{2,3}$, Yamanaka T. ${ }^{1}$, Moussa N. ${ }^{4}$, Okumura T. ${ }^{5}$, Bayon Germain ${ }^{6}$,
}

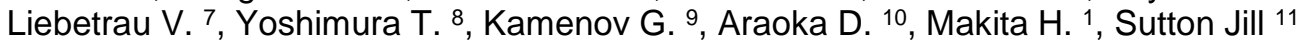

${ }^{1}$ Department of Ocean Sciences, Tokyo University of Marine Science and Technology, 4-5-7 Konan, Minato-ku, Tokyo 108-8477, Japan

${ }^{2}$ CNRS, Univ Brest, UMR 6538 Laboratoire Géosciences Océan, F-29280 Plouzané, France

${ }^{3}$ CNRS, Univ Brest, UMS 3113, F-29280 Plouzané, France

${ }^{4}$ IST, Centre d'Etude et de Recherche de Djibouti (CERD), BP 486, Route de l'Aéroport, Djibouti

5 Center for Advanced Marine Core Research, Kochi University, 200 Monobe-Otsu, Nankoku, Kochi

783-8502, Japan

6 IFREMER, Marine Geosciences Unit, 29280 Plouzané, France

${ }^{7}$ Helmholtz Centre for Ocean Research Kiel, GEOMAR, Wischhofstr. 1-3, D-24124 Kiel, Germany

8 Japan Agency for Marine-Earth Science and Technology (JAMSTEC), Research Institute for Marine

Resources Utilization, Biogeochemistry Program, 2-15 Natsushima-cho, Yokosuka-city, Kanagawa,

237-0061, Japan

${ }^{9}$ Department of Geological Sciences, University of Florida, 241 Williamson Hall, Gainesville, FL 32611, USA

${ }^{10}$ Geological Survey of Japan (GSJ), National Institute of Advanced Industrial Science and Technology (AIST), Central-7, 1-1-1 Higashi, Tsukuba, Ibaraki 305-8567, Japan

${ }_{11}$ Univ Brest, CNRS, IRD, Ifremer, Institut Universitaire Européen de la Mer, LEMAR, Rue Dumont d'Urville, 29280 Plouzané, France

*Corresponding author : V. M. Dekov, email address : vdekov0@kaiyodai.ac.jp

\begin{abstract}
:
At the place where the submarine Aden Ridge encroaches on the African continent and interacts with the East African Rift system, two small basins form: Ghoubbet-al-Kharab and Lake Asal. Whereas Ghoubbetal-Kharab is connected to the open ocean, Lake Asal is a typical example of oceanic "embryo", which is defined as a system that is detached from the ocean, but has features of a marine basin with an oceanic type crust and a seawater-based water body. In order to shed light on the source of water, type of hydrothermal activity and hydrothermal deposits, and controls on the water chemistry in an oceanic "embryo", we undertook a mineralogical-geochemical study of the lake water, hydrothermal fluids and hydrothermal carbonate deposits of Lake Asal. The geochemical analyses of lake water and hydrothermal fluids show that Lake Asal (located in an arid zone with strong evaporation and with no riverine input) is fed by seafloor-type hydrothermal fluids according to the following scenario: percolation of seawater along faults and cracks of extension in the rift, reaction of seawater with the hot basaltic rocks and hydrothermal fluid generation, discharge of the hydrothermal fluid in the Asal depression and accumulation of the Lake Asal water body. The fluid venting at the Lake Asal bottom is a mixture of $97 \%$ end-member hydrothermal fluid and 3\% lake water. The calculated end-member hydrothermal fluid of this oceanic "embryo" is poorer in metals than the seafloor hydrothermal fluids of an open and evolved ocean. In addition to the
\end{abstract}


seawater/rock interaction, the chemistry of Lake Asal is also controlled by evaporation leading to hyper salinity. In a hyper saline water body a number of hydrothermally supplied metals are stabilized as chloride complexes and accumulate. This results in a metal rich and mildly acidic "embryonic" ocean. Unlike an open and evolved modern ocean, the "embryonic" ocean located in an arid zone has heavy $\mathrm{C}$ and $\mathrm{O}$ isotope composition and light $\mathrm{Zn}$ and $\mathrm{Fe}$ isotope composition. Calcium isotope compositions of both types of ocean are similarly heavy. There are two genetically different sources of elements to the Lake Asal that are vertically separated: hydrothermal (lower, or bottom) and aeolian (upper, or surficial). Another important control on the lake water chemistry is the formation of carbonate spires at the lake bottom. Ca-carbonate precipitation immobilizes substantial amount of hydrothermally supplied $\mathrm{Ca}$ and drives up the $(\mathrm{Mg} / \mathrm{Ca}) \mathrm{mol}$ of the lake water. Increasing $(\mathrm{Mg} / \mathrm{Ca}) \mathrm{mol}$ of the evolving lake water leads to changes in the mineralogy of spires: from low-Mg calcite to aragonite. Thus, the spire formation exerts a self-control on its mineralogy. Carbonate spire deposition affects also the $\mathrm{Ca}, \mathrm{Zn}$ and $\mathrm{Fe}$ isotope composition of the lake water through adsorption or/and co-precipitation induced isotope fractionation.

\section{Highlights}

- Lake Asal (Afar Rift) is fed by seafloor-type hydrothermal fluids. An oceanic "embryo" in arid climate is mildly acidic and metal rich. It has heavy $\mathrm{C}, \mathrm{O}$ and $\mathrm{Ca}$, and light $\mathrm{Zn}$ isotope composition. Lake chemistry is controlled by hydrothermal discharge and aeolian input.

Keywords : Asal Rift, carbonate spires, C-O-Ca-Fe-Zn-Sr-U-Th isotopes, continental rift, "embryonic" ocean, seafloor hydrothermal activity 


\section{Introduction}

At present we have extensive understanding of the hydrothermal processes and related mineral deposits at all tectonic settings in the open ocean: mid-ocean ridges, volcanic arcs, back-arc spreading centers, and hot spots (German and Von Damm, 2004). Our knowledge of the same type of processes and deposits at continental rift setting is also substantial (Tiercelin et al., 1993; Benson, 1994; Pflumio et al., 1994; Barrat et al., 2000; Rosen et al., 2004; Branchu et al., 2005; Granina et al., 2007; Renaut et al., 2013; Dekov et al., 2014). However, the hydrothermal processes and deposits at the transition from continental rifting $u$ oceanic spreading in sensu stricto, at the point of mid-ocean ridge encroachment on a cor 'ine t where oceanic "embryos" form on land, are not well understood. In fact, there is c lly one place on Earth where this happens: the Asal Rift (East Africa) (Fig. 1 A). The Asn.1 kift, a part of the Asal-Ghoubbet Rift (Fig. 1 A), forms where the submarine Aden Ridge imn ${ }_{1}$ " $\mathrm{es}$ on the continent and interacts with the continental East African Rift system. Two sr a' ' basins form at the point of impingement: Ghoubbet-al-Kharab and Lake Asal (Fig. 1^). The Ghoubbet-al-Kharab is a semi-closed basin connected with the ocean (Bäcker et al., 1 $^{\text {Y }}$ ) whereas Lake Asal is a landlocked hypersaline $(\sim 300 \%$ ) basin with a dense network of hydrothermal manifestations around it (Gasse and Fontes, 1989).

The scarce knowledge on these processes and deposits motivated us to undertake mineralogical and geochemica. $1 \mathrm{~h} \cdot$ restigations at this oceanic "embryo" in order to answer three major questions: (1) What is i.e source of water in an oceanic "embryo" isolated from the ocean with no riverine supply $7 \mathrm{I}^{\mathrm{N}}$ " " nere evaporation is dominant over rainfall?, (2) What is the type of hydrothermal activity inr. deposits at the transitional setting of continental rifting - oceanic spreading?, and (3) What are the major controls on the chemistry of an ocean at the "embryonic" stage?

\section{Geological setting}

The Aden Ridge, a ridge system in the NW Indian Ocean that separates the Arabian and Somalian plates, is known to have propagated westward to the western tip of the Gulf of Tadjoura where it encroaches on the African continent (Courtillot et al., 1980, 1984; Manighetti et al., 
1998). Here, at the Afar region, the Red Sea spreading ridge has also jumped on land. Both spreading ridges meet the East African Rift and form a triple junction between the separating Arabian, Somalian and Nubian plates (Manighetti et al., 1998). Over the past 30 million years the rifting in the Afar region has evolved from continental extension to nascent seafloor spreading (Audin et al., 2004; Bastow and Keir, 2011; Wright et al., 2012).

Tadjoura Rift (Fig. 1 A) is the last submarine segment of the Aden Ridge. The first segment of the ridge that is exposed above sea level is the Asal-Ghoubbet Rift (Fig. 1 A). Morphologically, it is a NW-SE striking graben bounded by steep, inward dipping normal fault scarps (Stein et al., 1991) (Fig. 1 A,B). According to its crustal structure, magmatic rocesses, and tectonics, the Asal-Ghoubbet Rift is similar to slow-spreading ridges (Barbc -i e al., 1972; Needham et al., 1976; Manighetti et al., 1998). It is currently opening at $16 \pm 1 \mathrm{~nm} / \mathrm{yr}$ (Vigny et al., 2007) and propagates northwestward (Manighetti et al., 1998).

The crust of the Asal Rift is dominantly basaltic (Bartu ${ }^{*}+t$ al., 1993). Volcanism in and around the Asal Rift is a tectonically-controlled associati on $v^{f}$ typical oceanic basaltic volcanism (along the rift axis) and typical continental rift volc ${ }^{-i}$ s.. $^{-}$(on both sides of the rift axial zone) (Barberi et al., 1972). Early studies (Stieltjes, 1975) in? red that this volcanism is fed by a magma chamber still present below the central part of thu rift. Recent seismological investigations (Doubre et al., 2007) showed that the central Fieale-.st at * Bay volcanic complex is an important element of the rift plumbing system. The Fieale $:$ nd shark Bay calderas were inferred to overlay a $\sim 2$-km-wide pipe of hot rocks above a dec ne $>>5-6 \mathrm{~km}$ ) magma chamber. This conclusion is supported by endogenous heat studies in ginnermal wells in the Asal Rift revealing temperatures of up to $358^{\circ} \mathrm{C}$ at $\sim 2000 \mathrm{~m}$ dep. ${ }^{h}\left(7^{7} \cdot\right.$, et al., 1990). The dominantly basaltic crust of the rift between the Lake Asal and Ghoubbe - - 1 -Kharab is cut by clusters of open fissures (up to several meters wide) parallel to the normal faults (Vellutini, 1990; Manighetti et al., 1998) and therefore, the crust appears to be highly permeable.

\section{Samples}

During two sampling campaigns at the Afar Rift (Republic of Djibouti) in April and November 2017, we collected two major types of samples from the Lake Asal: fluids and carbonate spires (Fig. 1 A,B). For comparison, we collected the same types of samples from the 
Lake Abhé (Fig. 1 A,B): a lake located in a continental rift setting, in arid zone with dominance of evaporation over rainfall, but fed by river water (Awash River) (Dekov et al., 2014). In addition to these samples we also collected samples from the local basalts (Site 6, Lake Asal; Fig. 1 B) and salts precipitated at the Lake Asal bottom (Site 4; Fig. 1 B).

The fluid samples were of three sub-types: lake water, hot spring water (hydrothermal fluid) and seawater (Table 1). Seawater from Ghoubbet-al-Kharab (Fig. 1 B, Table 1) was sampled as a baseline for our fluid study. Lake water samples were collected at sites close to the lake shores and along two vertical profiles ( $\mathrm{C} 1$ and $\mathrm{C} 2$ ) across the Lake Asal water body (Table 1; Fig. 1 A,B). Hydrothermal fluids were collected from hot springs jetin a at the lake shores. After preliminary measurement of some basic physical-chemical paran ete $\mathrm{s}$ of the sampled fluids $(\mathrm{pH}$, $\mathrm{T}$, alkalinity, density, dissolved oxygen and dissolved inorga ic ( arbon; Table 1) we focused our further studies on a refined selection of samples: (1) spava ar; (2) Lake Asal (lake water from both vertical profiles across the lake, two hydrothermal "aids); (3) Lake Abhé (one lake water and two hydrothermal fluid samples).

The fluid samples were collected with hu, $50 \mathrm{~mL}$ syringes (TERUMO; cleaned with ultrapure $\mathrm{HNO}_{3}$ ) (seawater, hydrothermal "dids and nearshore lake water) and standard $5 \mathrm{~L}$ Niskin bottle (lake water vertical profiı ). Immediately after sample recovery $100 \mathrm{~mL}$ of each sample were filtered $(0.2 \mu \mathrm{m}, 25 \mathrm{~m} . \mathrm{n}$ । $\mathrm{TFE}$; HPLC Millex), transferred into $100 \mathrm{~mL}$ HDPE bottles, acidified to $\mathrm{pH}<2$ (with ur rapuie $6 \mathrm{M} \mathrm{HCl}$ ) and sealed (Parafilm) until lab processing and analyses.

Tips of spires standing at th 2 shores of both lakes (Figs $1 \mathrm{~A}, \mathrm{~B} ; 2 \mathrm{~A}, \mathrm{~B}$ ) and close to the shoreline were sample.' ( $\mathrm{ne}$ from each lake) for investigations. We collected samples ( $4 \mathrm{~g})$ from the macroscopica ${ }^{1} \mathrm{v}$ different layers of the spires after cross-cutting them and using a diamond mini drill (Fig. 3 A,B). The spire samples along with those of basalt and salt were ground into fine powders in an agate mortar for further analyses. Thin polished sections from the same cross-sections were prepared for optical microscopy observations.

\section{Methods of investigation}

\subsection{Mineralogy investigations of the spires}


We investigated the mineralogy and texture of the spires (thin polished sections) with optical polarizing microscope (Eclipse LV100N POL, Nikon). After the observations of the thin sections in transmitted light and acquiring of photographs we stained the same thin sections with Feigl's solution (Friedman, 1959) in order to distinguish between aragonite and calcite and document the spatial relations between them.

The bulk mineralogy of the different internal layers of the spires was studied by X-ray diffractometry (XRD) (PANalytical B.V. X'Pert PRO MPD X-ray diffractometer with monochromatic $\mathrm{Cu} K_{\alpha}$ radiation, graphite monochromator, $45 \mathrm{kV}, 40 \mathrm{~mA}$ ) of random powder mounts: scans from 10 to $75^{\circ} 2 \theta$, with steps of $0.008^{\circ} 2 \theta$, at 10 step. Obtained XRD patterns were compared with established peak sets using X'Pert HighS ore Plus software to determine mineralogical composition of the samples. The amount of $\mathrm{Mg}_{2} \mathrm{O}_{3}$ (in mol. \%) in the calcite crystal lattice was calculated using $d_{104}$ values of the $X^{D n}+$ atterns recorded from 20 to $40{ }^{\circ} 2 \theta$, with steps of $0.02^{\circ} 2 \theta$, at $1.5 \mathrm{~s} / \mathrm{step}$ (Rigaku Ultima IV $\lambda$ - uy diffractometer with monochromatic $\mathrm{Cu} K_{\alpha}$ radiation, MacDiff software).

\subsection{Elemental concentrations measuremen ${ }^{\prime \prime}$ the spires, basalt and salt}

Major elements concentrations i. h hasalt and salt samples were measured by X-ray fluorescence (XRF) at the Geo ' gical Survey of Japan (GSJ) of the National Institute of Advanced Industrial Science and Technology (AIST) in Japan. For the XRF analysis glass beads were prepared by mixing 05 I of powdered sample with $5.0 \mathrm{~g}$ of lithium tetraborate flux. The mixture was heated to ${ }^{1} \mathrm{a}$ no - for $10 \mathrm{~min}$ in a $95 \%$ Pt-5\% Au crucible using a semi-automatic fusion device HAG-M-IIF (Herzog). Ten major elements $\left(\mathrm{SiO}_{2}, \mathrm{TiO}_{2}, \mathrm{Al}_{2} \mathrm{O}_{3}\right.$, total $\mathrm{Fe}_{2} \mathrm{O}_{3}, \mathrm{MnO}$, $\mathrm{MgO}, \mathrm{CaO}, \mathrm{Na}_{2} \mathrm{O}, \mathrm{K}_{2} \mathrm{O}$, and $\mathrm{P}_{2} \mathrm{O}_{5}$ ) were quantified by an X-ray fluorescence instrument $\mathrm{ZSX}$ Primus III+ (Rigaku) with an Rh tube. The calibration curves of each element were prepared using GSJ geochemical reference samples with their chemical compositions varying from mafic to felsic. The accuracy was verified each day using two GSJ geochemical reference samples: JB$1 \mathrm{~b}$ and JG-3. The analytical uncertainties for each element were better than $1.5 \%$, as estimated from the long-term reproducibility of the measurements of JB-1b (Morita et al., 2016; Damak et al., 2019). 
The concentrations of $\mathrm{Al}, \mathrm{Mg}$, Ti, P, Fe, Mn, Sr, Ba, Rb, Li, Cu, Co, Ni, V, Zn, Pb, Cd, Mo, Tl, Cr, W, Ga, Sc, Hf, Th, U, Y and rare earth elements (REE) in the spire, basalt and salt samples were measured by High Resolution-Inductively Coupled Plasma-Mass Spectrometry (HR-ICP-MS). Between 80 and $100 \mathrm{mg}$ of powdered samples were weighted in PTFE vials and dissolved using a mixture of $\mathrm{HF}_{-} \mathrm{HNO}_{3}$. The solutions were evaporated to dryness and redissolved in aqua regia. After evaporation, the residues were dissolved in $5 \mathrm{~mL} 6 \mathrm{M} \mathrm{HCl}$ for archiving. Splits of $100 \mu \mathrm{L}$ from the archive solutions were taken in HDPE vials and diluted in 5 $\mathrm{mL} \sim 0.28 \mathrm{M} \mathrm{HNO}_{3}$ for HR-ICP-MS measurements. Two geostandards (BHVO-2 and CAL-S) and a procedural blank were prepared along with the samples fur'wing the same dissolution protocol. Elemental concentrations in the sample solutions (in $-0.23 M \mathrm{HNO}_{3}$ ) were measured with a HR-ICP-MS Element XR (ThermoFisher Scientific) ‘t th ₹ Pôle de Spectrométrie Océan (PSO) (IUEM/Ifremer, Brest, France) using indium is $\eta_{1}$ internal standard for drift signal correction. Concentrations were calibrated using externa calibration standards prepared for the

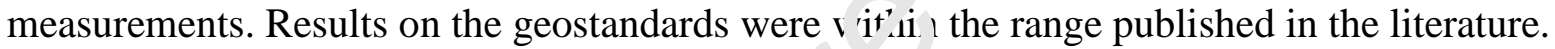

For Si concentrations measurements in in $\mathrm{s}_{\mathrm{r}}$ ires we processed the powdered spire samples following the protocol detailed in Raguenea e et al. (2005). This method transforms the silica into dissolved silica, permitting its analysis by a continuous flow auto-analyzer at a wavelength of 820 nm (SEAL-BRAN+LUEBBE AA3 HR auto-analyzer). The method used to analyze the Si concentration in the dissolved silic (spire and fluid samples) is based on the reaction of silicates with molybdate $(\mathrm{pH}=1.5)$ to .nn the $\beta$-silicomolybdic complex, which is reduced by ascorbic acid to form a blue comprad ':minot and Kérouel, 2007). We used a Si concentration standard (Certipur) ranging from $\left.\bigcap_{\llcorner}\right\lrcorner 0 \mu \mathrm{M}$ in an 18.2 $\mathrm{M} \Omega$ water based solution. The standard deviation of the analyses within thiu range was $\leq 0.5 \%$.

\subsection{Basic physical-chemical parameters of the fluids}

Temperature (T), $\mathrm{pH}$ and dissolved oxygen (DO) of the fluids were measured in situ immediately after sampling using electrodes (D-55; Horiba Ltd.). Alkalinity of the fluids was determined by titration with $0.05 \mathrm{~N} \mathrm{H}_{2} \mathrm{SO}_{4}$ (Bromocresol Green-Methyl Red method) within 5 hours after sampling. The fluid density was determined by weighing of constant-volume (100$200 \mu \mathrm{L})$ samples and $18.2 \mathrm{M} \Omega$ water $(10-20$ replicates $)$ at laboratory temperature $\left(\sim 22^{\circ} \mathrm{C}\right)$. 
Dissolved inorganic carbon (DIC) concentrations in the fluid samples were calculated with the computer program PHREEQC version 3 (Parkhurst and Appelo, 2013) using the measured fluid chemical composition, $\mathrm{pH}$ and temperature.

\subsection{Elemental concentrations measurement in the fluids}

\subsubsection{Major elements}

Major cations $\left(\mathrm{Na}^{+}, \mathrm{K}^{+}, \mathrm{Mg}^{2+}, \mathrm{Ca}^{2+}\right)$ and anions $\left(\mathrm{Cl}^{-}\right.$and $\left.\mathrm{SO}_{4}{ }^{2-}\right)$ concentrations in the fluids were measured using an ion chromatograph ICS-1600 (DIONE ${ }^{-}$). Bromide $\left(\mathrm{Br}^{-}\right)$and $\mathrm{NO}_{3}^{-}$ concentrations in the fluids were measured by a high-per orm ince liquid chromatograph according to the procedure described by Maruo et al. (2006).

Silicon concentrations in the fluids were analyzed foll $\sim / 1.9$ the method described in 4.2.

\subsubsection{Lithium and $\mathrm{Sr}$}

Lithium and $\mathrm{Sr}$ concentrations in the fluir $-\mathrm{w}$. re measured by quadrupole inductively coupled plasma mass spectrometry (ICP-MS) iCAY $\smile \cdot$ (ThermoFisher Scientific) at the Japan Agency for Marine-Earth Science and Technology. Prior to analysis by ICP-MS, the fluid samples were diluted in polypropylene vials, follow $\mathrm{e} \mathrm{L}, \mathrm{y}$ the addition of $0.3 \mathrm{M} \mathrm{HNO}_{3}$ (Tamapure AA-100) to each vial. To control for instrum nt ciift, internal standards for Be, Sc, Y, and In were used. Laboratory standard solution ware measured after every fifth sample for data correction purposes. The reproducibilitv $f$ he measurements of each element were better than 5\% ( $2 \mathrm{RSD}$ ), estimated by repeated i. ${ }^{\circ} \cdot{ }^{\prime} \cdot$ ments of standard solutions (Araoka and Yoshimura, 2019).

\subsubsection{Iron, $\mathrm{Mn}$, $\mathrm{Co}, \mathrm{Ni}, \mathrm{Cu}, \mathrm{Zn}, \mathrm{Cd}, \mathrm{Mo}, \mathrm{Pb}, \mathrm{Ag}, \mathrm{Sn}, \mathrm{U}, \mathrm{V}, \mathrm{Y}$ and $\mathrm{REE}$}

Since most of the studied fluid samples were highly saline a direct and simple analysis of the trace element chemistry was difficult. Therefore, a method for the determination of concentrations for a set of elements ( $\mathrm{Fe}, \mathrm{Mn}, \mathrm{Co}, \mathrm{Ni}, \mathrm{Cu}, \mathrm{Zn}, \mathrm{Cd}, \mathrm{Mo}, \mathrm{Pb}, \mathrm{Ag}, \mathrm{Sn}, \mathrm{U}, \mathrm{V}, \mathrm{Y}$ and REE) in the collected fluids was used by applying a separation procedure that adjusts the fluid sample $\mathrm{pH}$ to $\sim 6$ and applying a single preconcentration step (Sohrin et al., 2008; Minami et al., 2015). The elements were separated from $\sim 2 \mathrm{~mL}$ of fluid sample using a column filled with the NOBIAS Chelate-PA1 resin (with ethylenediaminetriacetic acid and iminodiacetic acid 
functional groups; Hitachi High-Technologies) and collected for concentration measurement with HR-ICP-MS. The procedure starts with preparation of a buffer with $\mathrm{pH} \sim 9$ by mixing $30 \mathrm{~g}$ of acetic acid, $70 \mathrm{~g}$ of $18.2 \mathrm{M} \Omega$ water, and $50 \mathrm{~g}$ of $20 \% \mathrm{NH}_{3}$ (Minami et al., 2015), which was used to adjust the samples to $\mathrm{pH} \sim 6$ prior to column purification. Then, the columns were loaded with $0.5 \mathrm{~mL}$ of clean NOBIAS Chelate-PA1 resin. The resin was rinsed with $30 \mathrm{~mL} 18.2 \mathrm{M} \Omega$ water, $0.5 \mathrm{~mL} 3 \mathrm{M} \mathrm{HNO}_{3}$, and $10 \mathrm{~mL} 18.2 \mathrm{M} \Omega$ water. Before the sample load the resin was conditioned with $1 \mathrm{~mL} 2.5 \% \mathrm{HNO}_{3}+120 \mu \mathrm{L}$ buffer at final $\mathrm{pH}$. The sample matrix was eluted with $10 \mathrm{~mL}$ 18.2 $\mathrm{M} \Omega$ water. Trace elements were eluted with $23 \mathrm{~mL} 3 M \mathrm{HNO}_{3}$. At the end the resin was rinsed with $20 \mathrm{~mL} 18.2 \mathrm{M} \Omega$ water and the columns stored for furthor s paration procedures.

The solutions with eluted trace elements were evaporated $t=\tau_{1}, \ldots$ ss and re-dissolved in $2 \mathrm{~mL}$ $\sim 0.28 \mathrm{M} \mathrm{HNO}_{3}$ for HR-ICP-MS measurements. Conce tra $^{4}{ }^{*}$ ns of trace elements in these solutions were measured with a HR-ICP-MS Element $\therefore R$ (ThermoFisher Scientific) at the PSO. Indium was used as an internal standard for correcting drit of the signal and concentrations were calibrated using external calibration standards. A referenced seawater standard (CASS-4; National Research Council, Canada) and wo bla.ks were also processed following the above protocol and analyzed with the same HR-ICr-MS instrument.

\subsubsection{Boron}

Boron concentrations in the fuic samples were determined following the analytical procedure of Cotten et al. (1995) at the P১ ? . Boron was measured by Inductively Coupled Plasma-Atomic Emission Spectrometry (IC?-AES) using a Horiba Jobin Yvon® Ultima 2 spectrometer. Calibrations were made 'sing the international standard CASS-6 (National Research Council Canada). The standard deviation on the standard was $\leq 5 \%$.

\subsection{Carbon and $O$ isotope analyses}

\subsubsection{Carbon and $O$ isotope analyses of the spires}

Carbon and oxygen stable isotope compositions of the spire samples were analyzed using an isotope ratio mass spectrometer (IsoPrime, GV Instruments Ldt.) with an automated carbonate reaction system (Multiprep). The $\delta^{13} \mathrm{C}$ and $\delta^{18} \mathrm{O}$ values are reported with respect to the Vienna Pee Dee Belemnite (VPDB) standard. Analytical errors (95\% probability) were estimated to be 
within $0.1 \%$ for both oxygen and carbon, based on repeated measurements of authentic (NBS-19; $\delta^{13} \mathrm{C}=+1.95 \%$ and $\delta^{18} \mathrm{O}=-2.20 \%$ ) and laboratory working standards.

\subsubsection{Carbon and $O$ isotope analyses of the fluids}

Fluid samples for $\mathrm{C}$ and $\mathrm{O}$ isotopic analysis were collected in $12 \mathrm{~mL}$ glass vials after filtering $(0.2 \mu \mathrm{m}$ pore-size filters, ADVANTEC). The vials were filled with fluid, sealed with a rubber stopper and an aluminum cap for preventing gas leakage.

The $\delta^{13} \mathrm{C}$ of dissolved inorganic carbon (hereafter notated as $\delta^{13} \mathrm{C}_{\mathrm{DIC}}$ ) and $\delta^{18} \mathrm{O}_{\mathrm{H} 2 \mathrm{O}}$ in the sampled fluids were measured with Finnigan MAT Delta Plu stable isotope ratio mass spectrometer accompanied by a Gas Bench. The $\mathrm{CO}_{2}$ was separ ted by gas chromatography and introduced into the mass spectrometer. For analyzing $\delta^{13} \mathrm{C}_{\mathrm{D}_{1}} \sim$ ar $d \delta^{18} \mathrm{O}_{\mathrm{H} 2 \mathrm{O}}, 0.3 \sim 0.6 \mathrm{~mL}$ of fluid sample were added to one drop of $\mathrm{H}_{3} \mathrm{PO}_{4}(\sim 0.02 \mathrm{~mL})$ ir $4.5 \mathrm{n}$ L glass vial, filled under $1 \mathrm{~atm} \mathrm{He}$ and kept at $25.0^{\circ} \mathrm{C}$ for three days to gain isotopic equilit. 'um. $\delta^{13} \mathrm{C}_{\mathrm{DIC}}$ and $\delta^{18} \mathrm{O}_{\mathrm{H} 2 \mathrm{O}}$ values were calculated with respect to the Vienna Pee Dee Pel mnite (VPDB) and VSMOW standards, respectively. Analytical precision of the lab $\mathrm{sc}^{\circ}{ }^{\circ} \mathrm{or}$, standard (HRS-dc) was $<0.2 \%$ ( $2 \sigma$; Hori et al. 2009). The reported $\delta^{13} \mathrm{C}_{\mathrm{DIC}}$ values were can 'lated from the measured $\delta^{13} \mathrm{C}_{\mathrm{DIC}}$ values by taking into account the amount of the remaining aqueous $\mathrm{CO}_{2}$. We used the isotopic equilibrium constant for gaseous and aqueous $\mathrm{CO}_{2}$ ('f' 'thang et al. (1995).

\subsection{Iron-Zn-isotope analyses}

\subsubsection{Iron-Zn-isotope $\mathrm{se}_{\text {, }}$ ar uilon from the spire samples}

Polypropylene colunıs (Kimble Chase) were filled with 2 mL AG MP-1M resin (100-200 mesh; chloride form) for Fe-Zn-isotope separation in two purification steps. In the first purification step, the resin was cleaned with $8 \mathrm{~mL} 3 M \mathrm{HNO}_{3}$ and $15 \mathrm{~mL} 18.2 \mathrm{M} \Omega$ water, and conditioned with $4 \mathrm{~mL} 6 \mathrm{M} \mathrm{HCl}$ before sample load. An aliquot from the $6 \mathrm{M} \mathrm{HCl}$ archive solution of the spire samples was collected for column load for Fe-Zn-isotope separation. Iron (along with $\mathrm{Cu}$ ) was eluted with $2.5 \mathrm{~mL} 6 \mathrm{M} \mathrm{HCl}, 10 \mathrm{~mL} 2 M \mathrm{HCl}$ and $4 \mathrm{~mL} 0.24 \mathrm{M} \mathrm{HCl}$ in 30 $\mathrm{mL}$ PTFE vials. The solutions were evaporated on hot $\left(90^{\circ} \mathrm{C}\right)$ plate to dryness, re-dissolved in 3 $\mathrm{mL} 6 \mathrm{M} \mathrm{HCl}$ and stored in $4 \mathrm{~mL} \mathrm{HDPE}$ tubes for further $\mathrm{Fe}$ from $\mathrm{Cu}$ isotope separation. Zinc was eluted from the same columns with $18 \mathrm{~mL} 0.012 \mathrm{M} \mathrm{HCl}$ in $23 \mathrm{~mL}$ PTFE vials. The solutions 
were evaporated on hot $\left(90^{\circ} \mathrm{C}\right)$ plate to dryness, re-dissolved in $\sim 0.28 \mathrm{MHNO}_{3}$ and transferred in HDPE tubes for MC-ICP-MS analysis.

In the second purification step, the same columns (with $2 \mathrm{~mL}$ AG MP-1M resin) were used for separation of $\mathrm{Fe}$ from $\mathrm{Cu}$ isotopes. The resin was cleaned with $8 \mathrm{~mL} 3 M \mathrm{HNO}_{3}$ and $15 \mathrm{~mL} 18.2$ $\mathrm{M} \Omega$ water, and conditioned with $4 \mathrm{~mL} 6 \mathrm{M} \mathrm{HCl}$ before sample load. After the sample load (in 3 $\mathrm{mL} 6 \mathrm{M} \mathrm{HCl}$ ) the matrix was eluted with $2 \mathrm{~mL} 6 \mathrm{M} \mathrm{HCl}$. Copper was eluted with $50 \mathrm{~mL} 6 \mathrm{M} \mathrm{HCl}$ in $30 \mathrm{~mL}$ PTFE vials and archived in $50 \mathrm{~mL}$ centrifuge tubes. From the same columns, Fe was eluted with $12.5 \mathrm{~mL} 0.24 \mathrm{M} \mathrm{HCl}$ in $30 \mathrm{~mL}$ PTFE vials, evaporated on hot $\left(90^{\circ} \mathrm{C}\right)$ plate to dryness, re-dissolved in $\sim 0.28 \mathrm{MHNO}_{3}$ and transferred in tubes for MC-ICF-1, ${ }^{\top} \mathrm{S}$ analysis.

\subsubsection{Iron-Zn-isotope separation from the fluid samples}

Fluid samples for Fe-Zn-isotope analysis were $\operatorname{se}^{1} \boldsymbol{c}^{\prime a}$ on the basis of their Fe and $\mathrm{Zn}$ concentrations measured by HR-ICP-MS. The samples $w \cdot h$ low Fe and $\mathrm{Zn}$ concentrations $(<10$ $\mathrm{ppb}$ ) were not processed for isotope separation anc v el z not analyzed for isotopic compositions.

Aliquots from the fluid samples were tak $\_$in $n$.TFE vials and adjusted to $\mathrm{pH} \sim 6$ with the $\mathrm{pH} \sim 6$ buffer (see above). The samples were first, 'lrified from the saline matrix and preconcentrated using the NOBIAS Chelate-PA1 resin tc'1owing the protocol described above. Preconcentrated samples were then processed through rol ımns filled with AG MP-1M resin following the same procedure described above for th ${ }_{L_{1}}$ nire samples for separation of the isotopes of Fe and $\mathrm{Zn}$.

\subsubsection{Iron-Zn isotope mer s. "er...ents}

Iron and $\mathrm{Zn}$ isotopes in spire and fluid samples were measured on a MC-ICP-MS Neptune (ThermoFisher Scientifiu, at the PSO. Zinc isotope composition was analyzed in low resolution mode using a cyclonic spray chamber as the introduction system. The instrumental mass bias for $\mathrm{Zn}$ isotopes was corrected by addition of Cu NIST SRM-3114 standard to samples (Marechal et al., 1999). ${ }^{66} \mathrm{Zn} /{ }^{64} \mathrm{Zn}$ ratios are reported according to the conventional delta notation (equation 1) using Zn NIST SRM-683 as reference standard for Zn isotope ratio:

$$
\delta^{66 / 64} \mathrm{Zn}=\left[\left({ }^{66} \mathrm{Zn} /{ }^{64} \mathrm{Zn}\right)_{\text {sample }} /\left({ }^{66} \mathrm{Zn} /{ }^{64} \mathrm{Zn}\right)_{\mathrm{SRM} 683}-1\right] \times 1000
$$


All data from the literature used for comparison in this study were recalculated against the NIST SRM-683 standard.

Iron isotope compositions were measured in high resolution mode and samples were introduced in the plasma with a cyclonic spray chamber. Nickel addition to the samples was used for correcting the instrumental fractionation during the analysis. ${ }^{56} \mathrm{Fe} /{ }^{54} \mathrm{Fe}$ ratios are reported relative to IRMM-14 according to the conventional delta notation (equation 2) used for stable isotope systematics:

$$
\delta^{56 / 54} \mathrm{Fe}=\left[\left({ }^{56} \mathrm{Fe} /{ }^{54} \mathrm{Fe}\right)_{\text {sample }} /\left({ }^{56} \mathrm{Fe} /{ }^{54} \mathrm{Fe}\right)_{\mathrm{IRMM}-14}-1\right] \times 1000
$$

All data from the literature used for comparison in this s'uds were recalculated against the IRMM-14 standard.

A standard-sample-bracketing scheme was emplovei tor the two isotope system ( $\mathrm{Fe}, \mathrm{Zn}$ ) measurements and the USGS Certified Reference Na aerial BHVO-2 was processed through the columns and analyzed along with the samp ${ }^{1}-t_{0^{1}}$ owing the same protocols for comparison with the published values. The typical two-stana. d deviation on bracketing standards was $0.07 \%$ for $\mathrm{Zn}$ isotope values and $0.07 \%$ for $\mathrm{Fe}$ isot, $\mathrm{p}_{1}$ values.

\subsection{Uranium-Th age dating of the vires}

The chemical procedur $f_{0}: \mathrm{J}$-Th age dating of carbonate spires followed that described in Bayon et al. (2015). tho $15 \mathrm{mg}$ of powdered sample were put in pre-cleaned PTFE vials

together with a mixed ${ }^{23} \mathrm{U}_{-}{ }^{229} \mathrm{Th}$ spike, and digested on hotplate with $7.5 M \mathrm{HNO}_{3}$. After evaporation, each sample was taken up in diluted $\mathrm{HNO}_{3}$ prior to addition of ultrapure Fe solution and ammonia to induce Fe-oxide co-precipitation. The resulting Fe-oxides were centrifuged, rinsed in ultrapure water, and further dissolved in $7.5 \mathrm{M} \mathrm{HNO}_{3}$. Finally, $\mathrm{U}$ and Th were separated using conventional anion exchange techniques. Uranium and Th concentrations and isotope ratios were measured with a MC-ICP-MS Neptune (ThermoFisher Scientific) at the PSO, using a standard-bracketing measurement protocol with IRMM-184 (U) and IRMM-036 (Th) reference solutions, respectively. U-Th carbonate age calculation was performed by the isochron method using the Isoplot/Ex program (version 4.15; Ludwig, 2011) in order to correct measured ratios 
from detrital contamination. The mean isochron age was determined using theoretical endmember at the secular equilibrium (activity ratios $=1.0 \pm 0.5$ ).

\subsection{Strontium isotope analysis}

About $20 \mathrm{mg}$ powdered spire samples were dissolved in $3 \mathrm{MHNO}_{3}$, prior to separation using $\mathrm{Sr}$ resin (Eichrom). Strontium isotopic ratios were determined by MC-ICP-MS Neptune (ThermoFisher Scientific) at the PSO. Measured ${ }^{87} \mathrm{Sr} /{ }^{86} \mathrm{Sr}$ ratios were normalized to NIST SRM-987 standard solutions. Repeated Sr isotopic analyses of NiT SRM-987 solutions were associated with an uncertainty of 0.000016 (2SD), taken as the external reproducibility of measured ${ }^{87} \mathrm{Sr} /{ }^{86} \mathrm{Sr}$ ratios. The analysis of a solution of $\mathrm{B} \cdot \mathrm{TV}(-2$ certified reference material $(0.703470 \pm 0.000009)$ agreed well with the recommend $-d v_{i} \cdot$ lue $(0.703481 \pm 0.000020)$ of Weis et al. (2005).

The $\mathrm{Sr}$ isotopic composition of the fluid sal $\mathrm{p}^{\prime} \mathrm{e}$; was determined following a procedure reported by Yoshimura et al. (2018) and A 1 as and Yoshimura (2019). We used an offline method for the purification of $\mathrm{Sr}$ with ion $\iota^{2}$ iomatograph (IC) coupled to an automated fraction collector prior to stable isotope measurt. nents. Samples were introduced into IC on a Metrohm 930 Compact IC Flex (Metrohm AG) ir st ument coupled to an Agilent 1260 Infinity II Bio-Inert analytical-scale FC system (Agile. $\mathrm{t}$ Tt.hnologies). Then, they were loaded in $0.8 \mathrm{mM}$ ultrapure $\mathrm{HNO}_{3}$ acid (Tamapure AA-10? '? ma Chemicals) and passed through a Metrohm Metrosep C6260/4.0 column at a flow rate of $0.9 \mathrm{~mL} / \mathrm{min}$. The purified samples were pooled in $7 \mathrm{~mL}$ PTFE vials, then dried out. Thu d. ed residue was dissolved in $0.3 \mathrm{M}$ ultrapure $\mathrm{HNO}_{3}$ for isotope analysis. We also conc"w, ced the separation procedure in a class-1000 clean bench, to avoid contamination.

Strontium isotope ratios were measured by MC-ICP-MS Neptune Plus (ThermoFisher Scientific) at the GSJ, AIST. Instrumental mass fractionation was calibrated by ${ }^{88} \mathrm{Sr} /{ }^{86} \mathrm{Sr}$ ratio of 8.3752, followed by a standard-sample bracketing method using NIST SRM-987. The reproducibility of multiple measurements of purified $\mathrm{Sr}$ solution from IAPSO seawater standard by this IC-FC system during each analytical session: $0.70917 \pm 0.00003(2 \mathrm{SD}, \mathrm{n}=11)$ (Araoka and Yoshimura, 2019), which agrees well with the reported values of $0.709169 \pm 0.000029$ (2SD, $\mathrm{n}=5$ ) (Liu et al., 2012). 


\subsection{Calcium isotope analysis}

For $\mathrm{Ca}$ isotope analyses $\sim 20 \mathrm{mg}$ of the powdered samples from the Lake Asal spire were dissolved in $2.25 \mathrm{M} \mathrm{HNO}_{3}$ at room temperature. All chemical preparations were done in a laminar flow bench within clean lab facilities using acids purified by a 2-step Teflon cascade still. After no remaining residues could be observed, aliquots of $1500 \mathrm{ng} \mathrm{Ca}$ equivalent of these solutions as well as of hydrothermal fluid and of lake water were mixed with a ${ }^{43} \mathrm{Ca} /{ }^{48} \mathrm{Ca}$ double spike and evaporated. The samples were treated with a mixture of $\imath 75 \mathrm{~mL} 8 M \mathrm{HNO}_{3}$ and 0.25 $\mathrm{mL} \mathrm{H}_{2} \mathrm{O}_{2}$ for at least $12 \mathrm{~h}$ at $80^{\circ} \mathrm{C}$ to disintegrate potentially $\mathrm{Ca}$ suri ication hampering organics. After evaporation to dryness at $80^{\circ} \mathrm{C}$ and re-suspension in $2.2 Y \mathrm{HNO}_{3}$ at room temperature, procedures for $\mathrm{Ca}$ extraction with $\mathrm{MCI}-\mathrm{Gel}$, isotope mt. surement with a Finnigan Triton Thermal Ionisation Mass Spectrometer (TIMS), and data - uuction were followed as described by Heuser et al. (2002) and Böhm et al. (2006).

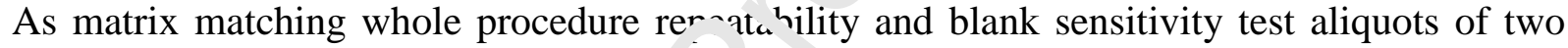
samples (Site 3 vent and Lake Abhé site :`) were also processed on half Ca amount (750 ng equivalent). The results for these additı al samples showed within uncertainties identical mean values when compared to their doubl $-r \mathrm{Z} \mathrm{Z}-\mathrm{d}$ routine equivalents (differences of mean values 0.03 and $0.04 \%$, respectively). With $\mathrm{k}$ : -ping identical, or very similar uncertainties (95\% confidence level) this small sample dupl aa approach implies adequate repeatability, method robustness and no significant blank contriv. ion (typical below $50 \mathrm{ng}$ Ca for this method and facility).

Each sample run the $M_{\zeta} h$ t.1e clean-lab procedures described above was measured 3 to 7 times (indicated as " $\mathrm{n}$ ") and ar of these measurements was performed on its own filament. The accuracy of the reported mean results is supported by distributing the measurements on at least two of seven different and independent TIMS sessions involved in this study. These sessions were individually normalized on the session specific mean of NIST SRM-915a measurement sets $(\mathrm{n}=3)$, which were operated similarly to the samples by running each measurement on own and originally loaded filament from one source solution. The NIST SRM-915a repeatability was \pm $0.2 \%$ o $\left(95 \%\right.$ confidence level, $\left.\mathrm{n}_{\text {sessions }}=7\right)$, typical for this method and measurement facility. Based on increased "n" values all samples analyzed during the course of the study reached repeatability better than this limit. 
Isotope data are reported as $\delta^{44 / 40} \mathrm{Ca}(\%)$ relative to the NIST standard SRM-915a, where:

$$
\delta^{44 / 40} \mathrm{Ca}=\left[\left({ }^{44} \mathrm{Ca} /{ }^{40} \mathrm{Ca}\right)_{\text {sample }} /\left({ }^{44} \mathrm{Ca} /{ }^{40} \mathrm{Ca}\right)_{\mathrm{SRM}-915 \mathrm{a}}-1\right] \times 1000
$$

All Ca isotope data from the literature used for comparison in this work was converted relative to the NIST standard SRM-915a.

\subsection{Sulfur isotope analysis of the fluids}

Sulfur isotope composition of $\mathrm{SO}_{4}{ }^{2-}$ in the fluids was $a \eta_{\mathbf{a}}{ }^{1}$ vzed after $\mathrm{SO}_{4}{ }^{2-}$ recovery as $\mathrm{BaSO}_{4}$ precipitated upon adding $0.5 \mathrm{M} \mathrm{BaCl}$ solution in the amples. Sulfur isotope ratio of the precipitate was measured using a continuous-flow $m_{\Lambda}$ ss-spectrometer with an elemental analyzer IsoPrime EA (GV Instruments). Sulfur isotene ralues are reported using the common notation, $\delta^{34} \mathrm{~S}$, per mil deviation relative to the intern. ${ }^{\text {i }}$ snal standard Canyon Diablo Troilite (CDT).

\section{Results}

\subsection{Mineralogy of the spires}

The spire from Lak. A al ,LAs) is composed of low-Mg calcite and aragonite (Table 2). The different layers of the sni e wall (Fig. 3 A) are composed of different proportions of these two minerals. In the central zone (LAs-3) low-Mg calcite dominates over aragonite, whereas in the outer layers (LAs-2 and -1) aragonite content is close to that of low-Mg calcite (Table 2). The low-Mg calcite crystals in the central zone (LAs-3) are concentrically zoned (Fig. 4 A,B). At the transition between the low-Mg calcite dominated central zone (LAs-3) and the next layer where low-Mg calcite and aragonite are in comparable proportions (LAs-2) the low-Mg calcite crystals are overgrown by needle-like aragonite crystals, which in turn are coated by low-Mg calcite (Fig. 4 C,D). The outer layers (LAs-2 and -1) of the spire are composed of botryoids of needle-like aragonite overgrown by low-Mg calcite (Fig. 4 E,F,G,H). 
The spire from Lake Abhé (LAb) is composed of low-Mg calcite and high-Mg calcite (Table 2). Different proportions of these calcite varieties compose the layers of the spire wall (Fig. 3 B). In general, most of the internal layers (around the central zone) are low-Mg calcite dominated, whereas the external layers are high-Mg calcite dominated (Table 2). The high-Mg calcite dominated layers have botryoidal surface composed of fine radial high-Mg calcite crystals (Fig. 5 $\mathrm{A}, \mathrm{B})$. The low-Mg calcite dominated layers are composed of skeletal low-Mg calcite crystals (Fig. 5 C,D).

Salt from the salt plain of Lake Asal is composed of halite and traces of gypsum (Table 2).

\subsection{Chemical composition of the spires}

Trace element concentrations in the carbonate spire f- $\sim \eta_{1}$ Lake Asal (LAs) increase from the innermost (central) zone towards the outermost zone (la, ${ }_{i}$ ) (Table 3). The total amount of the REE ( REE) also increases from the innermost $t$ r the outermost zone (Table 3). The PostArchean Australian Shale-normalized (PAA n - nalized) REE distribution patterns of the spire layers are similar to that of the local basalt ${ }^{\top}$ As-basalt): they show no $\mathrm{Ce}$ anomaly $\left(\mathrm{Ce} / \mathrm{Ce}^{*} \sim 1\right)$, positive Eu anomaly $\left(\mathrm{Eu} / \mathrm{Eu}^{*}>1\right)$ and $u \cdot$ nletion in the light $\mathrm{REE}$ in respect to the heavy REE $\left(\right.$ LapaAsN $\left./ L_{\text {PaAsN }}<1\right)$ (Table 3; Fig. 6 A ). The positive Eu anomaly decreases from the innermost to the outermost zone (Table 3).

Most trace element ( $\mathrm{Si}, \mathrm{Mg}, \mathrm{r}, \mathrm{Mn}, \mathrm{Sr}, \mathrm{Ba}, \mathrm{Li}, \mathrm{Ni}, \mathrm{V}, \mathrm{Pb}, \mathrm{Cr}$, Th, Y and REE) concentrations in the carbonate spire frnm Iake Abhé (LAb) show a clear correlation with spire layer mineralogy: higher con en tons are observed in the high-Mg calcite layers (LAb-3, -5, -6, -7, 8) compared to the low N"g calcite layers (LAb-1, -2, -4) (Table 3). Low-Mg calcite layers have higher both positive $\mathrm{Ce}\left(\mathrm{Ce} / \mathrm{Ce}^{*}>1\right)$ and positive $\mathrm{Eu}\left(\mathrm{Eu} / \mathrm{Eu}^{*}>1\right)$ anomalies, and are more depleted in the light REE relative to the heavy REE than the high-Mg calcite layers (Table 3; Fig. 6 B). Aluminum, Ti, Fe, Rb, Mo, Ga, U, Cu, Co and $\mathrm{Zn}$ do not demonstrate clear dependence on the mineralogy of the spire layers (Table 3).

The major element concentrations in the studied Asal Rift basalt (Table 4) are similar to those previously reported for the local basalts (Barrat et al., 1993). Using the major element composition (Table 4) and bulk mineralogy (Table 2) of the salt from the Lake Asal salt plain we 
estimated that in addition to the halite $(\mathrm{NaCl})$ and gypsum $\left(\mathrm{CaSO}_{4} \cdot 2 \mathrm{H}_{2} \mathrm{O}\right)$ the salt precipitated at the Lake Asal bottom contains also $\mathrm{MgCl}_{2}$ and $\mathrm{KCl}$ (Table 4).

\subsection{Chemical composition of the fluids}

Previous studies suggested genetic relations among the seawater in the Ghoubbet-al-Kharab, hydrothermal fluids in the Asal Rift and Lake Asal water (Bäcker et al., 1973; Gasse and Fontes, 1989; Sanjuan et al., 1990; D'Amore et al., 1998), therefore, we will compare the elemental concentrations in these three fluid types. Relationship betwec. the lake water and local hydrothermal fluids was inferred for Lake Abhé (Dekov et al., '01<) and thus, the chemistry of these two fluids are also compared.

Sodium, $\mathrm{SO}_{4}, \mathrm{~K}$ and $\mathrm{Mg}$ have the lowest concentration 1 the hydrothermal fluids, then in the seawater and the highest concentrations in the Lake Asai "ater (Table 5). Their contents show a similar increase from the hydrothermal fluid to $\mathrm{L}$ k - Abhé water (Table 5). Chlorine content is the lowest in the seawater and the highest : th: Lake Asal water (hydrothermal fluid being in between) and similar concentration trend is ${ }^{f}$ sund in the Lake Abhé system as well: lower in the hydrothermal fluid and higher in the : $\mathrm{ke}$ water (Table 5). Calcium shows another type of concentration gradation: lowest in the $e^{2}$ water and highest in the Lake Asal hydrothermal fluid (Lake Asal water being in betwee:) (lower in the lake water and higher in the hydrothermal fluid at the Lake Abhé) (Table 5). A : imilar increase (low in the Lake Asal water and high in the hydrothermal fluid) can be nb ${ }^{\circ}$ r $/$ ed for $\mathrm{Si}$ and $\mathrm{NO}_{3}$ conventrations, whereas the concentration of $\mathrm{Br}$ demonstrates an $\mathrm{O}_{\mathrm{L}} \mathrm{O}_{\mathrm{L}}$ ite trend (low in the hydrothermal fluid and high in the Lake Asal water) (Table 5).

Iron, $\mathrm{Mo}, \mathrm{V}, \mathrm{Ag}, \mathrm{Cd}$ and $\mathrm{La}$ have higher concentrations in the hydrothermal fluids jetting around Lake Asal than in the Lake Asal water (Table 5). Manganese, $\mathrm{Cu}, \mathrm{Zn}, \mathrm{Co}, \mathrm{U}, \mathrm{Sn}, \mathrm{Pb}, \mathrm{Li}$, $\mathrm{Sr}, \mathrm{Y}, \mathrm{Pr}$ and Nd show higher contents in the Lake Asal water than in the hydrothermal fluids (Table 5). Particularly high enrichment in the lake water relative to the hydrothermal fluid show $\mathrm{Zn}, \mathrm{U}$ and $\mathrm{Mn}$. Lithium is very high in both fluids. Nickel, Ce and Sm are in relatively similar amounts in both Lake Asal water and hydrothermal fluids (Table 5).

Generally speaking, Lake Abhé hydrothermal fluid has higher $\mathrm{Li}$ and $\mathrm{Sr}$ content, whereas Lake Abhé water has higher $\mathrm{Fe}, \mathrm{Mn}, \mathrm{Cu}, \mathrm{Ni}, \mathrm{Co}, \mathrm{Pb}, \mathrm{Y}$ and REE content (Table 5). Notably, 
Lake Abhé water is strongly enriched in $\mathrm{Fe}, \mathrm{Ni}$ and REE when compared to the hydrothermal fluid (Table 5). Both the Lake Abhé water and hydrothermal fluid contain similar amounts of $\mathrm{Zn}$ and Sn.

Vertical distributions of $\mathrm{pH}, \mathrm{T}$, alkalinity, and concentrations of major and trace elements across the Lake Asal water body were investigated in detail along one vertical profile, C1 (Fig. 7; Tables 1, 5). As a reference sample we have considered the hydrothermal fluid (3-nov) jetting at Site 3 and emptying in the lake. According to the vertical distributions of these physical and chemical parameters the lake water body can be divided in bottom, intermediate and surface zones at this site (Fig. 7). The bottom water ( 15-23 m depth) has 'ow pH (6.5-6.6), elevated T $\left(27-28^{\circ} \mathrm{C}\right)$, high alkalinity, low concentrations of $\mathrm{Cl}^{-}, \mathrm{SO}^{2-}, \mathrm{V}, \mathrm{Ni}$ and $\mathrm{Co}$, and high concentrations of $\mathrm{Br}^{-}, \mathrm{NO}_{3}{ }^{-}, \mathrm{Zn}, \mathrm{Cu}, \mathrm{Mn}, \mathrm{Sn}, \mathrm{Ag}, \mathrm{Pb}, \mathrm{U}$, Io nd $\mathrm{Si}$ (Fig. 7). The prominent features of the intermediate water $\left(\sim 10 \mathrm{~m}\right.$ depth) are an $\sim^{1}{ }^{\circ} \mathrm{v}_{c}$ ted $\mathrm{pH}(\sim 6.9)$, temperature $\left(\sim 25^{\circ} \mathrm{C}\right)$ lower than that in the other two water zones, and the low - Mn and highest Mo contents (Fig. 7). The surface water (0-5 m depth) has high $\mathrm{T}\left(\sim 27^{\circ}(-)\right)$ lnw alkalinity, the highest concentrations of $\mathrm{Cl}^{-}, \mathrm{SO}_{4}{ }^{2-}, \mathrm{Fe}, \mathrm{Mn}, \mathrm{V}, \mathrm{Ni}$ and $\mathrm{Co}$, and the $\mathrm{J}^{-\cdots} \mathrm{es}^{\circ}$ concentrations of $\mathrm{Zn}, \mathrm{Sn}, \mathrm{Ag}, \mathrm{Mo}$ and $\mathrm{Si}$ (Fig. 7).

The REE concentrations in the Lake $f$. sal water and hydrothermal fluids are very low: medium (Eu - Dy) and heavy (Ho - Lu) REF a - below the limits of detection (Table 5). The REE concentrations are also very low $\eta$ thi Lake Abhé hydrothermal fluids, but in the Lake Abhé water they showed measura'le contents (Table 5). Therefore, at the fragmentary PAASnormalized REE distribution ${ }^{\text {tt }}$ erns of the Lake Asal waters we can only see the weak negative $\mathrm{Ce}$ anomaly $\left(\mathrm{Ce} / \mathrm{Ce}^{*}-1,{ }^{*} \mathrm{~d}\right.$ a hint for no fractionation between the light and heavy $\mathrm{REE}$ (LapAAsN $/ \operatorname{Lu}_{\text {PAASN }}$ 1) (Trr 1 e 5; Fig. 6 C). The PAAS-normalized REE distribution pattern of the Lake Abhé water shows a well-pronounced positive Ce anomaly $\left(\mathrm{Ce} / \mathrm{Ce} e^{*}>1\right)$, a weak positive Eu anomaly $\left(\mathrm{Eu} / \mathrm{Eu}^{*}>1\right)$ and depletion in the light $\mathrm{REE}$ in respect to the heavy REE (LapaAsN $\left./ \mathrm{Lu}_{\mathrm{PAASN}}<1\right)$ (Table 5; Fig. 6 C).

\subsection{Isotope composition of the spires}

U-Th age dating of the studied spires shows that their most internal (central) zones are the oldest zones and the age of the different zones (layers) decreases outwards (Table 6). 
The stable isotope composition of the different layers of Lake Asal spire (LAs) is a linear function of the age of the layers: $\delta^{13} \mathrm{C}, \delta^{18} \mathrm{O}, \delta^{44} \mathrm{Ca}, \delta^{56} \mathrm{Fe}$ and $\delta^{66} \mathrm{Zn}$ become heavier with decreasing age (Table 6). Strontium isotope ratio $\left({ }^{87} \mathrm{Sr} /{ }^{86} \mathrm{Sr}\right.$ ) decreases (becomes less radiogenic) in the same direction (Table 6). Measured ${ }^{87} \mathrm{Sr} /{ }^{86} \mathrm{Sr}$ ratio of the local basalts (Table 6) is similar to that measured in previous works (Barberi et al., 1980).

Carbon, $\mathrm{O}, \mathrm{Fe}$ and $\mathrm{Sr}$ isotope compositions of the Lake Abhé spire (LAb) show correlations with the mineralogy of the spire layers. $\delta^{13} \mathrm{C}$ and $\delta^{18} \mathrm{O}$ are heavier, $\delta^{56} \mathrm{Fe}$ is lighter, and ${ }^{87} \mathrm{Sr} /{ }^{86} \mathrm{Sr}$ is more radiogenic in the high-Mg calcite layers than in the low-Mg calcite layers (Table 6).

\subsection{Isotope composition of the fluids}

The hydrothermal fluids jetting around Lake Asal (sa.nple 3-nov) have light $\mathrm{C}$ isotope composition $\left(\delta^{13} \mathrm{C}=-2.73 \%\right.$ ) close to that of the local - uwater $\left(\delta^{13} \mathrm{C}=-2.89 \%\right.$ ) (Table 7). In contrast, Lake Asal water has heavy $\mathrm{C}$ isotope c or $\mathrm{r}$ osition $\left(\delta^{13} \mathrm{C}>6 \%\right.$ ) that varies across the lake water body (Table 7; Fig. 7). A similar ${ }^{+}$re. $\mathrm{d}$ is observable in Lake Abhé: light $\delta^{13} \mathrm{C}$ in the hydrothermal fluids and heavier (although $\mathrm{st}$ reaching positive $\delta^{13} \mathrm{C}$ values) in the lake water (Table 7).

Oxygen isotope composition of the $s$ a water collected in Ghoubbet-al-Kharab $\left(\delta^{18} \mathrm{O}=0.85 \%\right.$; Table 7) is within the $\delta^{18} \mathrm{O}$ range neas ured in the surface seawater in the adjacent Gulf of Aden $\left(\delta^{18} \mathrm{O}=0.5-1.0 \%\right.$; Schmidt $\mathrm{c}^{+}$a., 1999$)$. The hydrothermal fluids discharging around Lake Asal have $\mathrm{O}$ isotope composition $\mathrm{n}$ a $/$ ier than that of the neighbor seawater $\left(\delta^{18} \mathrm{O}_{3 \text {-nov }}=2.79 \%\right.$ ), but lighter than the $\mathrm{O}$ iso $n_{\mathrm{c}} \mathrm{r}$ mposition of the Lake Asal water $\left(\delta^{18} \mathrm{O}>4 \%\right.$ ) (Table 7). Water close to the Lake Asal ' $r$.tom has $\delta^{18} \mathrm{O}$ lighter than that of the intermediate and surface waters (Fig. 7). The negative $\delta^{18} \mathrm{O}$ values of the hydrothermal fluids jetting around Lake Abhé (Table 7) are similar to those of the groundwater from the lower Awash River (Bretzler et al., 2011) that feeds the lake. The Lake Abhé water has positive $\delta^{18} \mathrm{O}$ values (Table 7).

Sulfur isotope composition of sulfate in the Lake Asal hydrothermal fluids (Table 7) is between those of the terrestrial mantle $(-0.91 \pm 0.50 \%$; Labidi et al., 2012) and seawater (20.97\%; Paris et al., 2013). The seawater from the Ghoubbet-al-Kharab has $\delta^{34} S$ very close to that of the mean seawater value (Table 7). Sulfur isotope composition (sulfate) of the Lake Asal water varies 
between 19.0 and $19.6 \%$ with the lightest values at the lake bottom and heaviest at the lake surface (Fig. 7; Table 7).

$\delta^{44} \mathrm{Ca}$ of the mean seawater standard (IAPSO) showed a value $(1.85 \pm 0.09 \%$, SE, $\mathrm{n}=9$; Table 7 ) in accord with published average seawater value (1.92\%; Fantle and Tipper, 2014). Calcium isotope composition of the Lake Asal hydrothermal fluids (0.92\%; Table 7) is within the range of the $\mathrm{Ca}$ isotope composition of the seafloor hydrothermal fluids [0.72 - 1.92\%; Amini et al. (2008), Scheuermann et al. (2018)] and close to that of the seafloor end-member hydrothermal fluid [0.88\%; Amini et al. (2008), Scheuermann et al. (2018)]. Hydrothermal fluids from Lake Abhé tend to even lighter $\mathrm{Ca}$ isotope composition (0.74-0.93\%; '. ' hle 7) similar to the one we measured earlier [0.90\%; Dekov et al. (2014)]. Calcium isotop a cr mposition of the Lake Asal water (1.22-1.64\%; Table 7) is significantly heavier than $\mathrm{t}$. at ( $\mathrm{f}$ the local hydrothermal fluids and approaches the seawater isotope composition. The $\mathrm{h} r \mathrm{v} / \mathrm{h}$ st isotope values are observed close to the lake floor whereas the lightest values are below th، '.uke surface (Fig. 7). Lake Abhé water has heavier $\mathrm{Ca}$ isotope composition (2.84\%o) tha $1^{\mathrm{f}} \mathrm{i}^{\circ}$ Lake Asal (Table 7) and slightly lighter than the previously measured [3.45\% ; Dekn at .1. (2014)]. However, it is distinctly heavier than the $\mathrm{Ca}$ isotope composition of river water ( $(-1.7 \%$; Fantle and Tipper, 2014).

Zinc isotope composition of the Lan Asal water is mostly negative ranging from -0.15 to $0.02 \%$ o $\left(\delta^{66} \mathrm{Zn}\right)$ (Table 7). The lighte $\mathrm{t}^{-6} \mathrm{Zn}$ values are observed close to the lake bottom and $\delta^{66} \mathrm{Zn}$ increases towards the lake irface (Fig. 7). The only hydrothermal fluid in which we were able to measure the $\mathrm{Zn}$ isotopc co.nposition was from a hot spring at the Lake Abhé shore which had $\delta^{66} \mathrm{Zn}=0.26 \%$ (Table 7 ). $\delta^{6} \mathrm{Zn}$ of the Lake Asal water (Table 7) is at the lighter end of the $\delta^{66} \mathrm{Zn}$ range of both $\mathrm{t}_{1}{ }^{2} \cdot{ }^{\wedge}{ }^{\circ}$ oor hydrothermal fluids $(-0.12-+1.21 \%$; John et al., 2008) and seafloor sulfides $(-0.21\lrcorner 1.05 \%$; John et al., 2008).

Lake Asal hydrothermal fluid has ${ }^{87} \mathrm{Sr} /{ }^{86} \mathrm{Sr}$ ratio similar to that of the Asal Rift basalt (Tables 6, 7). Lake Asal water has more radiogenic Sr isotope composition than the hydrothermal fluid, but it is less radiogenic than the seawater (Table 7). ${ }^{87} \mathrm{Sr} /{ }^{86} \mathrm{Sr}$ ratio is the lowest close to the lake bottom and slightly increases upward to the lake surface (Fig. 7). Hydrothermal fluids jetting at the Lake Abhé shore have Sr isotope composition (Table 7) close to that of the local basalts (Dama Ale volcano; Barberi et al., 1980). Strontium isotope composition of the Lake Abhé water (Table 7) is close to that of the Awash River (Bretzler et al., 2011), which feeds the lake. 


\section{Discussion}

\subsection{Lake Asal: a lake fed by seafloor-type hydrothermal fluids}

A lake located in tropical arid zone with scarce rainfall and with apparent lack of riverine water supply from distant wet zones will always provoke the question about its water source. The hypothesis that Lake Asal [a tropical-arid lake with no river supply; Gasse and Fontes (1989)] receives its water from the ocean (via Ghoubbet-al-Kharab) through fissures and faults was suggested long ago (Bäcker et al., 1973) and investigated to some extent recently (Boschetti et al., 2018). In a study of the Holocene ( $10-0$ kyr B.P.) palaeohydrology of the lake, Gasse and Fontes (1989) suggested that the strong water level fluctuations (fru $?+160$ to $-150 \mathrm{~m}$ ) in the lake have been controlled by both climate and water source changes. The hypothesized that the fresh groundwater from the Awash River system and seawater fro $\eta$ th : neighbor ocean have been the major sources of water to the lake and either of them $h^{2}-\mathrm{q} u$ minated over different stages of the lake history: e.g., fresh groundwater had dominated betw $\sim 11 \sim 8.6$ and 6 kyr B.P., while seawater has dominated between $\sim 5$ and $0 \mathrm{kyr}$ B.P.. Tr ei conclusions relied on indirect geological evidence and climatic mass-balance calculat: $\sim$ s. Although Gasse and Fontes (1989) inferred the seawater was one of the major components if the Lake Asal water, their work implied that this component was comparable with the fre $h$ groundwater input. The seawater supply was regarded as an infiltration (seemingly in physic $\mathrm{a}^{1} \mathrm{st}$.1se) through the rocks between the ocean and the lake without any water-rock interactioi. and elated consequences for the lake water chemistry.

Although we cannot comp! te $e^{\prime}$ rule out fresh groundwater supply to the Lake Asal (there is no riverine input and the rain. ${ }^{2} 11$ is scarce) our data show that this possible water component is negligible in Recent tu ne. T'e strong evaporation of a lake water body dominated by a fresh water component would $r$ sult in a saline, but basic lake $(\mathrm{pH}>7)$, similar to what is observed for Lake Abhé (Table 1). Lake Asal, which is also subjected to strong evaporation, is hypersaline and slightly acidic ( $\mathrm{pH}<7$; Table 1), suggesting that a fresh groundwater supply to this lake is either insignificant or lacking altogether.

Later studies from 1990s inferred that the hot spring fluids jetting in the Asal Rift were a result of seawater-basalt interaction (Sanjuan et al., 1990). Investigations of these fluids in geothermal wells showed that deep in the crust the fluids were hot $\left(260-359^{\circ} \mathrm{C}\right)$, enriched in $\mathrm{Fe}, \mathrm{Zn}, \mathrm{Pb}, \mathrm{Si}$, $\mathrm{Ca}$ and $\mathrm{Li}$, and depleted in $\mathrm{Mg}$ and $\mathrm{SO}_{4}$ (D'Amore et al., 1998). Although they were inferred to 
originate from seawater after interaction with hot basement rocks these hot mineralized fluids were considered disconnected from the Lake Asal water body (D'Amore et al., 1998).

Based on the ideas from previous works (Bäcker et al., 1973; Gasse and Fontes, 1989; Sanjuan et al., 1990; D'Amore et al., 1998) and our data on the chemistry (including isotope composition) of the lake water and hydrothermal fluids jetting around the lake we hypothesize that the Lake Asal is essentially fed by hydrothermal fluids of seafloor-type: seawater modified during its passage through the hot basement rocks.

\subsubsection{Major element evidence for seafloor-type hydrothermal rechu. of of Lake Asal}

Seawater was recognized as a mother fluid of the hydrotherm $1 \mathrm{fl}$ ids jetting into the Asal Rift and their nature appears to be similar to that of the seaflon hyo othermal fluids. However, this begs the question: is Lake Asal fed by hydrothermal flvids 'seafloor type; i.e., born upon hightemperature seawater-rock interaction) or is it filled gra $^{\text {tally }}$ ally beawater percolating through rocks (without any high-temperature seawater-roc s i.teraction)? The major element composition of the Lake Asal water and hydrothermal flv $: \lambda_{s} \iota \cdot n$ provide constraints on these two possibilities.

A fundamental feature of the seawater $\mathrm{c}_{1}$ ' nistry is that the major ions are present in relatively constant ratios. These constant ratios a e not maintained in the seafloor hydrothermal fluids because of the gains and losses of eieluents during sub-seafloor seawater-rock interactions. Chlorine is a conservative eleme thrugh these interactions. According to the previous works (Gasse and Fontes, 1989; Saı,' 'lan et al., 1990) and our physical-chemical parameters measurements (Table 1) the ' $c$ al Rift hydrothermal fluids and Lake Asal water are seawaterbased. The element/ $C_{1} r_{a}: n$ in these fluids will be indicators for gains or losses of elements relative to the starting f'vi (seawater) if the starting fluid has interacted with the rocks. $\mathrm{Na} / \mathrm{Cl}$ of the Lake Asal hydrothermal fluid (0.31) and, particularly, that of the Lake Asal water (0.22-0.24) are lower than that of the seawater $(0.53-0.56)$ (Table 8). This means that the seawater has lost $\mathrm{Na}$ during its reaction with the basement rocks. It is well-known that $\mathrm{Na}$ can be lost from the hydrothermal fluids due to $\mathrm{Na}$ for $\mathrm{Ca}$ replacement reactions in plagioclase, known as albitization (German and Von Damm, 2003). Potassium is obviously also involved in similar type of replacement reaction (e.g., palagonitization) showing depletion in the hydrothermal fluids and even stronger depletion in the Lake Asal water relative to the seawater (Table 8). 
Although Lake Abhé is not seawater-fed we can use the same type of element/Cl ratios for estimation of the enrichment or depletion of the major elements in the studied fluids. Sodium is enriched in the lake water relative to the hydrothermal fluids, whereas $\mathrm{K}$ shows similar ratios in both fluids (Table 8). This may mean that the "excess" of $\mathrm{Na}$ in the lake water is a result of $\mathrm{Na}$ riverine input likely surpassing the $\mathrm{Na}$ deficiency of the hydrothermal fluids. The similar $\mathrm{K} / \mathrm{Cl}$ ratios of the lake water and hydrothermal fluids imply for a balance between the excess and deficiency of $\mathrm{K}$ in these two fluids.

Magnesium and $\mathrm{SO}_{4}{ }^{2-}$ are quantitatively removed from the seawater during its interaction with the basement rocks at the mid-ocean ridges and the end-member sc floor hydrothermal fluids at this setting do not contain them (German and Von Damm, 2013). Although not reaching zero concentrations, these two species are depleted in the Lake Asal hydrothermal fluids (Table 8). The Lake Asal waters are also depleted in $\mathrm{Mg}$ and $\mathrm{SO}_{+}^{2-} 1^{1}$ ative to the seawater, but they are slightly enriched in these species in respect to the hydrot, $\cdots$ nal fluids (Table 8).

Sulfate is enriched in the Lake Abhé waters re' at $v^{\prime}$ to the hydrothermal fluid which suggests excess riverine supply of $\mathrm{SO}_{4}{ }^{2-}$ to the lake o ${ }^{\cdots} \cdots \mathrm{l}_{1}$ - hydrothermal $\mathrm{SO}_{4}{ }^{2-}$ input.

The identical $\mathrm{Br} / \mathrm{Cl}$ ratio in both the $\mathrm{La}^{1}+$ Asal hydrothermal fluids and lake water, and its similarity to that of the seawater ( $\left.\mathrm{Tab}_{\downarrow}, 8\right)$ suggests that $\mathrm{Br}$ behaves conservatively along the entire passage of the seawater througl. $t^{\prime} 1 \mathrm{e}$ iot basement rocks to the Lake Asal.

Calcium enrichment in the Lak 'Asal hydrothermal fluids relative to the seawater (Table 8) is similar to that of the seafloc " $\mathrm{H}_{\text {, }}$ drothermal fluids. Following the analogy with the seafloor hydrothermal circulation (Fe, ${ }_{1} n a$ and Von Damm, 2003) we may infer that although part of the seawater Ca might hav $\mathrm{L}$ ar. immobilized as $\mathrm{CaSO}_{4}$ (anhydrite) in the crust, the dissolution of Ca-plagioclases in the $\Delta_{\text {sal }}$ Rift basement rocks by hydrothermal fluids has provided a net surplus of $\mathrm{Ca}$ in the vent fluids. However, the $\mathrm{Ca} / \mathrm{Cl}$ ratio in the lake water decreases more than 10 times relative to that of the hydrothermal fluids (Table 8). If the hydrothermal fluids are the major source of water to Lake Asal then the drop in the Ca concentration in the lake water (Tables 5, 8) suggests a removal process of $\mathrm{Ca}$ from the water. Even more dramatic depletion in Ca of the Lake Abhé waters relative to the Lake Abhé hydrothermal fluids (Tables 5,8) testifies to a more efficient mechanism of Ca removal from the lake water.

\subsubsection{REE evidence for seawater-based fluid recharge of the Lake Asal}


The PAAS-normalized REE distribution patterns of the Lake Asal water (Fig. 6 C) give additional evidence that the lake water precursor was a seawater-based fluid. These distribution patterns show negative Ce anomaly (Fig. $6 \mathrm{C}$ ) similar to the well-documented negative Ce anomaly of the seawater that is recognized as its common feature (Elderfield and Greaves, 1982; Alibo and Nozaki, 1999; Deng et al., 2017). The Lake Asal water Ce anomaly $(\mathrm{Ce} / \mathrm{Ce} *=0.39$, average of 9 samples, Table 5) is smaller than that of the seawater $(\mathrm{Ce} / \mathrm{Ce} *=0.29$, average of 18 samples along the water column of the Pacific; Deng et al., 2017). A reasonable explanation for this decrease is that the lake water is a fluid evolved from seawater (with pronounced negative Ce anomaly) towards seafloor end-member hydrothermal fluid with ru Ce anomaly (Michard et al., 1983; Klinkhammer et al., 1994).

The PAAS-normalized REE distribution pattern of the ake Abhé water (Fig. $6 \mathrm{C}$ ) shows features discussed in a previous study (Dekov et al., 2011) The pronounced positive Ce anomaly and heavy REE enrichment in the lake water was accoun -2 for by stablilization of carbonato- Ce and HREE aqueous complexes at high alkalinity, warreas the weak positive Eu anomaly could likely be a result of hydrothermal fluid disch - o o lose to the sampling site (Dekov et al., 2014).

\subsubsection{Chemistry of the end-member hya, thermal fluid}

We used the hydrothermal fluid for n vite 3 (sample 3-nov; Table 1) as a fluid close to the hypothetical end-member hydro ernal fluid for Lake Asal because it has ${ }^{87} \mathrm{Sr} /{ }^{86} \mathrm{Sr}$ ratio (0.704396, Table 7) close to that of the local basalt (0.704027, Table 6), and also has very low $\mathrm{SO}_{4} / \mathrm{Cl}$ and $\mathrm{Mg} / \mathrm{Cl}$ ratios ( $\mathrm{Tab}_{\mathbf{i}} \sim \mathrm{s}_{\text {) }}$.

By analogy with the sc fl sor venting fluids (German and Von Damm, 2003), the Lake Asal hydrothermal fluid (e.s sample 3-nov) can be considered as a mixture of the end-member hydrothermal fluid and Lake Asal water. The theoretical end-member hydrothermal fluid should have $\left[\mathrm{SO}_{4}{ }^{2-}\right]=0 \mathrm{~g} / \mathrm{L}$ and chloride concentration $\left(\left[\mathrm{Cl}^{-}\right]\right)$equal to that of seawater if no subsurface boiling and phase separation occurred. However, the venting fluid at the Lake Asal bottom (e.g., 3-nov at Site 3) cannot be described by mixing of such a theoretical end-member hydrothermal fluid with Lake Asal water (Fig. 8). It lies on the mixing line between the Lake Asal water and a fluid with seawater chlorinity $\left(\left[\mathrm{Cl}^{-}\right]=19.6 \mathrm{~g} / \mathrm{L}\right.$; Table 5) and $\left[\mathrm{SO}_{4}{ }^{2-}\right]=0.215 \mathrm{~g} / \mathrm{L}$ (Fig. 8). We will consider this fluid as actual end-member hydrothermal fluid (Fig. 8), which has not completely lost its original seawater sulfate during seawater/rock interaction. Mixing calculations 
show that the fluid venting at the Lake Asal bottom (3-nov) is a mixture of $97 \%$ actual endmember hydrothermal fluid and 3\% lake water (Fig. 8).

The calculated chemistry of the actual end-member hydrothermal fluid of the Lake Asal (Table 9) implies that the end-member hydrothermal fluid of an "embryonic" ocean seems to be poorer in metals than the seafloor hydrothermal fluids of an open and evolved ocean.

\subsection{Isotope composition of an oceanic "embryo" in arid climate: heavy $O, C$ and $C a$, and light $\mathrm{Zn}$}

Our results suggest that the hydrothermal fluids in the Asal Rif that feed Lake Asal are of seafloor type. Hence, these hydrothermal fluids should have stal le isotope signatures similar to those of the seafloor hydrothermal fluids. $\delta^{18} \mathrm{O}$ of the ${ }^{\mathrm{r}}{ }^{-} \mathrm{k}_{\iota}$ Asal hydrothermal fluids $(2.79 \%$; Table 7) is heavier than that of the seafloor hydroth *...al fluids, which have $\delta^{18} \mathrm{O}$ varying between 0 and 2\%o (Shanks, 2001). This heavi $\mathrm{r} J^{18} \mathrm{O}$ value may be attributed to a greater exchange of $\mathrm{O}$ with the crust during hydrot $\left.{ }^{-} \sim \mathrm{r}_{\imath}\right\urcorner 1$ circulation $\left(\delta^{18} \mathrm{O}_{\text {Asal Rift rocks }}=+4.6-+12.2 \%\right.$; Fouillac et al., 1989) probably due to lon 's reaction path and low water/rock ratio. Another possible explanation of this isotope sifference is a subsurface mixing of the upwelling hydrothermal fluids with presumably $\delta^{\top} \uparrow=0-2 \%$ with downwelling lake water with $\delta^{18} \mathrm{O}>$ $4 \%$ (Table 7). If the Lake Asal wa er o.iginates from seawater $\left(\delta^{18} \mathrm{O}=0.85 \%\right.$; Table 7$)$ modified towards heavier oxygen isotc ne values $\left(\delta^{18} \mathrm{O}\right.$ up to $2.79 \%$; Table 7$)$ through seawater/rock interaction, then a further piaf zrential removal of the lighter oxygen isotope $\left({ }^{16} \mathrm{O}\right)$ during evaporation has likely a $^{-a r}$ the additional shift to heavier $\delta^{18} \mathrm{O}$ values (e.g., Rohling, 2013) in the lake water $\left(\delta^{18} \mathrm{O}>4 \%\right.$, Table 7$)$.

The hydrothermal fluids fill the Lake Asal with light $\mathrm{C}$ isotope water $\left(\delta^{13} \mathrm{C}=-2.73 \%\right.$ ) isotopically similar to the local seawater $\left(\delta^{13} \mathrm{C}=-2.89 \%\right.$ ) (Table 7). Further, the strong evaporation likely has led to enrichment of the lake water in ${ }^{13} \mathrm{C}$ (e.g., Horton et al., 2016) and the lake has progressively evolved towards a heavy $\mathrm{C}$ isotope water body $\left(\delta^{13} \mathrm{C}>6 \%\right.$; Table 7 , Fig. 7). This inferred evolution to a heavy $\mathrm{C}$ and $\mathrm{O}$ isotope lake is recorded in the associated authigenic mineral precipitates, carbonate spires, showing gradually increasing $\delta^{13} \mathrm{C}$ and $\delta^{18} \mathrm{O}$ through time (Table 6). The $\delta^{13} \mathrm{C}$ decrease in the surface water layer (Fig. 7) seems to be a result 
of the Suess effect (Keeling, 1979): addition of isotopically lighter anthropogenic $\mathrm{CO}_{2}$ from the atmosphere.

Close similarity of the Ca isotope composition of the Lake Asal hydrothermal fluids (Table 7) to that of the seafloor end-member hydrothermal fluids (Amini et al., 2008; Scheuermann et al., 2018) is an additional argument that the Lake Asal hydrothermal fluids are of seafloor-type. Explanation of how the heavy seawater $\left(\delta^{44} \mathrm{Ca}=1.92 \%\right.$; Fantle and Tipper, 2014) evolves towards a light seafloor-type hydrothermal fluid $\left[\delta^{44} \mathrm{Ca}_{\text {end-member hydrothermal fluid }}=0.88 \%\right.$; Amini et al. (2008), Scheuermann et al. (2018)] with a Ca isotope composition close to that of the midocean ridge basalt $(0.88 \%$ ) can be found elsewhere (Amini et cu. 2008; Scheuermann et al., 2018). In the case of an oceanic "embryo" (e.g., Lake Asa ) es tirely fed by seafloor-type hydrothermal fluids the interesting question is: how has th - oc anic "embryo" got $\mathrm{Ca}$ isotope

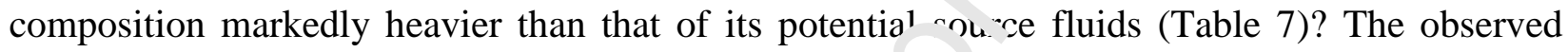

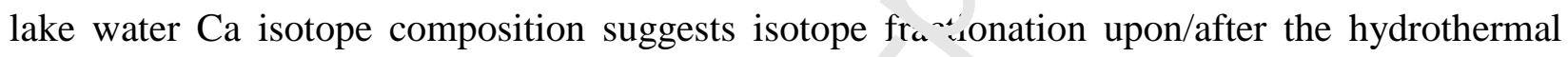
fluid discharge. $\delta^{44} \mathrm{Ca}$ vertical profile across the li Ke rater body (Fig. 7) shows that the heaviest $\mathrm{Ca}$ isotope composition forms close to the 1-1.a $\mathrm{i}$ ttom. The essential chemical reaction in which $\mathrm{Ca}$ is involved during the hydrothermal $\mathrm{d}$ d discharge in the lake is the Ca-carbonate spire deposition. This takes place at the lake $\iota$ רttom. Hence, the Ca-carbonate spire formation appears to be responsible for the $\mathrm{Ca}$ isotop a fr ationation. Laboratory experiments showed that the inorganic precipitation of calcite : $\mathrm{om}$ solution led to $\mathrm{Ca}$ isotope fractionation where the calcite had lighter $\mathrm{Ca}$ isotope compos: tio: than the solution (Tang et al., 2012; AlKhatib and Eisenhauer, 2017a,b). Based on these strairs we can infer that the hydrothermal carbonates building spires at the lake bottom prefere ${ }^{~} 1 c^{11} \mathrm{y}$ retain the light $\mathrm{Ca}$ isotope $\left({ }^{40} \mathrm{Ca}\right)$ of the hydrothermally derived $\mathrm{Ca}$ $\left(\delta^{44} \mathrm{Ca}=0.92 \%\right.$ ) thus, ${ }^{1}{ }^{2}$ ving a fluid with heavy $\mathrm{Ca}$ isotope composition which fills the lake $\left(\delta^{44} \mathrm{Ca}>1.20 \%\right.$ ). Calcium isotope composition of the Lake Asal Ca-carbonate spires that shows an increase in $\delta^{44} \mathrm{Ca}$ through the time of spire formation (from $0.22 \%$ to $1.06 \%$; Table 6 ) accounts for this isotope fractionation. The oldest central part of the spire has $\mathrm{Ca}$ isotope composition $(0.22 \%)$ much lower than that of the venting hydrothermal fluid $(\sim 0.90 \%)$. The further increase of $\delta^{44} \mathrm{Ca}$ (to $1.06 \%$; Table 6 ) of the spire layers can be explained with mixing of the hydrothermal fluid with more heavy lake water $\left(\delta^{44} \mathrm{Ca}>1.20 \%\right.$; Table 7).

The heavy $\mathrm{Ca}$ isotope composition of the Lake Abhé $\left(\delta^{44} \mathrm{Ca}=2.84 \%\right.$; Table 7) cannot be explained by simple mixing of the two major sources of water to it: riverine $\left(\delta^{44} \mathrm{Ca}_{\text {rivers }}=0.2-\right.$ 
1.7\%o; Fantle and Tipper, 2014) and hydrothermal (0.74-0.93\%; Table 7). The heavy Ca isotope composition of the lake water can reasonably be explained with preferential sequestration of the light $\mathrm{Ca}$ isotope $\left({ }^{40} \mathrm{Ca}\right)$ from the fluids by the precipitating $\mathrm{Ca}$-carbonates and residual enrichment of the lake water in the heavy Ca isotope $\left({ }^{44} \mathrm{Ca}\right)$.

If Lake Asal is fed by seawater-derived hydrothermal fluids, the lake water should have an isotopic composition close to that of modern seafloor hydrothermal fluids if no isotope fractionation occurs within the lake reservoir. The Lake Asal water has mostly negative $\mathrm{Zn}$ isotope composition $\left(\delta^{66} \mathrm{Zn}=-0.15-+0.02 \%\right.$; Table 7$)$, which although matching the lighter end of the $\mathrm{Zn}$ isotope compositional range of the seafloor hydrothc. nal fluids $\left(\delta^{66} \mathrm{Zn}=-0.12\right.$ $+1.21 \%$; John et al., 2008) is still lighter than the average seaf or hydrothermal fluid $\left(\delta^{66} \mathrm{Zn}=\right.$ $+0.12 \%$; Little et al., 2014). Even if we assume that the sє iwa er, which fills the lake has not been modified to hydrothermal fluid during its passage thro. gh the Asal Rift rocks the positive $\mathrm{Zn}$ isotope composition of seawater $\left(\delta^{66} \mathrm{Zn}=+0.34 \%\right.$; ${ }^{2}$. 1 et al., 2005) cannot account for the negative $\delta^{66} \mathrm{Zn}$ of the Lake Asal water. It seems like:y that the seafloor-type hydrothermal fluids

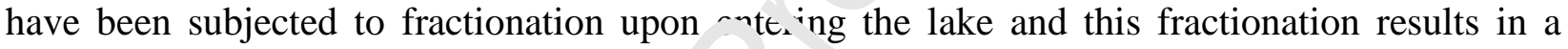
water body with negative $\delta^{66} \mathrm{Zn}$.

When the hydrothermal fluids eme $e_{2}$ e from the lake bottom they discharge part of their chemical load in the form of carbol ate spires. The carbonate spires with their positive $\delta^{66} \mathrm{Zn}$ ( 0.07 - 0.23\%; Table 6) are poten. al candidates for fractionating the $\mathrm{Zn}$ isotopes.

Previous studies found t' at $7 \mathrm{n}$ adsorbed on calcite (Dong and Wasylenki, 2016) or coprecipitated with calcite $\left(N_{1} \cdot v\right.$ vomatis et al., 2019) was isotopically heavier than that in the coexisting fluid. In a hige ic ni, strength fluid the average $\Delta^{66} \mathrm{Zn}_{\text {adsorbed-fluid }}$ was $0.73 \%$ (Dong and Wasylenki, 2016). Dor ¿ and Wasylenki (2016) consider this as an equilibrium fractionation between dissolved $\mathrm{Zn}$ and calcite-sorbed $\mathrm{Zn}$ that is sensitive to aqueous $\mathrm{Zn}$ speciation. Their mass balance calculations showed that a pool of isotopically light $\mathrm{Zn}$ is complexed with $\mathrm{Cl}^{-}$in high ionic strength solutions, leading to a heavier pool of $\mathrm{Zn}$ adsorbed on the calcite surface.

The Lake Asal system includes (1) seafloor-type hydrothermal fluids, (2) highly saline (high ionic strength) lake water that is a result of hydrothermal fluid accumulation and its evolution as a lake body, and (3) carbonate spires that grow at the lake bottom as a result of the interaction between the first two components. The source fluid (component 1) has presumably positive $\mathrm{Zn}$ isotope composition $\left[\delta^{66} \mathrm{Zn}_{\text {average }}=+0.12 \%\right.$ ( Little et al., 2014); ranging from -0.12 to $+1.21 \%$ o 
(John et al., 2008)], whereas the lake water (component 2$)$ has negative $\left(\delta^{66} \mathrm{Zn}_{\text {average }}=-0.06 \%\right.$; Table 7) and the carbonate spires (component 3 ) have positive $\left(\delta^{66} \mathrm{Zn}_{\text {average }}=0.17 \%\right.$; Table 6$) \mathrm{Zn}$ isotope compositions. A reasonable explanation of the observed isotopically light lake water and isotopically heavy carbonate spires is $\mathrm{Zn}$ isotope fractionation during carbonate spire formation due to $\mathrm{Zn}$ adsorption on carbonates (calcite and aragonite) (e.g., Dong and Wasylenki, 2016).

Overall, unlike an open and evolved modern ocean with $\delta^{13} \mathrm{C}$ ranging from -6.56 to $+3.10 \%$ (Cheng et al., 2019), $\delta^{18} \mathrm{O}$ ranging from -1.5 to $+1.8 \%$ (Carpenter and Lohmann, 1995) and positive $\mathrm{Zn}$ isotope composition $\left(\delta^{66} \mathrm{Zn}=+0.34 \%\right.$; John et al., 2005) the ocean at "embryonic" stage has heavy both $\mathrm{C}$ and $\mathrm{O}$ isotope composition $\left(\delta^{13} \mathrm{C}>6 \%\right.$, $\delta^{18} \mathrm{O}>4 \%$; Table 7$)$ and negative $\mathrm{Zn}$ isotope composition $\left(\delta^{66} \mathrm{Zn}_{\text {average }}=-0.06 \%\right.$ ). Calci. $\eta \mathrm{i}$, otope compositions of both types of ocean are similarly heavy: $\delta^{44} \mathrm{Ca}_{\text {open evolved ocean }}=1.9 \%$ (Fantle and Tipper, 2014), $\delta^{44}$ Ca"embryonic" ocean $=1.22-1.64 \%$ (Table 7$)$.

\subsection{Hydrothermal discharge from the lake bottom a id aeolian input to the lake surface}

Although we have not observed and $\operatorname{san}_{\Lambda_{1}}$ led venting fluids from the Lake Asal bottom our data suggests that this lake is fed by hy' 'rothermal fluids of seafloor type. The vertical profile across the Lake Asal water body at Sit: ( 1 (Fig. 1 B; Table 1) shows a number of evidence for hydrothermal discharge from the 'ake bottom close to this site. The lower end of $\mathrm{C} 1$ profile (samples C1-1 (23 m) and C1-¿ (1_ m)) has (1) low pH, high alkalinity and elevated T [high $\mathrm{CO}_{2}$ content of the venting flu; ${ }_{i}$ wir result in a decrease of $\mathrm{pH}$ and increase of alkalinity (Zeebe and Wolf-Gladrow, 2001)]; ? : iuW concentrations of $\mathrm{SO}_{4}{ }^{2-}$ (the end-member hydrothermal fluid has zero sulfate)); (3) high unncentrations of $\mathrm{Zn}, \mathrm{Cu}, \mathrm{Mn}, \mathrm{Sn}, \mathrm{Ag}, \mathrm{Pb}, \mathrm{Mo}$ and $\mathrm{Si}$ (the hydrothermal fluids are rich in these elements); and (4) the lightest both $\delta^{18} \mathrm{O}$ (towards the hydrothermal fluid value), and $\delta^{34} \mathrm{~S}_{\mathrm{SO} 4}$ (towards the hydrothermal fluid value), and $\delta^{66} \mathrm{Zn}$ (Zn isotope fractionation during carbonate spire formation; see 6.2) (Fig. 7). The low concentrations of $\mathrm{V}$ and $\mathrm{Ni}$ at the lake bottom (samples $\mathrm{C} 1-1$ ( $23 \mathrm{~m} ; \mathrm{V}=2.16 \mathrm{ppb}, \mathrm{Ni}=1.85 \mathrm{ppb})$ and $\mathrm{C} 1-2(15 \mathrm{~m} ; \mathrm{V}=2.12 \mathrm{ppb}$, $\mathrm{Ni}=1.70 \mathrm{ppb})$ ), even below their content in the hydrothermal fluid $(\mathrm{V}=74.1 \mathrm{ppb}, \mathrm{Ni}=2.09 \mathrm{ppb}$; Fig. 7), can be explained by adsorption on and co-precipitation with hydrothermally precipitated carbonates (e.g., Olsson et al., 2014) at the lake bottom. All this data suggests a hydrothermal discharge from the lake bottom close to Site $\mathrm{C} 1$. 
In addition to the near-bottom hydrothermal signature, the vertical distributions of the concentrations of some elements across the Lake Asal water body show another essential feature: surface maxima (Fig. 7). The surface maxima of $\mathrm{Cl}^{-}$and $\mathrm{SO}_{4}{ }^{2-}$ concentrations, which correlates positively with that of the temperature, can be explained as a result of the solar heating and salinity increase due to evaporation. An alternative explanation of the $\mathrm{Cl}^{-}$and $\mathrm{SO}_{4}{ }^{2-}$ content surface maxima as well as those of the concentrations of $\mathrm{Fe}, \mathrm{Mn}, \mathrm{Cu}, \mathrm{V}, \mathrm{Ni}, \mathrm{U}$ and $\mathrm{Co}$ (Fig. 7) is that they are possibly a result of aeolian (windblown) input to the lake surface. Whereas Fe, Mn, $\mathrm{Cu}, \mathrm{V}, \mathrm{Ni}, \mathrm{U}$ and $\mathrm{Co}$ can be supplied within the windblown dust (e.g., Mendez et al., 2010; Sholkovitz et al., 2010) from the nearby deserts, $\mathrm{Cl}^{-}$and $\mathrm{SO}_{4}{ }^{2-}$ can. kely be delivered to the lake within the windblown marine aerosols (e.g., Fitzgerald, 1991) f. om he nearby ( 200 km; Fig. 1 A) ocean. The sharp decrease in the concentrations of $\mathrm{Fe}, \mathrm{Mr}, \mathrm{Cu}, \mathrm{V}, \mathrm{Ni}, \mathrm{U}$ and $\mathrm{Co}$ in the subsurface water layer (sample C1-4 (5 m)) (Fig. 7) se:ms to be a result of their oxidation or scavenging. Zinc isotope composition of the surface wate-'ayer (Fig. 7) also suggests for aeolian dust input. Unlike the waters below the surface (t ef prr than $5 \mathrm{~m}$ ) that have negative $\delta^{66} \mathrm{Zn}$ (see 6.2) the surface water layer has positive $\delta^{66} 7$ ( ( 9 able 7, Fig. 7). This trend of heavier $\delta^{66} \mathrm{Zn}$ from the bottom towards the lake surface can be - plained with aeolian supply of dust having isotope composition of the instantly soluble $\mathrm{Zn}$ of $0.25 \%$ very close to $\delta^{66} \mathrm{Zn}_{\text {Earth crust }}=0.18 \%$ o (Little et al., 2014).

This suggests that there are twe genutically different sources of elements to the Lake Asal that are vertically separated: hydro' he. nal (lower, or bottom) and aeolian (upper, or surficial).

\subsection{Oceanic "embryos" $\iota$. ad climate: acidic and metal rich}

We infer that Lake Asal is fed by seafloor-type hydrothermal fluids and that the hydrothermal fluid venting at Site 3 (3-nov) can be regarded as a fluid type that fills the lake. If no precipitation or accumulation of the elements supplied by the hydrothermal fluid occur in the lake, then the lake water should have chemical composition similar to that of the hydrothermal fluid. However, we observe enrichment of some elements and depletion of others in the lake water relative to the hydrothermal fluid (Table 5; Fig. 7). In respect to the elemental concentrations in the lake water relative to their concentrations in the hydrothermal fluid the studied elements can be divided in two groups: (1) elements that are enriched in the lake water relative to the hydrothermal fluid 
( $\mathrm{Zn}, \mathrm{Cu}, \mathrm{Mn}, \mathrm{Sn}, \mathrm{Pb}, \mathrm{U}$, and $\mathrm{Co}$ ), and (2) elements that are depleted in the lake water relative to the hydrothermal fluid (Fe, Ag, V, Mo, and $\mathrm{Si}$ ) (Table 5; Fig. 7). The first group of elements has obviously been accumulated in the lake water, whereas the elements from the second group have been removed from the source fluid.

Previous studies showed that under hydrothermal conditions the chloride complexes are the predominant Zn (Mei et al., 2015; Zhong et al., 2015), Cu (Liu and McPhail, 2005; Zhong et al., 2015), Pb (Zhong et al., 2015), Mn (Tian et al., 2014), Sn (Schmidt, 2018) and Co (Liu et al., 2011) species. We can hypothesize that the chloride complexes of $\mathrm{Zn}, \mathrm{Cu}, \mathrm{Pb}, \mathrm{Mn}, \mathrm{Sn}$ and $\mathrm{Co}$ injected with the hydrothermal fluids into the hypersaline Lake A..$^{1}$ water have been stabilized and accumulated with time. The most remarkable accuml'atio $\mathrm{n}$ is that of $\mathrm{Zn}$ showing concentration in the lake water two orders of magnitude high $r$ th $n$ that in the hydrothermal fluid (Fig. 7). Uranium accumulation in the Lake Asal water :s a'so notable (Fig. 7). In the starting fluid, seawater, $\mathrm{U}$ has an average concentration of $3.3 \mathrm{pw}$ : (Ku et al., 1977). However, during the hydrothermal circulation through the oceanic c cus,$U$ behaves coherently with $\mathrm{Mg}$ and is quantitatively removed ( 98\%) from seawa+ ( 1 ichard and Albarède, 1985; Chen et al., 1986). Consequently, the seafloor end-member hy." sthermal fluids are depleted in U. Indeed, the Lake Asal hydrothermal fluid is two orders oi magnitude depleted in $\mathrm{U}$ relative to the seawater (Table 5; Fig. 7). However, in the Lake As.1 w. wer U obviously accumulates: its concentration is two orders of magnitude higher than ti: at in the hydrothermal fluid (Table 5; Fig. 7). The minimum in the $\mathrm{U}$ concentration at $5 \mathrm{~m} \mathrm{wa}$ 'er depth (Fig. 7) may be due to scavenging on the particulate $\mathrm{Fe}$ oxyhydroxides (e.g., German c $^{+}$.., 1991) inferred to happen at that depth (see 6.3).

The low $\mathrm{pH}$ of the ivant'ermal fluids filling the Lake Asal accounts for the mild acidity of the lake water (Table 1; Fig. 7). On the other hand, simple evaporation of seawater can result in a decrease in the $\mathrm{pH}$ from $~ 8.2$ to 7.0 (McCaffrey et al., 1987; Isaji et al., 2017). However, evaporation alone cannot explain $\mathrm{pH}$ value of down to 6.54 like that in the Lake Asal (Table 1). Therefore, the only reasonable explanation for the mildly acidic water of the Lake Asal is its hydrothermal origin. Indeed, the $\mathrm{pH}$ of the Lake Asal hydrothermal fluids (Table 1) is within the $\mathrm{pH}$ range of the modern seafloor hydrothermal fluids (German and Von Damm, 2003). The $\mathrm{pH}$ variations in these fluids depend generally on the temperature, water/rock ratio and precipitation of some minerals (e.g., anhydrite) (Pierre et al., 2018). Thus, the $\mathrm{pH}$ variation in the hydrothermal fluids measured during different sampling campaigns (Table 1) may be ascribed to variations of 
temperature, water/rock ratio and mineral precipitation in the discharge zone of the hydrothermal system. These variations likely account for the different $\mathrm{pH}$ of the Lake Asal hydrothermal fluid (Site 3) and Lake Asal bottom water (samples C1-1, C1-2) inferred to be recharged by hydrothermal fluids.

Our calculations show a striking accumulation of some metals (notably $\mathrm{Li}, \mathrm{Mn}$ and $\mathrm{Zn}$ ) in the Lake Asal water (Table 10) and suggest that an "embryonic" ocean located in an arid zone is metal rich and mildly acidic.

\subsection{Formation of carbonate spires in the Lake Asal: $(\mathrm{Mg} / \mathrm{Ca})_{\text {mol }}{ }^{\mathrm{CG}}{ }^{4}{ }^{4}{ }^{\text {rol on }}$ spire mineralogy}

The vertical, spire-like form of the carbonate deposits ai the Lake Asal shore suggests they formed underwater (e.g., Dekov et al., 2014). This seem 1 asonable in view of the substantial fluctuations of the Lake Asal water body in response to li climatic changes during the Holocene (Gasse and Fontes, 1989). The carbonate spi es likely formed during the interaction of hydrothermal fluids with lake water, similar ' $\mathrm{n}$ 'e carbonate spires of the Lake Abhé (Dekov et al., 2014) and tufa towers of the alkaline $1_{a}{ }^{\prime}$ 's (Bischoff et al., 1993; Rosen et al., 2004). U-Th age dating of the spires suggests that the, had grown from the central zone outwards (Table 6).

Mineralogical zonation of the spir зs, $1, \mathrm{w}-\mathrm{Mg}$ calcite + aragonite in the central (oldest) zone and aragonite + low-Mg calcite it. the Juter (younger) layers (Table 2; Fig. 4), gives some clues for the conditions of spire formainn. According to the previous studies, the inorganic carbonate precipitation in seawater is nr.n.rily controlled by seawater $\mathrm{Mg} / \mathrm{Ca}$ molar ratio (Sandberg, 1975; Wilkinson, 1979; Hat tit, 1 J96; Morse et al., 1997). At $(\mathrm{Mg} / \mathrm{Ca})_{\mathrm{mol}} \leq 1$ low-Mg calcite precipitates, whereas at $1 \leqslant(\mathrm{Mg} / \mathrm{Ca})_{\mathrm{mol}} \leq 2$ high-Mg calcite precipitates. At $(\mathrm{Mg} / \mathrm{Ca})_{\mathrm{mol}}$ from $\sim 2$ to the present-day seawater value of 5.2 aragonite precipitates along with high-Mg calcite. At ratios substantially above 5 only aragonite precipitates.

Thus, from the Lake Asal hydrothermal fluid with $(\mathrm{Mg} / \mathrm{Ca})_{\mathrm{mol}}=0.24$ (Table 5) only low- $\mathrm{Mg}$ calcite can precipitate. Lake Asal water has $(\mathrm{Mg} / \mathrm{Ca})_{\mathrm{mol}}=6.70$, which is well above that of the local seawater $\left[(\mathrm{Mg} / \mathrm{Ca})_{\mathrm{mol}}=5.40\right]$ (Table 5) and high enough for aragonite precipitation only. Mixing of these two fluids will result in mixed carbonates (low-Mg calcite, high-Mg calcite and aragonite) depending on the proportions of the fluids. Thus, the central (oldest) zone of the spires composed dominantly of low-Mg calcite had likely precipitated from a fluid mixture dominated 
by a low $(\mathrm{Mg} / \mathrm{Ca})_{\text {mol }}$ hydrothermal fluid $\left[(\mathrm{Mg} / \mathrm{Ca})_{\text {mol }}<2\right.$; Fig. $\left.9 \mathrm{~A}\right]$. In contrast, the younger spire layers (LAs-2 and -1) composed dominantly of aragonite had precipitated from a fluid mixture dominated by a high $(\mathrm{Mg} / \mathrm{Ca})_{\text {mol }}$ lake water $\left[(\mathrm{Mg} / \mathrm{Ca})_{\text {mol }}>2\right.$; Fig. $\left.9 \mathrm{~B}, \mathrm{C}\right]$. However, the Lake Asal water has high $\mathrm{Mg} / \mathrm{Ca}$ molar ratio now and the studied spires formed $~ 15600$ years ago (Table 6 ). Did the lake water have the same $\mathrm{Mg} / \mathrm{Ca}$ molar ratio at the time of spire formation? Following our hypothesis that the Lake Asal water has originated from a seafloor-type hydrothermal fluid it seems logical to assume that at the beginning of the lake filling the primordial lake water had $(\mathrm{Mg} / \mathrm{Ca})_{\mathrm{mol}}$ close to that of the hydrothermal fluid $(<2)$. The high $(\mathrm{Mg} / \mathrm{Ca})_{\mathrm{mol}}$ of the recent lake water is obviously a result of long evolution of the low pr $\ldots$ ary $(\mathrm{Mg} / \mathrm{Ca})_{\text {mol }}$. Since the hydrothermal fluid is, in general, depleted in $\mathrm{Mg}$ (Table 5) it is . ot $\mathrm{r}$ :asonable to assume that the $(\mathrm{Mg} / \mathrm{Ca})_{\text {mol }}$ increase of the lake water may have been due tc hyc rothermal fluid portions rich in

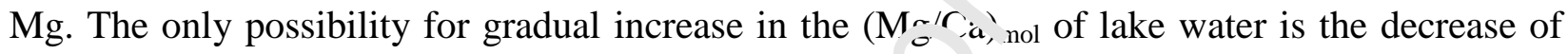
the $\mathrm{Ca}$ concentrations in it. The most plausible mechan al of Ca removal from the Lake Asal water seems to be Ca-carbonate deposition. In of e vords, the carbonate spire precipitation in the lake is a mineralogy self-control mechar $\sim \sim m$. nrecipitation of Ca-carbonate removes $\mathrm{Ca}$ from the lake water, increases $(\mathrm{Mg} / \mathrm{Ca})_{\mathrm{mol}}$ of the ${ }^{\prime} \cdot \mathrm{e}$ water and drives spire mineralogy from calcite to aragonite.

Overall, at the early stages of the $\mathrm{La}^{\prime}$.e a sal development the lake water $(\mathrm{Mg} / \mathrm{Ca})_{\mathrm{mol}}$ was close to that of the hydrothermal fluid ( 2 ) and the precipitated spires were composed of calcite (low$\mathrm{Mg}$ calcite) (Fig. 9 A). With t me the net removal of $\mathrm{Ca}$ to calcite (low-Mg calcite) spires at the lake bottom drove the $\left(\mathrm{Mg} / \mathrm{C}_{\mathfrak{a}},{ }_{1}\right.$ of lake water to high values $(>2)$ and precipitation of aragonite dominated layers in $\mathrm{t}_{1} \boldsymbol{s}_{\mathbf{1}} \mathbf{i r}_{-} \mathrm{s}$ (Fig. 9 B,C). Mixed carbonate composition of the spire layers (low-Mg calcite domin ${ }^{\star r} \mathrm{~d}$ with aragonite, or aragonite dominated with low-Mg calcite) is a result of mixing of different proportions of the interplaying fluids: low $(\mathrm{Mg} / \mathrm{Ca})_{\text {mol }}$ hydrothermal fluid and high $(\mathrm{Mg} / \mathrm{Ca})_{\text {mol }}$ lake water.

Lake Abhé spire had also grown from the central zone outwards (Table 6) and is composed of alternating layers of low-Mg calcite and high-Mg calcite (Table 2). We do not have data on the $(\mathrm{Mg} / \mathrm{Ca})_{\mathrm{mol}}$ of Lake Abhé hydrothermal fluids, but may presume that they have $(\mathrm{Mg} / \mathrm{Ca})_{\mathrm{mol}}<1$ as a result of $\mathrm{Mg}$ sequestration during water-rock interaction. The Lake Abhé water has $(\mathrm{Mg} / \mathrm{Ca})_{\mathrm{mol}}$ $=1.18$ (Table 5). Thus, the alternation of low-Mg and high-Mg calcite layers within the spire is 
reasonably explained with fluctuation in the proportions of the mixing fluids: hydrothermal fluid and lake water.

\subsection{Hydrothermal fluid/lake water contribution to the spire composition: Sr isotope constraints}

We infer that the hydrothermal fluids venting at the Lake Asal shores are seawater, which has been modified during its interaction with the Asal Rift rocks: i.e., seafloor-type hydrothermal fluid. The hydrothermal fluid at Site 3 (sample 3-nov) was estimated to have chemical composition close to that of the actual end-member fluid (see 6.1.3). Its $\mathrm{Sr}$ isotope composition is close to that of the local basalt and away from the $\mathrm{Sr}$ isotope con pos tion of the seawater (Fig. 10 A; Tables 6, 7). Lake Asal water, which is accumulation of i vdr thermal fluid modified through evaporation and mineral precipitation, has $\mathrm{Sr}$ isotope crmw sition between those of the source fluid (hydrothermal fluid) and seawater (Fig. $10 \mathrm{~A}$; Tabi $-6,7)$. Hydrothermal carbonate spires at the Lake Asal bottom are a result of the interar tir $n$ between the hydrothermal fluids and lake water. Therefore, simple mixing calculation insed on the Sr concentrations and Sr isotope composition for these two fluids can give . 2 proportions of the interacting fluids. We can see that at the beginning of the LAs spire for mation $59 \%$ of its $\mathrm{Sr}$ is hydrothermally derived (Fig. 10 A). Meaning that the hydrothermal $f_{i} u$ accounts for $59 \%$ of the spire composition. The hydrothermal contribution to the are composition increases to $68 \%$ in the younger spire layers (LAs-2 and -1; Fig. 10 A).

Similarly, mixing calculatı ns for the Lake Abhé hydrothermal fluid and lake water show that high proportion of hyc'ro' mal fluid (82-73\%) accounts for the composition of the low-Mg calcite layers (LAb-1, - - -4), whereas high proportion of lake water (88-96.5\%) is responsible for the composition of the high-Mg calcite layers (LAb-3, -5, -6, -7, -8) (Fig. $10 \mathrm{~B}$ ). In addition to the evidence that the Lake Abhé hydrothermal fluid is a result of interaction of water (groundwater?) with the local basalts the Sr isotope data suggest that the Lake Abhé water largely originates from the Awash River (Fig. 10 B).

Elemental concentrations and stable isotope ratios correlate with the proportions hydrothermal fluid/lake water that participated in the spire formation (Fig. 11). The correlation of Sr, Ba, REE and Th concentrations in the Lake Abhé spire with the lake water proportion (Fig. 11 A2, A4) suggests that the lake water is the major source of these elements in the spire. The evaporation 
and related heavy $\mathrm{C}$ and $\mathrm{O}$ isotope composition of the lake water accounts for similar positive correlation of $\delta^{13} \mathrm{C}$ and $\delta^{18} \mathrm{O}$ of the spire with the lake water proportion (Fig. 11 A5). The correlation of the $\mathrm{Cu}$ concentration and magnitude of $\mathrm{Eu}$ anomaly $\left(\mathrm{Eu} / \mathrm{Eu}^{*}\right)$ with the hydrothermal fluid proportion (Fig. 11 A3) suggests that the hydrothermal fluid is the major source of $\mathrm{Cu}$ and $\mathrm{Eu}$ in the Lake Abhé spire.

Major hydrothermal supply of $\mathrm{Cu}, \mathrm{Zn}, \mathrm{Ni}$ and $\mathrm{Co}$ to the Lake Asal spire explains their increased concentrations in the spire layers with high hydrothermal proportion (Fig. 11 B2, B3). The decreasing $\mathrm{Eu}$ anomaly $\left(\mathrm{Eu} / \mathrm{Eu}^{*}\right)$ with increasing hydrothermal proportion in the spire layers (Fig. 11 B4) may be explained with progressive maturation of ive hydrothermal system and exhausted in Eu source rocks. The increase in $\delta^{13} \mathrm{C}$ and $\delta^{18} \mathrm{O}$ witl the decrease in lake water proportion in the spire layers (Fig. 11 B5) may be due to $\mathrm{p}$. rtic pation of smaller proportion of more evolved due to evaporation lake water: i.e., isotor: $: h_{1}$, heavier. The positive $\delta^{66} \mathrm{Zn}$ in the Lake Asal spires (Fig. 11 B6) was explained with $\mathrm{Zn}$, , tope fractionation due to preferential ${ }^{66} \mathrm{Zn}$ adsorption on carbonates (see 6.2). The ir cr-a ed hydrothermal proportion in the spire layers is seemingly responsible for the heavi ${ }_{-\alpha} 5^{4} 7 \mathrm{n}$ (Fig. 11 B6).

\subsection{Oceanic "embryos" with light $\mathrm{Fe}$ ?}

The correlation between the $\delta^{6}{ }^{6} \mathrm{Fe}$ values of the carbonate spire samples and hydrothermal fluid proportion participating in heir precipitation (Fig. 11 A6, B6) implies for Fe isotope fractionation during spire $f_{n} \cdot n_{1}$. Due to analytical challenges we could not obtain $\mathrm{Fe}$ isotope data for the investiga ' adids: hydrothermal and lake water (Table 7). However, in our interpretations we can w $\mathrm{Fe}$ isotope data from the previous works. If the fluids that fill Lake Asal are seafloor-type hydrothermal fluids (see 6.1), they should have an Fe isotope composition similar to that of modern seafloor hydrothermal fluids, which ranges from -0.12 to $-0.45 \%$ (Beard et al., 2003; Severmann et al., 2004). Lake Asal carbonate spire samples have heavier $\delta^{56} \mathrm{Fe}$ values $(-0.14-+0.07 \%$; Table 6$)$ relative to the seafloor vent fluids $\left(\delta^{56} \mathrm{Fe}=-0.45-\right.$ $0.12 \%$, $\delta^{56} \mathrm{Fe}_{\text {average }}=-0.29 \%$; Beard et al., 2003; Severmann et al., 2004), consistent with fractionation during oxidation of $\mathrm{Fe}^{2+}{ }_{\text {aq }}$ to $\mathrm{Fe}^{3+}$ aq (e.g., Severmann et al., 2004). Indeed, the $\mathrm{Fe}^{2+}{ }_{\text {aq }}$ dissolved in the low-oxygen Lake Asal hydrothermal fluid $\left(\left[\mathrm{O}_{2}\right]=0-0.08 \mathrm{mg} / \mathrm{L}\right.$, Site 3; Table 1) will be readily oxidized in the Lake Asal water with oxygen concentration of $1.90-8.80 \mathrm{mg} / \mathrm{L}$ 
(Table 1). The oxidation of $\mathrm{Fe}^{2+}{ }_{\text {aq }}$ to $\mathrm{Fe}^{3+}{ }_{\text {aq }}$ and precipitation of $\mathrm{Fe}^{3+}$-minerals in the spires will produce the observed positive $\mathrm{Fe}$ isotope fractionation and $\delta^{56} \mathrm{Fe}$ increase relative to the parent hydrothermal fluid (Table 6). We may speculate that the carbonate spire formation at the Lake Asal bottom will result in deep lake water with Fe isotope composition lighter than that of the seafloor hydrothermal fluids: $\delta^{56} \mathrm{Fe}<-0.12 \%$. On the other hand, the Lake Asal surface receives Fe from the wind-blown dust (see 6.3). The average Fe isotope composition of the aerosols, supposed to be the source of dissolved Fe in the Lake Asal surface water, is $+0.10 \%$ (Beard et al., 2003). Hence, the Lake Asal water will have $\delta^{56} \mathrm{Fe}$ ranging from the negative values of the seafloor hydrothermal fluids $(<-0.12 \%)$ to the positive values of the aeolian dust $(+0.10 \%)$. It appears that unlike an evolved open ocean with positive $\delta^{56} \mathrm{Fe}(+024-+0.71 \%$; Boyle et al., 2012) an "embryonic" ocean is at a state of "anemia" with i ght (rather negative) $\delta^{56} \mathrm{Fe}$ (Tanaka and Hirata, 2018).

\section{Summary: Scenarios of formation of the Lak : fs al and Lake Abhé}

Lake Asal, located at the point of inu "stion between an oceanic spreading ridge and a continental rift system, is considered $h$ be an ocean at "embryonic" stage because the crust beneath it is of oceanic type and its $w a t / r$ ody is seawater-based. Scarce fresh water supply (rare rainfalls, questionable groundwa ${ }^{2}$ r liux and no riverine input) seems to be a subordinate component in the lake water huiget. Our data suggest that the lake is fed almost entirely by seafloor-type hydrothermal $\mathrm{fl}_{\mathrm{L}}: \mathrm{d}$. The dense network of faults and cracks related to extension in the Asal-Ghoubbet Riı n, vi es pathways for the seawater to percolate down to the Asal tectonic depression (Fig. 12). F"ning its passage to the Asal Rift the seawater is heated by the heat released from the magma reservoir located below the rift, reacts with the host rocks (mostly basalts) and evolves towards a seafloor-type hydrothermal fluid. These fluids fill the Asal depression and make the lake water body. Thus, the seawater/rock interaction seems to be the first control on the chemistry of an oceanic "embryo". Strong evaporation superimposed on the seafloor-type hydrothermal fluid pool is another control on its chemistry. The hyper salinity (high chloride content) caused by the evaporation leads to stabilization of many hydrothermally supplied metals as chloride complexes and their accumulation in the lake water. As a result, this type of "embryonic" ocean appears to be metal rich and mildly acidic. In addition, the 
evaporation leads to a heavy $\mathrm{C}$ and $\mathrm{O}$ isotope composition of the water body. The interaction between the hydrothermal fluids and lake water results in deposition of carbonate spires at the lake bottom and this process appears to be a third control on the chemistry of an oceanic "embryo". Ca-carbonate precipitation changes the $(\mathrm{Mg} / \mathrm{Ca})_{\text {mol }}$ of lake water and this results in changes in the carbonate mineralogy of the spires: from low-Mg calcite to aragonite. Adsorption on, co-precipitation with, and oxidation in Ca-carbonates results in $\mathrm{Zn}, \mathrm{Ca}$ and $\mathrm{Fe}$ isotope fractionation and changes in the isotope composition of the lake water. In addition to the hydrothermal supply of chemical elements from the lake bottom the lake water body receives elements through the wind-blown dust. Thus, an oceanic "embryu" located in an arid zone has two genetically different sources of elements that are vertically sep rated: hydrothermal (lower, or bottom) and aeolian (upper, or surficial).

Lake Abhé forms in a continental rift: Gob Aad Basin (ẗ.g. 13). However, unlike Lake Asal, Lake Abhé is generally fed by fresh water from t.- Awash River. Subjected to strong evaporation, Lake Abhé evolves towards saline a ld rasic lake. In addition to the fresh riverine water the lake is fed by hot hydrothermal ${ }^{n}{ }^{1} \mathrm{ll}$ 's. The Lake Abhé hydrothermal fluids, unlike those of Lake Asal, originate from fresh gi "ndwater after its heating by local magmatic bodies and interaction with the host rocks. Carb nate chimneys form at the points of mixing between the hydrothermal fluids and lake water.

\section{Acknowledgements}

This research was supno ${ }^{\circ}$ d by a Tokyo University of Marine Science and Technology internal grant, which i gte iully acknowledged. We are extremely grateful to the Djiboutian Government and Army $f, r$ their efforts to facilitate our sampling campaigns. The numerous suggestions and constructive comments by an anonymous reviewer improved the paper significantly and are highly appreciated.

\section{Declaration of interests}

The authors declare that they have no known competing financial interests or personal relationships that could have appeared to influence the work reported in this paper.

\section{References}


Alibo, D.S., Nozaki, Y., 1999. Rare earth elements in seawater: particle association, shale-normalization, and Ce oxidation. Geochim. Cosmochim. Acta 63, 363-372.

AlKhatib, M., Eisenhauer, A., 2017a. Calcium and strontium isotope fractionation in aqueous solutions as a function of temperature and reaction rate; I. Calcite. Geochim. Cosmochim. Acta 209, 296-319.

AlKhatib, M., Eisenhauer, A., 2017b. Calcium and strontium isotope fractionation during precipitation from aqueous solutions as a function of temperature and reaction rate; II. Aragonite. Geochim. Cosmochim. Acta 209, 320-342.

Amini, M., Eisenhauer, A., Böhm, F., Fietzke, J., Bach, W., Garbe-Schönberg, D., Rosner, M., Bock, B., Lackschewitz, K.S., Hauff, F., 2008. Calcium isotope $\left(\delta^{44 / 40} \mathrm{Ca}\right)$ fractionation along hydrothermal pathways, Logatchev field (Mid-Atlantic Ridge, $14^{\circ} 45^{\prime} \mathrm{N}$ ). Geochim. Cosmochim. Acta 72, 4107-4122.

Aminot, A., Kérouel, R., 2007. Dosage automatique des nutriments dans les eaux marines: méthodes en flux continu. Ed. Ifremer, Méthodes d'analyse en milieu marin. $188 \mathrm{p}$.

Araoka, D., Yoshimura, T., 2019. Rapid purification of alkali and alkaline-earth elements for isotope analysis $\left(\delta^{7} \mathrm{Li}\right.$, $\delta^{26} \mathrm{Mg}{ }^{87} \mathrm{Sr} /{ }^{86} \mathrm{Sr}$, and $\delta^{88} \mathrm{Sr}$ ) of rock samples using borate fusion followed by ion chromatography with a fraction collector system. Anal. Sci. 35, 751-757.

Audin, L., Quidelleur, X., Coulié, E., Courtillot, V., Gilder, S., Manighetti, I. Filı‘ P.-Y., Tapponnier, P., Kidane, T., 2004. Palaeomagnetism and $\mathrm{K}-\mathrm{Ar}$ and ${ }^{40} \mathrm{Ar} /{ }^{39} \mathrm{Ar}$ ages in the Ali : abie area (Republic of Djibouti and Ethiopia): constraints on the mechanism of Aden ridge propagation in ${ }^{\prime} \mathrm{s}$. Ilureastern Afar during the last $10 \mathrm{Myr}$. Geophys. J. Int. 158, 327-345.

Bäcker, H., Clin, M., Lange, K., 1973. Tectonics in the Gulf of Tadjura. Mar. Geol. 15, 309-327.

Barberi, F., Tazieff, H., Varet, J., 1972. Volcanism in the Afar di pres ion: Its tectonic and magmatic significance. Tectonophysics 15, 19-29.

Barberi, F., Civetta, L., Varet, J., 1980. Sr isotopic compositio. of A.ar volcanics and its implication for mantle evolution. Earth Planet. Sci. Lett. 50, 247-259.

Barrat, J.-A., Jahn, B.M., Fourcade, S., Joron, J.L., 199? Ma $a_{\xi .+1}$ genesis in an ongoing rifting zone: The Tadjoura Gulf (Afar area). Geochim. Cosmochim. Acta 57, 2< 11-८?02.

Barrat, J.-A., Boulègue, J., Tiercelin, J.J., Les $v d$, M., 2000. Strontium isotopes and rare-earth element geochemistry of hydrothermal carbonate reposits 1. om Lake Tanganyika, East Africa. Geochim. Cosmochim. Acta 64, 287-298.

Bastow, I.D., Keir, D., 2011. The protracted de lopment of the continent-ocean transition in Afar. Nat. Geosci. 4, 248-250.

Bayon, G., Henderson, G.M., Etoublea J., Taprais, J.-C., Ruffine, L., Marsset, T., Dennielou, B., Cauquil, E., Voisset, M., Sultan, N., 2015. U-T ${ }^{\mathfrak{l}}$ isou xe constraints on gas hydrate and pockmark dynamics at the Niger delta margin. Mar. Geol. 370, 87-98.

Beard, B.L., Johnson, C.M., Von '`amn , K.L., Poulson, R.L., 2003. Iron isotope constraints on Fe cycling and mass balance in oxygenated Eart'، oc ans. Geology 31, 629-632.

Benson, L., 1994. Carbona.' d nos' ion, Pyramid Lake Subbasin, Nevada: 1. Sequence of formation and elevational distribution of carbonate dt, osits (Tufas). Palaeogeogr. Palaeocl. Palaeoecol. 109, 55-87.

Bischoff, J.L., Stine, S., Ros . vauer, R.J., Fitzpatrick, J.A., Stafford, Jr. T.W., 1993. Ikaite precipitation by mixing of shoreline springs and lake water, Mono Lake, California, USA. Geochim. Cosmochim. Acta 57, 3855-3865.

Boschetti, T., Awaleh, M.O., Barbieri, M., 2018. Waters from the Djiboutian Afar: A review of strontium isotopic composition and a comparison with Ethiopian waters and Red Sea brines. Water 10, 1700.

Boyle, E.A., John, S., Abouchami, W., Adkins, J.F., Echegoyen-Sanz, Y., Ellwood, M., Flegal, A.R., Fornace, K., Gallon, C., Galer, S., Gault-Ringold, M., Lacan, F., Radic, A., Rehkamper, M., Rouxel, O., Sohrin, Y., Stirling, C., Thompson, C., Vance, D., Xue, Z., Zhao, Y., 2012. GEOTRACES IC1 (BATS) contamination-prone trace element isotopes $\mathrm{Cd}, \mathrm{Fe}, \mathrm{Pb}, \mathrm{Zn}, \mathrm{Cu}$, and Mo intercalibration. Limnol. Oceanogr.: Methods 10, 653-665.

Böhm, F., Gussone, N., Eisenhauer, A., Dullo, W.-C., Reynaud, S., Paytan, A., 2006. Calcium isotope fractionation in modern scleractinian corals. Geochim. Cosmochim. Acta 70, 4452-4462.

Branchu, P., Bergonzini, L., Delvaux, D., De Batist, M., Golubev, V., Benedetti, M., Klerkx, J., 2005. Tectonic, climatic and hydrothermal control on sedimentation and water chemistry of northern Lake Malawi (Nyasa), Tanzania. J. Afr. Earth Sci. 43, 433-446. 
Bretzler, A., Osenbrück, K., Gloaguen, R., Ruprecht, J.S., Kebede, S., Stadler, S., 2011. Groundwater origin and flow dynamics in active rift systems - A multi-isotope approach in the Main Ethiopian Rift. J. Hydrol. 402, 274289.

Carpenter, S.J., Lohmann, K.C., 1995. $\delta^{18} \mathrm{O}$ and $\delta^{13} \mathrm{C}$ values of modern brachiopod shells. Geochim. Cosmochim. Acta 59, 3749-3764.

Chen, J.H., Wasserburg, G.J., Von Damm, K.L., Edmond, J.M., 1986. The U-Th-Pb systematics in hot springs on the East Pacific Rise at $21^{\circ} \mathrm{N}$ and in the Guaymas Basin. Geochim. Cosmochim. Acta 50, 2467-2479.

Cheng, H., Edwards, R.L., Shen, C.-C., Polyak, V.J., Asmerom, Y., Woodhead, J., Hellstrom, J., Wang, Y., Kong, X., Spötl, C., Wang, X., Alexander, Jr. E.C., 2013. Improvements in ${ }^{230}$ Th dating, ${ }^{230} \mathrm{Th}$ and ${ }^{234} \mathrm{U}$ half-life values, and U-Th isotopic measurements by multi-collector inductively coupled plasma mass spectrometry. Earth Planet. Sci. Lett. 371-372, 82-91.

Cheng, L., Normandeau, C., Bowden, R., Doucett, R., Gallagher, B., Gillikin, D.P., Kumamoto, Y., McKay, J.L., Middlestead, P., Ninnemann, U., Nothaft, D., Dubinina, E.O., Quay, P., Reverdin, G., Shirai, K., Mørkved, P.T., Theiling, B.P., van Geldern, R., Wallace, D.W.R., 2019. An internation.' intercomparison of stable carbon isotope composition measurements of dissolved inorganic carbon in seawntar. : imnol. Oceanogr.: Methods 17, 200-209.

Cotton, J., Le Dez, A., Bau, M., Caroff, M., Maury, R.C., Dulski, P., F su `au, S., Bohn, M., Brousse, R., 1995. Origin of anomalous rare-earth element and yttrium enrichments in . 'bar rially exposed basalts: evidence from French Polynesia. Chem. Geol. 119, 115-138.

Courtillot, V., Galdéano, A., Le Mouel, J.L., 1980. Propagation of an a creting plate boundary: A discussion of new aeromagnetic data in the Gulf of Tadjurah and Southern Afar. Ea th 'lanet. Sci. Lett. 47, 144-160.

Courtillot, V., Achache, J., Landre, F., Bonhommet, N., Galiheıı, P.Y., Montigny, R., Féraud, G., 1984. Episodic spreading and rift propagation: New paleomagnetic an $g$ o hronologic data from the Afar passive margin. J. Geophys. Res. 89, 3315-3333.

Damak, F., Asano, M., Baba, K., Suda, A., Araokr, D. Wa'i', A., Isoda, H., Nakajima, M., Ksibi, M., Tamura, K., 2019. Interregional traceability of Tunisian olive $r$ s to the provenance soil by multielemental fingerprinting and chemometrics. Food Chem. 283, 656-664.

D'Amore, F., Giusti, D., Abdallah, A., 1998. Gea hemistry of the high-salinity geothermal field of Asal, Republic of Djibouti, Africa. Geothermics 27, 197-21'

Dekov, V.M., Egueh, N.M., Kamenov, C D., B₹yon, G., Lalonde, S.V., Schmidt, M., Liebetrau, V., Munnik, F., Fouquet, Y., Tanimizu, M., Awaleh, Y.O., Juirreh, I., Le Gall, B., 2014. Hydrothermal carbonate chimneys from a continental rift (Afar Rift): Mine: logy, geochemistry and mode of formation. Chem. Geol. 387, 87-100.

Deng, Y., Ren, J., Guo, Q., Cao, J., Wa.'g, H., Liu, C., 2017. Rare earth element geochemistry characteristics of seawater and porewater from a. ap st a in western Pacific. Sci. Rep. 7, 16539.

Dong, S., Wasylenki, L.E., 2 1 (U. Zinc isotope fractionation during adsorption to calcite at high and low ionic strength. Chem. Geol. $4^{17}$, ?7-7 s.

Doubre, C., Manighetti, I., L rbath, C., Dorbath, L., Jacques, E., Delmond, J.C., 2007. Crustal structure and magmato-tectonic proces,$\quad$ in an active rift (Asal-Ghoubbet, Afar, East Africa): 1. Insights from a 5-month seismological experiment. J. Geophys. Res. 112, B05405.

Elderfield, H., Greaves, M.J., 1982. The rare earth elements in seawater. Nature 296, 214-219.

Fantle, M.S., Tipper, E.T., 2014. Calcium isotopes in the global biogeochemical Ca cycle: Implications for development of a Ca isotope proxy. Earth-Sci. Rev. 129, 148-177.

Fitzgerald, J.W., 1991. Marine aerosols: A review. Atmos. Environ. Part A. General Topics 25, 533-545.

Fouillac, A.M., Fouillac, C., Cesbron, F., Pillard, F., Legendre, O., 1989. Water-rock interaction between basalt and high-salinity fluids in the Asal Rift, Republic of Djibouti. Chem. Geol. 76, 271-289.

Friedman, G.M., 1959. Identification of carbonate minerals by staining methods. J. Sediment. Petrol. 29, 87-97.

Gasse, F., Fontes, J.-C., 1989. Palaeoenvironments and palaeohydrology of a tropical closed lake (Lake Asal, Djibouti) since 10,000 yr B.P. Palaeogeogr. Palaeoclimatol. Palaeoecol. 69, 67-102.

German, C.R., Von Damm, K.L., 2003. Hydrothermal processes. In: Turekian, K.K., Holland, H.D. (Eds), Treatise on Geochemistry, Vol. 6 The Oceans and Marine Geochemistry, Elsevier, Oxford, pp. 181-222.

German, C.R., Fleer, A.P., Bacon, M.P., Edmond, J.M., 1991. Hydrothermal scavenging at the Mid-Atlantic Ridge: radionuclide distributions. Earth Planet. Sci. Lett. 105, 170-181. 
Goldsmith, J.R., Graf, D.L., 1958. Relation between lattice constants and composition of the Ca-Mg carbonates. Am. Mineral. 43, 84-101.

Granina, L.Z., Klerkx, J., Callender, E., Leermakers, M., Golobokova, L.P., 2007. Bottom sediments and pore waters near a hydrothermal vent in Lake Baikal (Frolikha Bay). Russ. Geol. Geophys. 48, 237-246.

Hardie, L.A., 1996. Secular variation in seawater chemistry: An explanation for the coupled secular variation in the mineralogies of marine limestones and potash evaporites over the past 600 m.y. Geology 24, 279-283.

Heuser, A., Eisenhauer, A., Gussone, N., Bock, B., Hansen, B.T., Nägler, T.F., 2002. Measurement of calcium isotopes $\left(\delta^{44} \mathrm{Ca}\right)$ using a multicollector TIMS technique. Int. J. Mass Spectrom. 220, 387-399.

Hori, M., Takashima, C., Marsuoka, J., Kano, A., 2009. Carbon and oxygen stable isotopic measurements of carbonate and water samples using mass spectrometer with gas bench. Bulletin of the Graduate School of Social and Cultural Studies, Kyushu University 15, 51-57.

Horton, T.W., Defliese, W.F., Tripati, A.K., Oze, C., 2016. Evaporation induced ${ }^{18} \mathrm{O}$ and ${ }^{13} \mathrm{C}$ enrichment in lake systems: A global perspective on hydrologic balance effects. Quat. Sci. Rev. 131, 365-379.

Isaji, Y., Kawahata, H., Kuroda, J., Yoshimura, T., Ogawa, N.O., Suzuki, A. Shibuya, T., Jiménez-Espejo, F.J., Lugli, S., Manzi, V., Roveri, M., Ohkouchi, N., 2017. Biological and phycinal .'odification of carbonate system parameters along the salinity gradient in shallow hypersaline solar salte ns in Trapani, Italy. Geochim. Cosmochim. Acta 208, 354-367.

John, S.G., Bergquist, B.A., Saito, M.A., Boyle, E.A., 2005. Zinc isotrpe var ttions in phytoplankton and seawater. Geochim. Cosmochim. Acta 69, A546.

John, S.G., Rouxel, O.J., Craddock, P.R., Engwall, A.M., Boy e, L A., 2008. Zinc stable isotopes in seafloor hydrothermal vent fluids and chinmeys. Earth. Planet. Sci. Lett. $2^{60}, 17-28$.

Keeling, C.D., 1979. The Suess effect: ${ }^{13}$ Carbon- ${ }^{14}$ Carbon interrelations. Environ. Int. 2, 229-300.

Klinkhammer, G.P., Elderfield, H., Edmond, J.M., Mitra, A , ' 9. 4. Geochemical implications of rare earth element patterns in hydrothermal fluids from mid-ocean ridges Geuvilm. Cosmochim. Acta 58, 5105-5113.

Ku, T.-L., Knauss, K.G., Mathieu, G.G., 1977. U anı m 1 open ocean: concentration and isotopic composition. Deep-Sea Res. 24, 1005-1017.

Labidi, J., Cartigny, P., Birck, J.L., Assayag, N., Bourı nd, J.J., 2012. Determination of multiple sulfur isotopes in glasses: A reappraisal of the MORB $\delta^{34}$ S. Che. ?. Geol. 334, 189-198.

Little, S.H., Vance, D., Walker-Brown, C., La . ring, W.M., 2014. The oceanic mass balance of copper and zinc isotopes, investigated by analysis of their in suts, and outputs to ferromanganese oxide sediments. Geochim. Cosmochim. Acta 125, 673-693.

Liu, W., McPhail, D.C., 2005. Therm ody mic properties of copper chloride complexes and copper transport in magmatic-hydrothermal solutions. Chr n. Geol. 221, 21-39.

Liu, W., Borg, S.J., Testemalt, D., Etschmann, B., Hazemann, J.-L., Brugger, J., 2011. Speciation and thermodynamic properties s or $~-~ b$ balt chloride complexes in hydrothermal fluids at 35-440 C and 600 bar: An insitu XAS study. Geoch. ?. ('nsr schim. Acta 75, 1227-1248.

Liu, H.-C., You, C.-F., Huan, K.-F., Chung, C.-H., 2012. Precise determination of triple Sr isotopes $\left(\delta^{87} \mathrm{Sr}\right.$ and $\delta^{88} \mathrm{Sr}$ ) using MC-ICP-MS. *alanta 88, 338-344.

Ludwig, K.R., 2011. Using Isoplot/Ex, Version 4.15. A geochronological toolkit for Microsoft Excel: Berkeley Geochronology Ctr. Spec. Pub. 4.

Manighetti, I., Tapponnier, P., Gillot, P.-Y., Jacques, E., Courtillot, V., Armijo, R., Ruegg, J.C., King, G., 1998. Propagation of rifting along the Arabia-Somalia plate boundary: Into Afar. J. Geophys. Res. 103, B3, 4947-4974.

Marechal, C.N., Telouk, P., Albarede, F., 1999. Precise analysis of copper and zinc isotopic compositions by plasmasource mass spectrometry. Chem. Geol. 156, 251-273.

Maruo, M., Doi, T., Obata, H., 2006. Onboard determination of submicromolar nitrate in seawater by anionexchange chromatography with lithium chloride eluent. Anal. Sci. 22, 1175-1178.

Mavromatis, V., González, A.G., Dietzel, M., Schott, J., 2019. Zinc isotope fractionation during the inorganic precipitation of calcite - Towards a new pH proxy. Geochim. Cosmochim. Acta 244, 99-112.

McCaffrey, M.A., Lazar, B., Holland, H.D., 1987. The evaporation path of seawater and the coprecipitation of $\mathrm{Br}^{-}$ and $\mathrm{K}^{+}$with halite. J. Sediment. Petrol. 57, 928-937. 
Mei, Y., Sherman, D.M., Liu, W., Etschmann, B., Testemale, D., Brugger, J., 2015. Zinc complexation in chloriderich hydrothermal fluids $\left(25-600^{\circ} \mathrm{C}\right)$ : A thermodynamic model derived from ab initio molecular dynamics. Geochim. Cosmochim. Acta 150, 265-284.

Mendez, J., Guieu, C., Adkins, J., 2010. Atmospheric input of manganese and iron to the ocean: Seawater dissolution experiments with Saharan and North American dusts. Mar. Chem. 120, 34-43.

Michard, A., Albarède, F., 1985. Hydrothermal uranium uptake at ridge crests. Nature 317, 244-246.

Michard, A., Albaréde, F., Michard, G., Minster, J.F., Charlou, J.-L., 1983. Rare earth elements and uranium in hightemperature solutions from East Pacific Rise hydrothermal vent field $\left(13^{\circ} \mathrm{N}\right)$. Nature 303, 795-797.

Millero, F.J., 2003. Physicochemical controls on seawater. In: Turekian, K.K., Holland, H.D. (Eds), Treatise on Geochemistry, Vol. 6 The Oceans and Marine Geochemistry, Elsevier, Oxford, pp. 1-21.

Minami, T., Konagaya, W., Zheng, L., Takano, S., Sasaki, M., Murata, R., Nakaguchi, Y., Sohrin, Y., 2015. An offline automated preconcentration system with ethylenediaminetriacetate chelating resin for the determination of trace metals in seawater by high-resolution inductively coupled plasma mass spectrometry. Anal. Chim. Acta 854, 183-190.

Morita, S., Takagi, T., Kon, Y., Araoka, D., 2016. The accuracy and determinntion limits of rock chemical analysis by X-ray fluorescence spectrometry at Mineral Resources Research Gr up, Jeological Survey of Japan. GSJ Open-File Report 624, 36 p.

Morse, J.W., Wang, Q., Tsio, M.Y., 1997. Influences of temperature ${ }^{n}{ }^{\prime}$ Ms .Ca ratio on $\mathrm{CaCO}_{3}$ precipitates from seawater. Geology 25, 85-87.

Needham, H.D., Choukroune, P., Cheminee, J.L., Le Pichon, K., Trancheteau, J., Tapponnier, P., 1976. The accreting plate boundary Ardoukoba Rift (northeast Africa) anc thr oceanic Rift Valley. Earth Planet. Sci. Lett. 28, 439-453.

Olsson, J., Stipp, S.L.S., Makovicky, E., Gislason, S.R., $2{ }^{<}<$Metal scavenging by calcium carbonate at the Eyjafjallajökull volcano: A carbon capture and storag^ anaısue. Chem. Geol. 384, 135-148.

Paris, G., Sessions, A.L., Subhas, A.V., Adkins, J 4 ., 01 . MC-ICP-MS measurement of $\delta^{34}$ S and $\Delta^{33}$ S in small amounts of dissolved sulfate. Chem. Geol. $345, \ldots$, $\lrcorner 1$.

Parkhurst, D.L., Appelo, C.A.J., 2013. Descrintion of : sput and examples for PHREEQC version 3 - A computer program for speciation, batch-reaction, one-ı mensional transport, and inverse geochemical calculations. U.S. Geological Survey Techniques and Methe ds - A43, 497 p.

Pflumio, C., Boulègue, J., Tiercelin, J.-J., 1994 Fydrothermal activity in the Northern Tanganyika Rift, East Africa. Chem. Geol. 116, 85-109.

Pierre, S., Gysi, A.P., Monecke, T., 2 118. ᄀluid chemistry of mid-ocean ridge hydrothermall vents: A comparison between numerical modeling ana renı reochemical data. Geofluids 2018, Article ID 1389379.

Ragueneau, O., Savoye, N., Del ‘'mo. Y., Cotton, J., Tardiveau, B., Leynaert, A., 2005. A new method for the measurement of biogenic sica $n$ suspended matter of coastal waters: using Si:Al ratios to correct for the mineral interference. Cont. She ${ }^{-} R_{t} \cdot 2^{5}, 697-710$.

Renaut, R.W., Owen, R.B., Joı es, B., Tiercelin, J.-J., Tarits, C., Ego, J.K., Konhauser, K.O., 2013. Impact of lakelevel changes on the forr.. on of thermogene travertine in continental rifts: Evidence from Lake Bogoria, Kenya Rift Valley. Sedimentology 60, 428-468.

Rohling, E.J., 2013. Oxygen isotope composition of seawater. In: Elias, S.A. (Ed.), The Encyclopedia of Quaternary Science, Vol. 2, Elsevier, Amsterdam, pp. 915-922.

Rosen, M.R., Arehart, G.B., Lico, M.S., 2004. Exceptionally fast growth rate of <100-yr-old tufa, Big Soda Lake, Nevada: Implications for using tufa as a paleoclimate proxy. Geology 32, 409-412.

Sandberg, P.A., 1975. New interpretations of Great Salt Lake ooids and of ancient non-skeletal carbonate mineralogy. Sedimentology 22, 497-537.

Sanjuan, B., Michard, G., Michard, A., 1990. Origine des substances dissoutes dans les eaux des sources thermales et des forages de la région Asal-Ghoubbet (République de Djibouti). J. Volcanol. Geotherm. Res. 43, 333-352.

Scheuermann, P.P., Syverson, D.D., Higgins, J.A., Pester, N.J., Seyfried, Jr. W.E., 2018. Calcium isotope systematics at hydrothermal conditions: Mid-ocean ridge vent fluids and experiments in the CaSO4-NaCl-H2O system. Geochim. Cosmochim. Acta 226, 18-35.

Schmidt, C., 2018. Formation of hydrothermal tin deposits: Raman spectroscopic evidence for an important role of aqueous Sn(IV) species. Geochim. Cosmochim. Acta 220, 499-511. 
Schmidt, G.A., Bigg, G.R., Rohling, E.J., 1999. Global Seawater Oxygen-18 Database - v1.22". http://data.giss.nasa.gov/o18data/.

Severmann, S., Johnson, C.M., Beard, B.L., German, C.R., Edmonds, H.N., Chiba, H., Green, D.R.H., 2004. The effect of plume processes on the $\mathrm{Fe}$ isotope composition of hydrothermally derived $\mathrm{Fe}$ in the deep ocean as inferred from the Rainbow vent site, Mid-Atlantic Ridge, 36²1'N. Earth Planet. Sci. Lett. 225, 63-76.

Shanks, III W.C., 2001. Stable isotopes in seafloor hydrothermal systems: Vent fluids, hydrothermal deposits, hydrothermal alteration, and microbial processes. Rev. Mineral. Geochem. 43, 469-525.

Sholkovitz, E.R., Sedwick, P.N., Church, T.M., 2010. On the fractional solubility of copper in marine aerosols: Toxicity of aeolian copper revisited. Geophys. Res. Lett. 37, L20601.

Sohrin, Y., Urushihara, S., Nakatsuka, S., Kono, T., Higo, E., Minami, T., Norisuye, K., Umetani, S., 2008. Multielemental determination of GEOTRACES key trace metals in seawater by ICPMS after preconcentration using an ethylenediaminetriacetic acid chelating resin. Anal. Chem. 80, 6267-6273.

Stein, R.S., Briole, P., Ruegg, J.-C., Tapponnier, P., Gasse, F., 1991. Contemporary, Holocene, and Quaternary deformation of the Asal Rift, Djibouti: Implications for the mechanics of slc * spreading ridges. J. Geophys. Res. 96, B13, 21789-21806.

Stieltjes, L., 1975. Research for a geothermal field in a zone of oceanic spre ding example of the Asal Rift (French territory of the Afar and the Issdas, Afar depression, East Africa). Pro . ${ }^{\text {na }}$ U.N. Symp. On the Development and Use of Geothermal Resources. San Francisco, U.S.A. 1, 613-623.

Tanaka, Y., Hirata, T., 2018. Stable isotope composition of metal t. ${ }^{`}$ ments in biological samples as tracers for element metabolism. Anal. Sci. 34, 645-655.

Tang, J., Niedermayr, A., Köhler, S.J., Böhm, F., Kısakürek, B., L ${ }^{*}{ }^{\circ}$.hauer, A., Dietzel, M., 2012. $\mathrm{Sr}^{2+} / \mathrm{Ca}^{2+}$ and ${ }^{44} \mathrm{Ca} /{ }^{40} \mathrm{Ca}$ fractionation during inorganic calcite formation: III. I.npact of salinity/ionic strength. Geochim. Cosmochim. Acta 77, 432-443.

Taylor, S.R., McLennan, S.M., 1985. The Continental Ci ust. .w Composition and Evolution. Blackwell Scientific, Oxford, $312 \mathrm{p}$.

Tian, Y., Etschmann, B., Mei, Y., Grundler, P.V., e emale, D., Hazemann, J.-L., Elliott, P., Ngothai, Y., Brugger, J., 2014. Speciation and thermodynamic properties if manganese(II) chloride complexes in hydrothermal fluids: In situ XAS study. Geochim. Cosmochim. Ac : 129, 77-95.

Tiercelin, J.-J., Pflumio, C., Castrec, M., Bor ‘ẹs • •. J., Gente, P., Rolet, J., Coussement, C., Stetter, K.O., Huber, R., Buku, S., Mifundu, W., 1993. Hydrothorm 'l ents in Lake Tanganyika, East African Rift system. Geology 21, 499-502.

Vellutini, P., 1990. The Manda-Ina' ir k'ft, Republic of Djibouti: a comparison with the Asal Rift and its

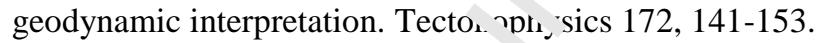

Vigny, C., de Chabalier, J.-B., K 'egg. J.-C., Huchon, P., Feigl, K.L., Cattin, R., Asfaw, L., Kanbari, K., 2007. Twenty-five years of geo eth measurements along the Tadjoura-Asal rift system, Djibouti, East Africa. J. Geophys. Res. 112, BG $11 \mathrm{C}$

Weis, D., Kieffer, B., Maers halk, C., Pretorius, W., Barling, J., 2005. High-precision Pb-Sr-Nd-Hf isotopic characterization of USGS ${ }^{-1}$ VVO-1 and BHVO-2 reference materials. Geochem. Geophys. Geosyst. 6, Q02002.

Wilkinson, B.H., 1979. Biomineralization, paleoceanography, and the evolution of calcareous marine organisms. Geology 7, 524-527.

Wright, T.J., Sigmundsson, F., Pagli, C., Belachew, M., Hamling, I.J., Brandsdóttir, B., Keir, D., Pedersen, R., Ayele, A., Ebinger, C., Einarsson, P., Lewi, E., Calais, E., 2012. Geophysical constraints on the dynamics of spreading centres from rifting episodes on land. Nat. Geosci. 5, 242-250.

Yoshimura, T., Araoka, D., Tamenori, Y., Kuroda, J., Kawahata, H., Ohkouchi, N., 2018. Lithium, magnesium and sulfur purification from seawater using an ion chromatograph with a fraction collector system for stable isotope measurements. J. Chromatogr. A 1531, 157-162.

Zan, L., Gianelli, G., Passerini, P., Troisi, C., Haga, A.O., 1990. Geothermal exploration in the Republic of Djibouti: Thermal and geological data of the Hanlé and Asal areas. Geothermics 19, 561-582.

Zeebe, R.E., Wolf-Gladrow, D., 2001. $\mathrm{CO}_{2}$ in Seawater: Equilibrium, Kinetics, Isotopes. Elsevier, Amsterdam, 360 p.

Zhang, J., Quay, P.D., Wilbur, D.O., 1995. Carbon isotope fractionation during gas-water exchange and dissolution of $\mathrm{CO}_{2}$. Geochim. Cosmochim. Acta 59, 107-114. 
Zhong, R., Brugger, J., Chen, Y., Li, W., 2015. Contrasting regimes of $\mathrm{Cu}, \mathrm{Zn}$ and $\mathrm{Pb}$ transport in ore-forming hydrothermal fluids. Chem. Geol. 395, 154-164.

Fig. 1. (A) Digital elevation model of the eastern part of the Afar Rift showing the extensional fault network in the Lake Abhé - Lake Asal area: a range of horsts and grabens. Vertical color scale $=$ altitude in $\mathrm{m}$; red lines $=$ faults; rectangle encloses the Asal-Ghoubbet Rift (enlarged in B); for Legend see B. (B) Tectonics and volcanism of the Asal-Ghoubbet Rift with the sampling sites. F = Fieale volcano, SB = Shark Bay volcano.

Fig. 2. Inactive carbonate spires at the shores of the Lake Asa' $(\mathrm{A}, \div-1.20 \mathrm{~m}$ tall), and Lake Abhé (B) $(\sim 12 \mathrm{~m}$ tall).

Fig. 3. Cross-sections of the studied spires with sampie lo ations: (A) spire LAs from the Lake Asal (samples LAs-3, -2, -1); (B) spire LAb fron .'e ' 'ake Abhé (samples LAb-1, -2, .. -8). For location of the spires see Figure 1 A,B.

Fig. 4. Photomicrographs (thin sectim $\iota^{f}$ sample LAs stained with Feigl's solution, optical polarizing microscope, transmitte - $\mathrm{li}_{i}{ }^{\text {tr }}$ ) of: (A) concentrically zoned Mg-calcite (Mg-cc) crystals ( $\| \mathrm{N}$; LAs-3); (B) same is a. (A) at $\times \mathrm{N}$; (C) aragonite needle-like crystals (ar; black) over Mg-calcite (Mg-cc; transpareni, and overgrown by Mg-calcite (transparent) (\|N; transition between LAs-3 and LAs- L); (D) same as at (C) at $\times \mathrm{N}$; (E) botryoids of needle-like aragonite (ar; black) overgrown by $\mathrm{Mg}$ - alcite (Mg-cc; transparent) (\|N; LAs-2); (F) same as at (E) at $\times \mathrm{N} ;(\mathrm{G})$ needle-like aragonite crystals (ar; black) overgrown by Mg-calcite $(\mathrm{Mg}-\mathrm{cc}$; transparent) $(\| \mathrm{N}$; LAs-1); (H) same as at $(\mathrm{G})$ at $\times \mathrm{N}$. For the positions of samples LAs-3, $-2,-1$ see Figure $3 \mathrm{~B}$.

Fig. 5. Photomicrographs (thin section of sample LAb, optical polarizing microscope, transmitted light) of: (A) cross-section of botryoidal surface of the layer LAb-3 showing radial Mg-calcite (Mg-cc) crystals ( $\| \mathrm{N}$; LAb-3); (B) same as at (A) at $\times \mathrm{N}$; (C) skeletal Mg-calcite (Mg-cc) crystals $(\| N$; LAb-1); (D) same as at (C) at $\times N$. For the positions of samples LAb-3, -1 see Figure 3 A. 
Fig. 6. Post-Archean Australian Shale-normalized (Taylor and McLennan, 1985) REE distribution patterns of: (A) Lake Asal spire (LAs); (B) Lake Abhé spire (LAb) (open symbols = low-Mg calcite samples, closed symbols = high-Mg calcite samples; for sample mineralogy see Table 2); and (C) Lake Asal and Lake Abhé waters. For sample locations and IDs see Figure 3 and Table 1.

Fig. 7. Vertical distributions of $\mathrm{pH}, \mathrm{T}$, alkalinity, concentrations of major dissolved species and trace elements, and isotope ratios across the Lake Asal water body: C1 profile. For data values, see Tables 1, 5 and 7. HF = data values for the hydrothermal fluid ic ference sample 3-nov, Site 3, Lake Asal. Surface, intermediate, and bottom water layers are oive $\mathrm{n}$ in blue colors: from light blue (surface water) to deep blue (bottom water).

Fig. 8. Sulfate-chloride concentration diagram and mixi water and end-member hydrothermal fluid. Seaw atf $\mathrm{S}\left(\left[\mathrm{Cl}^{-}\right]=19.6 \mathrm{~g} / \mathrm{L},\left[\mathrm{SO}_{4}{ }^{2-}\right]=2.77 \mathrm{~g} / \mathrm{L}\right.$; (Table 5)) is the primary fluid from which the th- re. ical end-member hydrothermal fluid originates after seawater/rock interaction, and loss or $\mathrm{C}_{4}{ }^{2-}$ and retention of $\mathrm{Cl}^{-}\left(\left[\mathrm{Cl}^{-}\right]=19.6 \mathrm{~g} / \mathrm{L},\left[\mathrm{SO}_{4}{ }^{2-}\right]=0\right.$

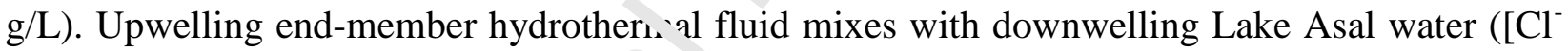
]$_{\text {average }}=277 \mathrm{~g} / \mathrm{L},\left[\mathrm{SO}_{4}{ }^{2-}\right]_{\text {average }}=3.47 \mathrm{~g}, \mathrm{~L}$, ( : able 5)) and vents at the lake bottom. Venting fluid (Site 3 hydrothermal fluid with $\left[\mathrm{C}^{-}{ }^{-}\right]={ }^{\prime} \mathrm{L} .2 \mathrm{~g} / \mathrm{L}$ and $\left[\mathrm{SO}_{4}{ }^{2-}\right]=0.31 \mathrm{~g} / \mathrm{L}$ (Table 5)) does not lie on the mixing line between the theo:-tı al end-member hydrothermal fluid and Lake Asal water. For more explanations see the toxı.

Fig. 9. Scenario of for n'tion of the carbonate spires from the Lake Asal: (A) Hydrothermal fluids migrate along faults/fractures in the basalt basement and discharge at the lake bottom. Mixed hydrothermal fluid-lake water has $(\mathrm{Mg} / \mathrm{Ca})_{\mathrm{mol}}<2$, low-Mg calcite + aragonite precipitate and build the core of the spire. (B) and (C) $(\mathrm{Mg} / \mathrm{Ca})_{\text {mol }}$ of the mixed hydrothermal fluid-lake water increases $\left[(\mathrm{Mg} / \mathrm{Ca})_{\mathrm{mol}}>2\right]$ and aragonite + low-Mg calcite precipitate. The spire grows outwards.

Fig. 10. Sr isotope composition for: (A) Asal Rift basalt, Lake Asal hydrothermal fluid, Lake Asal spire, Lake Asal water (average) and seawater from the Ghoubbet-al-Kharab (Tables 6, 7); 
(B) Lake Abhé basalt (Dama Ale volcano; Barberi et al., 1980), Lake Abhé hydrothermal fluid (average; Table 7), Lake Abhé spire (Table 6), Lake Abhé water (Table 7) and Awash River (Bretzler et al., 2011). Mixing between hydrothermal fluid and lake water can explain the isotope composition of the spires, for more discussion see the text. Percents above bars show the relative amount of hydrothermal fluid $\mathrm{Sr}$ in the carbonate.

Fig. 11. Distribution of hydrothermal fluid contribution (1), elemental concentrations and ratios $(2,3,4)$, and isotope composition $(5,6)$ across the spires of the Lake Abhé (A) and Lake Asal (B).

Fig. 12. Scenario of the Lake Asal formation: (A) Initial st. ge if discrete hydrothermal ponds. The Asal Rift as a north-west propagation of the Asal Shc יbbet Rift (Fig. 1 A) forms due to crustal extension and rifting. Asal Rift depression is $\mathrm{L}^{1} \mathrm{uW}$ the sea level in the Ghoubbet-alKharab and the seawater is pumped by the hydrat is pressure into the depression through cracks and faults. Seawater is heated by the high r-at . Iux released from the magma chamber beneath the rift, interacts with the rocks (dominantly ' asalts) and discharges in the Asal Rift depression as hot springs of seafloor-type. Hydrothe nal fluids fill separated ponds. (B) Stage of full lake. Hydrothermal fluids fill the Asal depı $2 s, 11,1$ and form the Lake Asal. Carbonate spires precipitate at the points of hydrothermal disc. $\arg$ c on the lake bottom. Lake reaches maximum volume. (C) Recent stage of shrinking lake the high evaporation results in a decrease in the lake volume, saturation of the lake water in : rumber of salts and salt precipitation. The lake evolves towards a hypersaline, mildly acl 'ic . nr' enriched in some metals oceanic "embryo".

Fig. 13. Scenario of the Lake Abhé formation. Lake Abhé is fed by the Awash River in the Gob Aad Basin nearby the Dama Ale active volcano (Fig. 1 A). Groundwater beneath the lake is heated by the local magma chamber, interacts with the rocks and discharges as hot hydrothermal fluid in the lake. Carbonate spires form at the points of hydrothermal discharge on the lake bottom. High evaporation causes saturation of the lake water in some salts. The lake evolves towards a saline and basic water body.

Table 1 Investigated fluid samples from the Afar Rift.

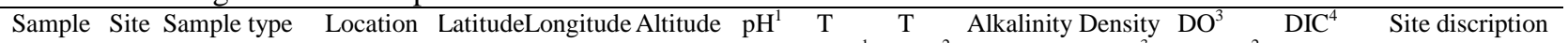

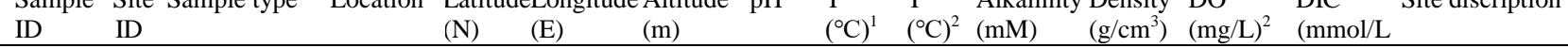




\begin{tabular}{|c|c|c|c|c|c|c|c|c|c|c|c|c|}
\hline & & & & & & & & & & & ) & \\
\hline 1 & $\begin{array}{l}\text { Site seawater } \\
1\end{array}$ & 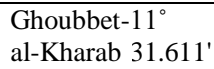 & $\begin{array}{l}42^{\circ} \\
31.422^{\prime}\end{array}$ & 0 & 8.15 & 28.5 & 28.8 & $--^{5}$ & 1.028 & 8.32 & 1.86 & $\begin{array}{l}\text { Ghoubbet-al- } \\
\text { Kharab }\end{array}$ \\
\hline $2-1$ & $\begin{array}{l}\text { Site lake water } \\
2-1\end{array}$ & $\begin{array}{r}\text { Lake Asal } 11^{\circ} \\
36.319^{\prime}\end{array}$ & $\begin{array}{l}42^{\circ} \\
24.866^{\prime}\end{array}$ & -150 & 7.01 & 33.7 & 33.9 & - & 1.212 & 4.00 & 0.55 & $\begin{array}{l}\text { Lake Asal, } \\
\text { southern shore, } \\
\text { orange-black } \\
\text { mictobial mat }\end{array}$ \\
\hline $\begin{array}{l}2-1- \\
\text { nov }\end{array}$ & $\begin{array}{l}\text { Site lake water } \\
2-1\end{array}$ & Lake Asal - “ - & $-“-$ & -151 & 6.63 & 35.4 & - & 2.04 & - & 8.80 & - & $-“-$ \\
\hline $2-2$ & $\begin{array}{l}\text { Site hot pond } \\
2-2 \text { water }\end{array}$ & $\begin{array}{r}\text { Lake Asal } 11^{\circ} \\
36.319^{\prime}\end{array}$ & $\begin{array}{l}42^{\circ} \\
24.866^{\prime}\end{array}$ & -125 & 7.75 & 31.2 & - & - & - & 3.20 & - & $\begin{array}{l}\text { small water } \\
\text { pond with tiny } \\
\text { fishes, } 200 \mathrm{~m} \\
\text { off Lake Asal, } \\
\text { southern shore }\end{array}$ \\
\hline 3 & $\begin{array}{l}\text { Site hydrothermal } \\
3 \text { fluid }\end{array}$ & $\begin{array}{r}\text { Lake Asal } 11^{\circ} \\
36.225^{\prime}\end{array}$ & $\begin{array}{l}42^{\circ} \\
24.843^{\prime}\end{array}$ & -125 & 6.93 & 77.0 & 77.0 & - & 1.026 & 0.08 & 0.36 & $\begin{array}{l}\text { hot spring } \\
\text { Korili }\end{array}$ \\
\hline 3 -nov & $\begin{array}{l}\text { Site hydrothermal } \\
3 \text { fluid }\end{array}$ & Lake Asal - “- & $-“-$ & - “- & 6.70 & 76.7 & - & 0.35 & 1.032 & 0.00 & 0.41 & $-“-$ \\
\hline $3-1$ & $\begin{array}{l}\text { Site hot pond } \\
3-1 \text { water }\end{array}$ & $\begin{array}{r}\text { Lake Asal } 11^{\circ} \\
36.206^{\prime}\end{array}$ & $\begin{array}{l}42^{\circ} \\
24.838^{\prime}\end{array}$ & -125 & 8.20 & 34.2 & - & - & & 8.70 & - & $\begin{array}{l}\text { small pond } \sim 50 \\
\text { m upstream } \\
\text { from site } 3 \\
\text { (inhabited by } \\
\text { tiny fishes) }\end{array}$ \\
\hline $\begin{array}{l}3-1- \\
\text { nov }\end{array}$ & $\begin{array}{l}\text { Site hot pond } \\
3-1 \text { water }\end{array}$ & Lake Asal - “ - & - “- & -“- & 7.73 & 34.3 & 34.2 & ८ 59 & 1.026 & 4.39 & 0.68 & $-"-$ \\
\hline $3-2$ & $\begin{array}{l}\text { Site creek water } \\
3-2\end{array}$ & $\begin{array}{r}\text { Lake Asal } 11^{\circ} \\
36.227^{\prime}\end{array}$ & $\begin{array}{l}42^{\circ} \\
24.825^{\prime}\end{array}$ & -127 & 7.39 & 52.0 & & & - & 7.86 & - & $\begin{array}{l}\text { creek } \sim 40 \mathrm{~m} \\
\text { downstream } \\
\text { from site } 3\end{array}$ \\
\hline 4 & $\begin{array}{l}\text { Site lake water } \\
4 \begin{array}{l}\text { over the salt } \\
\text { plane }\end{array}\end{array}$ & $\begin{array}{r}\text { Lake Asal } 11^{\circ} \\
37.309^{\prime}\end{array}$ & $\begin{array}{l}42^{\circ} \\
23.749^{\prime}\end{array}$ & -150 & 7.03 & 27.7 & 27., & - & - & 1.90 & - & $\begin{array}{l}\text { Lake Asal, SW } \\
\text { shore, bright } \\
\text { white salt } \\
\text { crystal plane }\end{array}$ \\
\hline 5 & $\begin{array}{l}\text { Site hydrothermal } \\
5 \text { fluid }\end{array}$ & $\begin{array}{r}\text { Lake Asal } 11^{\circ} \\
36.777^{\prime}\end{array}$ & $\begin{array}{l}42^{\circ} \\
25.569^{\prime}\end{array}$ & -140 & 7.24 & 39.3 & 39.0 & - & 1.040 & 6.30 & 0.95 & hot spring \\
\hline $5-2$ & $\begin{array}{l}\text { Site hydrothermal } \\
5-2 \text { fluid }\end{array}$ & $\begin{array}{r}\text { Lake Asal } 11^{\circ} \\
36.777^{\prime}\end{array}$ & $\begin{array}{l}42^{\circ} \\
25.569^{\prime}\end{array}$ & -140 & - & - & - & - & - & - & - & $\begin{array}{l}\text { hot spring, a } \\
\text { few meters east } \\
\text { from site } 5\end{array}$ \\
\hline 6 & $\begin{array}{l}\text { Site hydrothermal } \\
6 \text { fluid }\end{array}$ & $\begin{array}{r}\text { Lake Asal } 11^{\circ} \\
36.790^{\prime}\end{array}$ & $\begin{array}{l}42^{\circ} \\
25.600^{\prime}\end{array}$ & & 7.35 & 41.1 & - & - & 1.038 & 6.00 & 0.90 & $\begin{array}{l}\text { hot spring, } \\
\text { midstream }\end{array}$ \\
\hline 7 & $\begin{array}{l}\text { Site lake water } \\
7\end{array}$ & $\begin{array}{r}\text { Lake Asal } 11^{\circ} \\
36.853^{\prime}\end{array}$ & $\begin{array}{l}42^{\circ} \\
24<3 \prime\end{array}$ & -15 & 6.85 & 30.9 & 31.2 & - & - & 4.56 & - & $\begin{array}{l}\text { Lake Asal, } \\
\text { southern shore, } \\
\text { transparent } \\
\text { crystals (salt?) } \\
\text { with reddish } \\
\text { mat }\end{array}$ \\
\hline 7-nov & $\begin{array}{l}\text { Site lake water } \\
7\end{array}$ & Lake Asal - " - & & -“- & 6.71 & 32.5 & - & 1.94 & - & 6.00 & - & -“- \\
\hline $\begin{array}{l}\mathrm{C} 1-5 \\
(0 \mathrm{~m})\end{array}$ & C1 lake water & $\begin{aligned} \text { La. As. }{ }^{1} 11^{\circ} \\
\text { ग. } 226^{\prime}\end{aligned}$ & $\begin{array}{l}42^{\circ} \\
24.663^{\prime}\end{array}$ & -150 & 6.77 & 27.3 & - & 2.08 & 1.212 & - & 3.14 & $\begin{array}{l}\text { water column } \\
\text { sampling site } 1 \text {, } \\
0 \mathrm{~m} \text { depth }\end{array}$ \\
\hline $\begin{array}{l}\mathrm{C} 1-4 \\
(5 \mathrm{~m})\end{array}$ & C1 lake water & Lake ..... - “ - & $-“-$ & $-“-$ & 6.75 & 26.9 & - & 2.08 & - & - & - & $\begin{array}{l}\text { water column } \\
\text { sampling site } 1 \text {, } \\
5 \mathrm{~m} \text { depth }\end{array}$ \\
\hline $\begin{array}{l}\text { C1-3 } \\
(10 \mathrm{~m})\end{array}$ & C1 lake water & Lake Asal - “- & $-“-$ & - “- & 6.89 & 25.1 & - & 2.12 & - & - & - & $\begin{array}{l}\text { water column } \\
\text { sampling site } 1 \text {, } \\
10 \mathrm{~m} \text { depth }\end{array}$ \\
\hline $\begin{array}{l}\text { C1-2 } \\
(15 \mathrm{~m})\end{array}$ & C1 lake water & Lake Asal - “ - & - “- & $-“-$ & 6.55 & 28.3 & - & 2.12 & - & - & - & $\begin{array}{l}\text { water column } \\
\text { sampling site } 1 \text {, } \\
15 \mathrm{~m} \text { depth }\end{array}$ \\
\hline $\begin{array}{l}\text { C1-1 } \\
(23 \mathrm{~m})\end{array}$ & C1 lake water & Lake Asal - “ - & $-“-$ & $-“-$ & 6.54 & 27.4 & - & 2.25 & 1.213 & - & 3.49 & $\begin{array}{l}\text { water column } \\
\text { sampling site } 1 \text {, } \\
23 \text { depth }\end{array}$ \\
\hline $\begin{array}{l}\mathrm{C} 2-4 \\
(0 \mathrm{~m})\end{array}$ & C2 lake water & $\begin{array}{r}\text { Lake Asal } 11^{\circ} \\
38.738^{\prime}\end{array}$ & $\begin{array}{l}42^{\circ} \\
25.457^{\prime}\end{array}$ & -151 & 6.81 & 27.5 & - & 2.10 & - & - & - & $\begin{array}{l}\text { water column } \\
\text { sampling site } 2 \text {, } \\
0 \text { m depth }\end{array}$ \\
\hline $\begin{array}{l}\mathrm{C} 2-3 \\
(5 \mathrm{~m})\end{array}$ & C2 lake water & Lake Asal - “ - & - “- & $-“-$ & 6.82 & 27.3 & - & 2.06 & - & - & - & $\begin{array}{l}\text { water column } \\
\text { sampling site } 2, \\
5 \text { m depth }\end{array}$ \\
\hline $\begin{array}{l}\mathrm{C} 2-2 \\
(10 \mathrm{~m})\end{array}$ & C2 lake water & Lake Asal - “ - & $-“-$ & $-“-$ & 6.81 & 27.1 & - & 2.12 & - & - & - & $\begin{array}{l}\text { water column } \\
\text { sampling site 2, }\end{array}$ \\
\hline
\end{tabular}




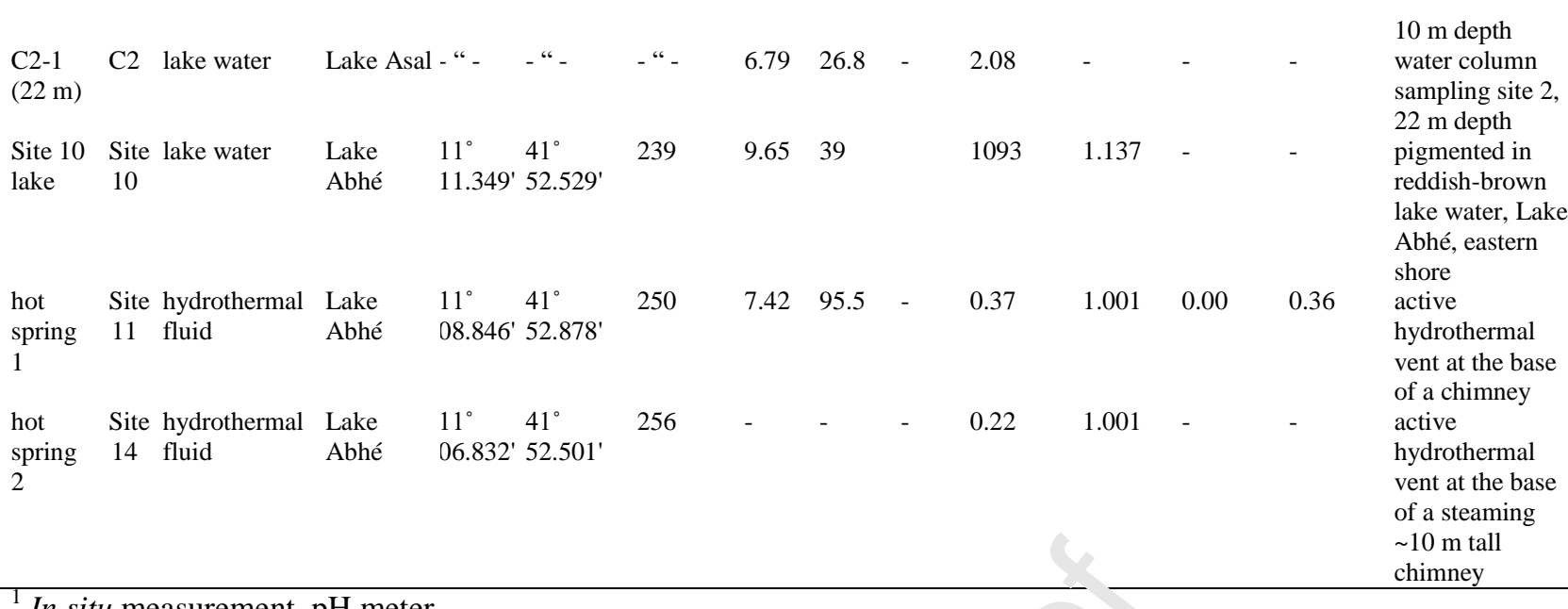

In situ measurement, $\mathrm{pH}$ meter.
2 In situ measurement, DO meter.

${ }^{3} \mathrm{DO}=$ dissolved oxygen.

${ }^{4} \mathrm{DIC}=$ dissolved inorganic carbon.

${ }^{5}$ Not measured.

Table 2 Mineralogy (XRD) of the investigated spires from the Afar ? ift.

\begin{tabular}{|c|c|c|}
\hline $\begin{array}{l}\text { Sample } \\
\text { ID }^{1}\end{array}$ & Location & Mineralogy $^{2}$ \\
\hline LAs-1 & $\begin{array}{l}\text { Lake } \\
\text { Asal }\end{array}$ & aragonite, low-Mg calcite $\left(2 . \Gamma_{\text {.1. }} 1 . \iota / \mathrm{MgCO}_{3}\right)$, low-Mg calcite $\left(2.3 \mathrm{~mol} . \% \mathrm{MgCO}_{3}\right)$ \\
\hline LAs-2 & $-“$ & $\begin{array}{l}\text { aragonite }(42 \%) \text {, low- } \mathrm{M}_{c} \text { calcite }\left(\angle .0 \mathrm{~mol} . \% \mathrm{MgCO}_{3}\right)(41 \%), \text { low-Mg calcite }(2.4 \mathrm{~mol} . \% \\
\left.\mathrm{MgCO}_{3}\right)(17 \%)\end{array}$ \\
\hline LAs-3 & $-“$ & low-Mg calcite $\left(3.0 \mathrm{~mol} . \% \mathrm{MgCO}_{3}\right)$, aragonite, calcite \\
\hline $\begin{array}{l}\text { LAs- } \\
\text { salt }\end{array}$ & - “ - & halite, gypsum (1 ac. s) \\
\hline LAb-1 & $\begin{array}{l}\text { Lake } \\
\text { Abhé }\end{array}$ & low-Mg calci (1.1 mol. $\left.\% \mathrm{MgCO}_{3}\right)(65 \%)$, low-Mg calcite (3.4 mol.\% $\left.\mathrm{MgCO}_{3}\right)(35 \%)$ \\
\hline LAb-2 & $-“$ & low-Mg alcite $\left(1.5 \mathrm{~mol} . \% \mathrm{MgCO}_{3}\right)(60 \%)$, low-Mg calcite $\left(2.6 \mathrm{~mol} . \% \mathrm{MgCO}_{3}\right)(40 \%)$ \\
\hline LAb-3 & $-“$ & $\begin{array}{l}\text { high-Mg calcite }\left(4.5 \mathrm{~mol} . \% \mathrm{MgCO}_{3}\right) \text {, high-Mg calcite }\left(5.1 \mathrm{~mol} . \% \mathrm{MgCO}_{3}\right) \text {, low-Mg calcite (0.9 } \\
\left.\text { mol. } \% \mathrm{MgCO}_{3}\right)\end{array}$ \\
\hline LAb-4 & $-“-$ & low-Mg calcite $\left(1.2\right.$ mol. $\left.\% \mathrm{MgCO}_{3}\right)(77 \%)$, low-Mg calcite $\left(1.3\right.$ mol. $\left.\% \mathrm{MgCO}_{3}\right)(23 \%)$ \\
\hline $\mathrm{LAb}-5$ & $-“$ & $\begin{array}{l}\text { high- } \mathrm{Mg} \text { calcite }\left(4.0 \mathrm{~mol} \% \mathrm{MgCO}_{3}\right)(72 \%) \text {, low-Mg calcite }\left(0.8 \mathrm{~mol} . \% \mathrm{MgCO}_{3}\right)(20 \%) \text {, high- } \\
\text { Mg calcite }\left(6.4 \mathrm{~mol} . \% \mathrm{MgCO}_{3}\right)(8 \%)\end{array}$ \\
\hline LAb-6 & - “- & $\begin{array}{l}\text { high- } \mathrm{Mg} \text { calcite }\left(4.0 \mathrm{~mol} \% \mathrm{MgCO}_{3}\right)(72 \%) \text {, low-Mg calcite }\left(0.8 \text { mol. } \% \mathrm{MgCO}_{3}\right)(20 \%) \text {, high- } \\
\text { Mg calcite }\left(6.4 \mathrm{~mol} . \% \mathrm{MgCO}_{3}\right)(8 \%)\end{array}$ \\
\hline LAb-7 & - “ - & $\begin{array}{l}\text { high- } \mathrm{Mg} \text { calcite }\left(4.0 \mathrm{~mol} \% \mathrm{MgCO}_{3}\right)(72 \%) \text {, low- } \mathrm{Mg} \text { calcite }\left(0.8 \mathrm{~mol} . \% \mathrm{MgCO}_{3}\right)(20 \%) \text {, high- } \\
\text { Mg calcite }\left(6.4 \mathrm{~mol} . \% \mathrm{MgCO}_{3}\right)(8 \%)\end{array}$ \\
\hline LAb-8 & - “ & high-Mg calcite $\left(4.0\right.$ mol. $\left.\% \mathrm{MgCO}_{3}\right)(100 \%)$ \\
\hline
\end{tabular}

${ }^{1}$ For sample positions across the spire wall see Figure 3. 
${ }^{2} \mathrm{MgCO}_{3}$ (in mol. \%) in calcite crystal lattice was calculated using $\mathrm{d}_{104}$ values and the approach of Goldsmith and Graf (1958).

Table 3 Chemical composition of the investigated spires from the Afar Rift.

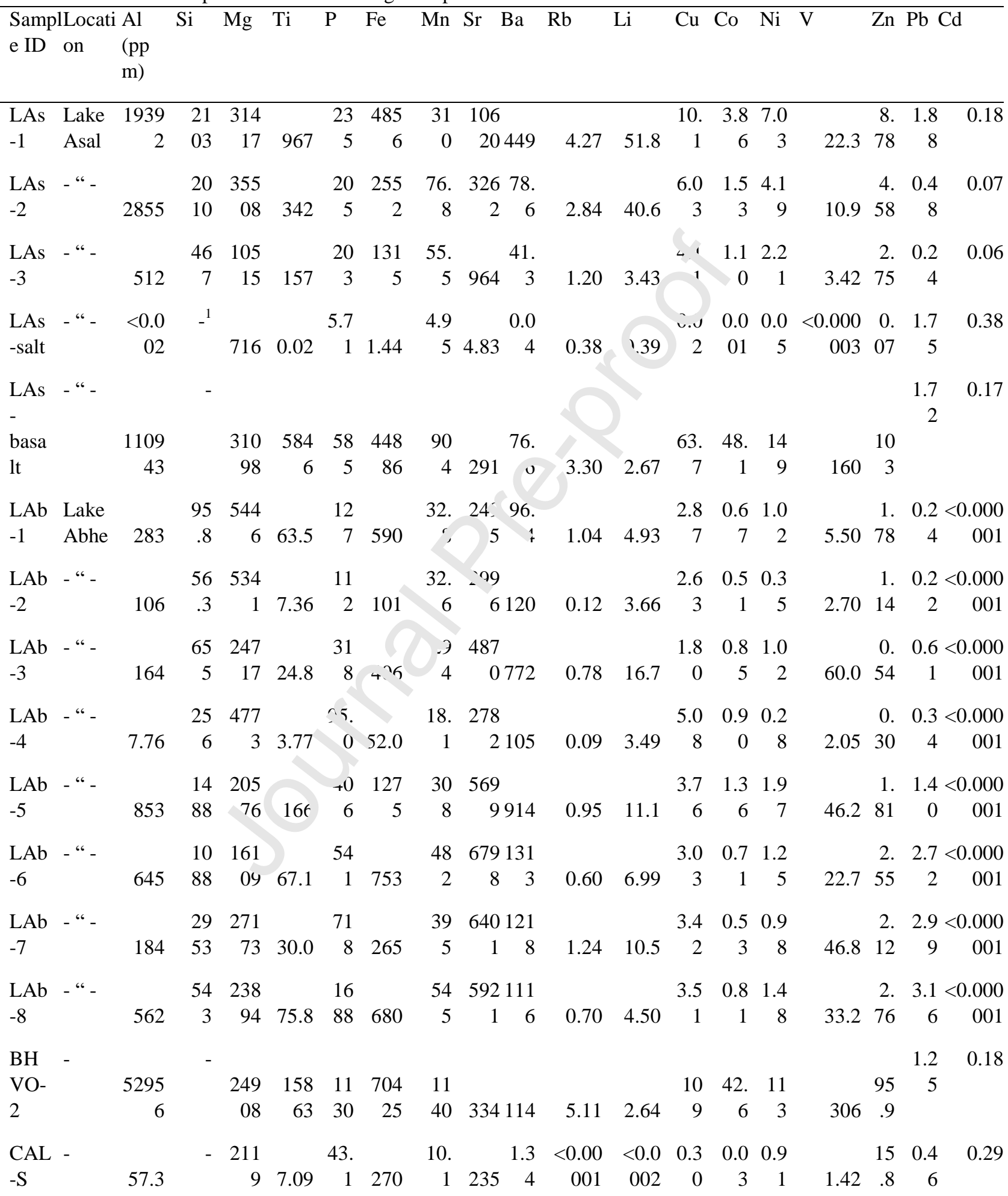

\footnotetext{
${ }^{1}$ Not measured.
} 


\begin{tabular}{|c|c|c|c|c|c|c|c|c|c|c|c|c|c|c|c|}
\hline \multicolumn{3}{|c|}{$\begin{array}{l}\text { Samp Locati Mo } \\
\text { le ID on } \\
\begin{aligned}(\mathrm{pp} \\
\mathrm{m})\end{aligned}\end{array}$} & $\mathrm{Tl}$ & $\mathrm{Cr}$ & $\mathrm{W}$ & & Sc & $\mathrm{Hf}$ & $\mathrm{h}$ & $\mathrm{U}$ & $\mathrm{La}$ & $\mathrm{Ce} \mathrm{P}$ & \multicolumn{3}{|c|}{$\mathrm{Nd} \quad \mathrm{Sm}$} \\
\hline LAs & Lake & 0.30 & 0.20 & 9.7 & 0.37 & 1.59 & 5.99 & 2.63 & 1.75 & 8.34 & 12.611 .5 & 23.7 & & & 2.35 \\
\hline-1 & Asal & & & 3 & & & & & & & & & 2.75 & 11.3 & \\
\hline LAs & - “- & 0.16 & $<0.00$ & 5.2 & $<0.00$ & 0.86 & $<0.00$ & $<0.00$ & 0.24 & 5.91 & 1.361 .38 & 3.03 & & & 0.30 \\
\hline-2 & & & 001 & 3 & 002 & & 001 & 02 & & & & & 0.36 & 1.47 & \\
\hline LAs & - “- & 0.07 & $<0.00$ & 3.3 & $<0.00$ & 0.42 & $<0.00$ & $<0.00$ & 0.06 & 3.05 & 0.260 .27 & 0.61 & & & 0.06 \\
\hline-3 & & & 001 & 6 & 002 & & 001 & 02 & & & & & 0.07 & 0.28 & \\
\hline LAs & - “- & 0.02 & $<0.00$ & 0.0 & $<0.00<$ & .0000 & $<0.00$ & $<0.000$ & .0004 & $<0.000$ & $<0.0,700.00$ & 0.00 & $<0.0000$ & 0.00 & .0000 \\
\hline -salt & & & 001 & 8 & 002 & 003 & 001 & 02 & & 003 & ¿'2 02 & 04 & 0002 & 02 & 001 \\
\hline LAs & - “- & 0.36 & $<0.00$ & 16 & 243 & 15.2 & 15.2 & 2.42 & 0.82 & 0.2 ; & 1 .96 .16 & 14.6 & & & 2.12 \\
\hline- & & & 001 & 2 & & & & & & & & & & & \\
\hline $\begin{array}{l}\text { basa } \\
\text { lt }\end{array}$ & & & & & & & & & & & & & 1.92 & 8.73 & \\
\hline LAb & Lake & 0.06 & $<0.00$ & 1.0 & $<0.00$ & 0.17 & $<0.00$ & $<0.00$ & $0 . \mathrm{j}^{\mathrm{j}}$ & า.73 & 0.620 .23 & 0.82 & & & 0.07 \\
\hline-1 & Abhe & & 001 & 5 & 002 & & 001 & 02 & & & & & 0.07 & 0.30 & \\
\hline LAb & - “- & 0.24 & $<0.00$ & 0.7 & $<0.00$ & 0.02 & $<0.00$ & $<0.10$ & u. 49 & 0.78 & 2.790 .46 & 3.10 & & & 0.19 \\
\hline-2 & & & 001 & 2 & 002 & & $0 r_{1}$ & 02 & & & & & 0.16 & 0.72 & \\
\hline LAb & - “- & 0.06 & $<0.00$ & 1.0 & $<0.00$ & 0.13 & $<0.00$ & ๆ.00 & 3.03 & 2.18 & 24.38 .30 & 51.9 & & & 3.18 \\
\hline-3 & & & 001 & 6 & 002 & & ๆา1 & 02 & & & & & 2.89 & 13.1 & \\
\hline LAb & - “- & 0.09 & $<0.00$ & 0.1 & $<0.00$ & $0.6:$ & 0.00 & $<0.00$ & 0.06 & 0.80 & 0.280 .06 & 0.49 & & & 0.02 \\
\hline-4 & & & 001 & 9 & 002 & & J01 & 02 & & & & & 0.02 & 0.09 & \\
\hline LAb & - “- & 1.04 & $<0.00$ & 2.9 & $<0.00$ & $0 . \angle 9$ & $<0.00$ & $<0.00$ & 3.27 & 1.36 & 33.810 .0 & 57.6 & & & 4.04 \\
\hline-5 & & & 001 & 5 & $00_{\angle}$ & & 001 & 02 & & & & & 3.58 & 16.3 & \\
\hline LAb & - “- & 0.74 & $<0.00$ & 1.3 & $\therefore 0$ & 0.17 & $<0.00$ & $<0.00$ & 3.40 & 0.67 & 40.917 .1 & 83.4 & & & 6.38 \\
\hline-6 & & & 001 & 0 & 0,2 & & 001 & 02 & & & & & 5.91 & 26.5 & \\
\hline $\mathrm{LAb}$ & - “- & 1.82 & $<0.00$ & 1.0 & $<0.00$ & 0.12 & $<0.00$ & $<0.00$ & 3.35 & 0.42 & 38.513 .7 & 53.9 & & & 5.26 \\
\hline-7 & & & 001 & 0 & 002 & & 001 & 02 & & & & & 4.81 & 21.7 & \\
\hline $\mathrm{LAb}$ & - “- & 1.23 & $<0.00$ & 1.4 & $<0.00$ & 0.19 & $<0.00$ & $<0.00$ & 4.10 & 1.41 & 30.915 .8 & 83.3 & & & 5.57 \\
\hline-8 & & & 001 & 8 & 002 & & 001 & 02 & & & & & 5.36 & 23.7 & \\
\hline BH & - & 3.58 & $<0.00$ & 26 & 0.34 & 18.5 & 15.2 & 4.61 & 0.61 & 0.45 & 12.713 .0 & 32.4 & & & 4.94 \\
\hline 2 & & & 001 & 1 & & & & & & & & & 4.56 & 21.1 & \\
\hline CAL & - & 0.17 & $<0.00$ & 2.3 & $<0.00$ & 0.02 & $<0.00$ & & $<0.00$ & 0.93 & 1.240 .53 & 0.21 & & & 0.04 \\
\hline$-S$ & & & 001 & 4 & 002 & & 001 & & 001 & & & & 0.06 & 0.25 & \\
\hline
\end{tabular}

Table 3 (continued) 


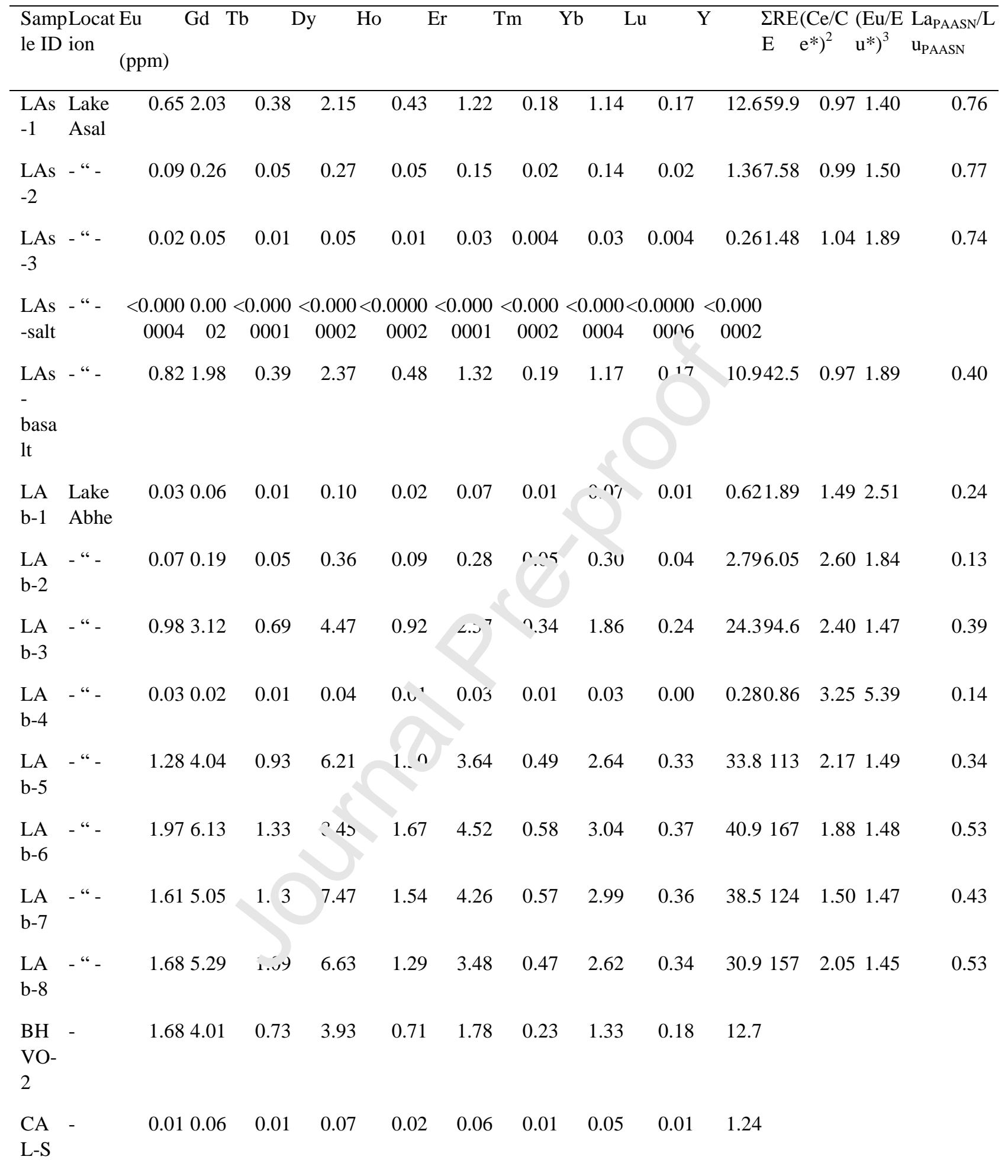

${ }^{2} \mathrm{Ce} / \mathrm{Ce} *=2 \mathrm{Ce}_{\mathrm{PAASN}} /\left(\mathrm{La}_{\mathrm{PAASN}}+\operatorname{Pr}_{\mathrm{PAASN}}\right)$.

${ }^{3} \mathrm{Eu} / \mathrm{Eu}^{*}=2 \mathrm{Eu}_{\text {PAASN }} /\left(\mathrm{Sm}_{\text {PAASN }}+\mathrm{Gd}_{\text {PAASN }}\right)$.

Table 4 Major element concentrations (XRF) of basalt and salt (evaporite) from the Lake Asal. Sample Measured as oxides Recalculated as chlorides and 


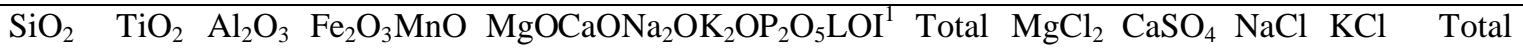
(wt.\%)

\begin{tabular}{|c|c|c|c|c|c|c|c|c|c|c|c|}
\hline $\begin{array}{l}\text { LAs- } \\
\text { basalt }\end{array}$ & $\begin{array}{ll}47.6 & 0.95\end{array}$ & 21.9 & $\begin{array}{lll}7.62 & 0.12\end{array}$ & 5.8713 .9 & 1.920 .200 .14 & $\begin{array}{ll}-^{2} & 100.1\end{array}$ & - & - & - & - & \\
\hline $\begin{array}{l}\text { LAs- } \\
\text { salt }\end{array}$ & $0.00 \quad 0.00$ & 0.00 & 0.000 .00 & 0.210 .07 & 51.50 .030 .00 & - $\quad 51.8$ & 0.51 & 0.17 & 97.1 & 0.04 & 97.9 \\
\hline
\end{tabular}

${ }^{1}$ At $1050^{\circ}$ Cfor 2 hours.

${ }^{2}$ Not measured.

Table 5 Chemical composition of the investigated fluid samples from the Afar Rift ${ }^{1}$.

\begin{tabular}{|c|c|c|c|c|c|c|c|c|c|c|c|c|c|c|c|c|}
\hline $\begin{array}{l}\text { Sampl } \\
\text { e ID }\end{array}$ & $\begin{array}{l}\text { ISit } \\
\text { e } \\
\text { ID }\end{array}$ & Location & Sample type & $\begin{array}{l}\mathrm{Na} \\
\text { (ppm } \\
)\end{array}$ & $\mathrm{K}$ & $\mathrm{Si}$ & $\mathrm{Mg}$ & $\mathrm{Ca}$ & $\begin{array}{l}(\mathrm{Mg} / \mathrm{Ca})_{\mathrm{m}} \\
\text { ol }\end{array}$ & $\mathrm{Cl}$ & $\bar{B} r$ & $\mathrm{SO}_{4}$ & $\mathrm{NO}_{3}$ & $\begin{array}{l}\mathrm{Fe} \\
(\mathrm{ppb} \\
)\end{array}$ & $\mathrm{Mn}$ & $\mathrm{Cu}$ \\
\hline s & $\begin{array}{l}\text { Sit } \\
\text { e } 1\end{array}$ & $\begin{array}{l}\text { Ghoubbet } \\
\text {-al- } \\
\text { Kharab }\end{array}$ & seawater & $\begin{array}{r}1031 \\
9\end{array}$ & 518 & $-^{2}$ & $\begin{array}{r}130 \\
0\end{array}$ & 397 & 5.40 & $\overline{195}, \overline{-}$ & - & 2768 & - & - & - & - \\
\hline $\begin{array}{l}\mathrm{C} 1-5 \\
(0 \mathrm{~m})\end{array}$ & $\mathrm{C} 1$ & $\begin{array}{l}\text { Lake } \\
\text { Asal }\end{array}$ & lake water & $\begin{array}{r}6479 \\
4\end{array}$ & $\begin{array}{r}392 \\
9\end{array}$ & $\begin{array}{r}6.0 \\
8\end{array}$ & $\begin{array}{r}870 \\
2\end{array}$ & $\begin{array}{r}214 \\
0\end{array}$ & 671 & $\begin{array}{r}29043 \\
8\end{array}$ & 880 & 3830 & $\begin{array}{r}0.12 \\
0\end{array}$ & 23.9 & 1674 & $\begin{array}{r}12 . \\
2\end{array}$ \\
\hline $\begin{array}{l}\mathrm{C} 1-4 \\
(5 \mathrm{~m})\end{array}$ & $\mathrm{C} 1$ & $\begin{array}{l}\text { Lake } \\
\text { Asal }\end{array}$ & lake water & - & - & $\begin{array}{r}6.0 \\
7\end{array}$ & & & - & $\begin{array}{r}27278 \\
1\end{array}$ & 876 & 3373 & $\begin{array}{r}0.19 \\
5\end{array}$ & 3.21 & 706 & $\begin{array}{r}11 . \\
7\end{array}$ \\
\hline $\begin{array}{l}\mathrm{C} 1-3 \\
(10 \mathrm{~m})\end{array}$ & $\mathrm{C} 1$ & $\begin{array}{l}\text { Lake } \\
\text { Asal }\end{array}$ & lake water & - & - & $\begin{array}{r}6.1 \\
0\end{array}$ & & - & - & $\begin{array}{r}27433 \\
3\end{array}$ & 885 & 3647 & $\begin{array}{r}0.11 \\
5\end{array}$ & 3.67 & 427 & $\begin{array}{r}12 . \\
0\end{array}$ \\
\hline $\begin{array}{l}\mathrm{C} 1-2 \\
(15 \mathrm{~m})\end{array}$ & $\mathrm{C} 1$ & $\begin{array}{l}\text { Lake } \\
\text { Asal }\end{array}$ & lake water & - & - & 6.0 & & - & - & $\begin{array}{r}27643 \\
9\end{array}$ & 874 & 3221 & $\begin{array}{r}0.12 \\
1\end{array}$ & 3.18 & 1064 & $\begin{array}{r}12 . \\
8\end{array}$ \\
\hline $\begin{array}{l}\mathrm{C} 1-1 \\
(23 \mathrm{~m})\end{array}$ & $\mathrm{C} 1$ & $\begin{array}{l}\text { Lake } \\
\text { Asal }\end{array}$ & lake water & $\begin{array}{r}6486 \\
0\end{array}$ & 391 & $\begin{array}{r}1 \\
5\end{array}$ & $\begin{array}{r}869 \\
9\end{array}$ & $\begin{array}{r}214 \\
1\end{array}$ & 6.70 & $\begin{array}{r}27310 \\
2\end{array}$ & 889 & 3275 & $\begin{array}{r}0.21 \\
9\end{array}$ & 4.69 & 878 & $\begin{array}{r}11 . \\
7\end{array}$ \\
\hline $\begin{array}{l}\mathrm{C} 2-4 \\
(0 \mathrm{~m})\end{array}$ & $\mathrm{C} 2$ & $\begin{array}{l}\text { Lake } \\
\text { Asal }\end{array}$ & lake water & & & - & - & - & - & $\begin{array}{r}26204 \\
2\end{array}$ & - & 3825 & $\begin{array}{r}0.29 \\
6\end{array}$ & 3.36 & 832 & $\begin{array}{r}12 . \\
0\end{array}$ \\
\hline $\begin{array}{l}\mathrm{C} 2-3 \\
(5 \mathrm{~m})\end{array}$ & $\mathrm{C} 2$ & $\begin{array}{l}\text { Lake } \\
\text { Asal }\end{array}$ & lake water & & & - & - & - & - & $\begin{array}{r}26665 \\
3\end{array}$ & - & 3207 & $\begin{array}{r}0.15 \\
1\end{array}$ & 4.10 & 1250 & $\begin{array}{r}11 . \\
7\end{array}$ \\
\hline $\begin{array}{l}\mathrm{C} 2-2 \\
(10 \mathrm{~m})(\end{array}$ & $\mathrm{C} 2$ & $\begin{array}{l}\text { Lake } \\
\text { Asal }\end{array}$ & lake water & 3 & - & - & - & - & - & $\begin{array}{r}24572 \\
8\end{array}$ & - & 2995 & $\begin{array}{r}0.11 \\
4\end{array}$ & 4.89 & 1416 & $\begin{array}{r}11 . \\
8\end{array}$ \\
\hline $\begin{array}{l}\mathrm{C} 2-1 \\
(22 \mathrm{~m})\end{array}$ & $\mathrm{C} 2$ & $\begin{array}{l}\text { Lake } \\
\text { Asal }\end{array}$ & lake water & - & - & - & - & - & - & $\begin{array}{r}24682 \\
7\end{array}$ & - & 3167 & $\begin{array}{r}0.12 \\
3\end{array}$ & 15.5 & 992 & $\begin{array}{r}11 . \\
6\end{array}$ \\
\hline $\begin{array}{l}3-1- \\
\text { nov }\end{array}$ & $\begin{array}{l}\text { Sit } \\
\text { e 3-1 } \\
1\end{array}$ & $\begin{array}{l}\text { Lake } \\
\text { Asal }\end{array}$ & $\begin{array}{l}\text { hot pond } \\
\text { water }\end{array}$ & 8908 & 467 & $\begin{array}{r}24 . \\
6\end{array}$ & 369 & $\begin{array}{r}311 \\
2\end{array}$ & 0.20 & 28716 & $\begin{array}{r}87 . \\
1\end{array}$ & 333 & $<0.1$ & 4.25 & 170 & $\begin{array}{r}0.7 \\
6\end{array}$ \\
\hline 3-nov & $\begin{array}{l}\text { Sit } \\
\text { e } 3\end{array}$ & $\begin{array}{l}\text { Lake } \\
\text { Asal }\end{array}$ & $\begin{array}{l}\text { hydrotherm } \\
\text { al fluid }\end{array}$ & 8532 & 463 & $\begin{array}{r}30 . \\
2\end{array}$ & 400 & $\begin{array}{r}273 \\
7\end{array}$ & 0.24 & 27216 & $\begin{array}{r}83 . \\
2\end{array}$ & 313 & $\begin{array}{r}0.47 \\
4\end{array}$ & 24.3 & 439 & $\begin{array}{r}5.3 \\
7\end{array}$ \\
\hline $\begin{array}{l}\text { Site } 10 \\
\text { lake }\end{array}$ & $\begin{array}{l}\text { Sit } \\
0 \mathrm{e} \\
10\end{array}$ & $\begin{array}{l}\text { Lake } \\
\text { Abhé }\end{array}$ & lake water & $\begin{array}{r}4934 \\
9\end{array}$ & $\begin{array}{r}132 \\
8\end{array}$ & $\begin{array}{r}64 . \\
2\end{array}$ & 2 & 2.80 & 1.18 & 57062 & - & $\begin{array}{r}2642 \\
8\end{array}$ & - & 154 & 14.6 & $\begin{array}{r}2.0 \\
5\end{array}$ \\
\hline $\begin{array}{l}\text { hot } \\
\text { spring } \\
1\end{array}$ & $\begin{array}{l}\text { Sit } \\
\mathrm{e} \\
11\end{array}$ & $\begin{array}{l}\text { Lake } \\
\text { Abhé }\end{array}$ & $\begin{array}{l}\text { hydrotherm } \\
\text { al fluid }\end{array}$ & 1264 & 47 & $\begin{array}{r}52 . \\
2\end{array}$ & 0.2 & 303 & - & 2016 & - & 336 & - & 1.20 & 4.19 & $\begin{array}{r}0.0 \\
3\end{array}$ \\
\hline
\end{tabular}




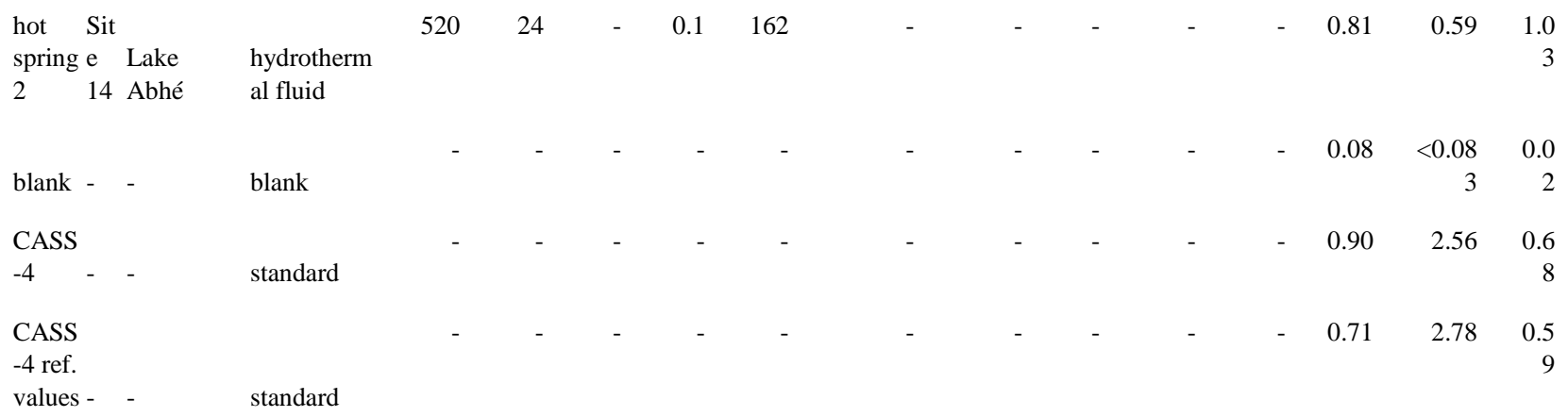

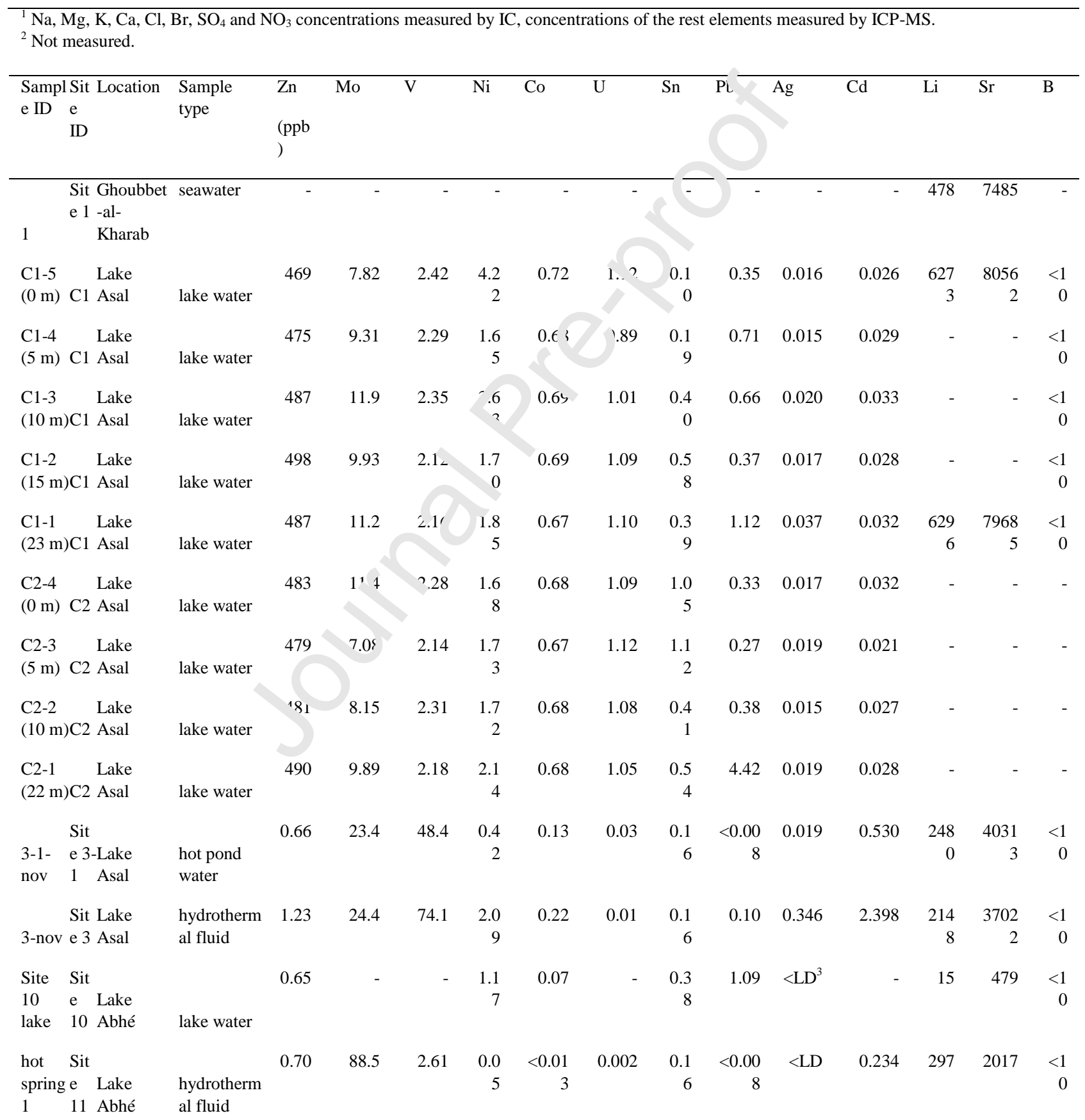




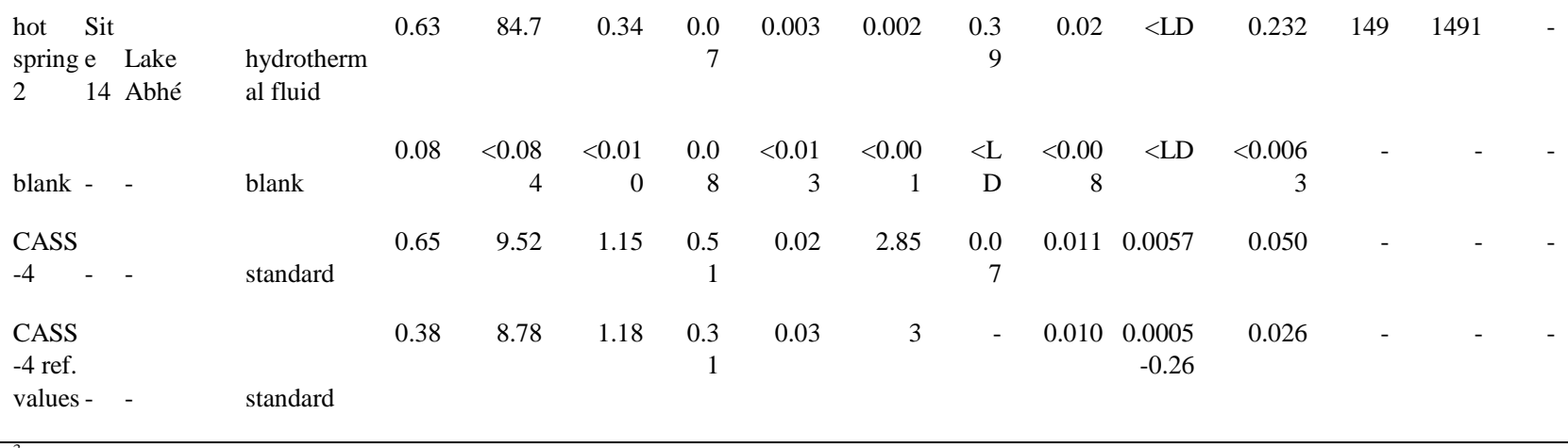

${ }^{3}$ Below the limits of detection.

Table 5 (continued)

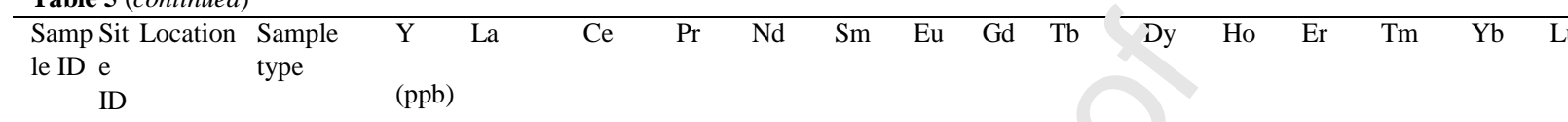

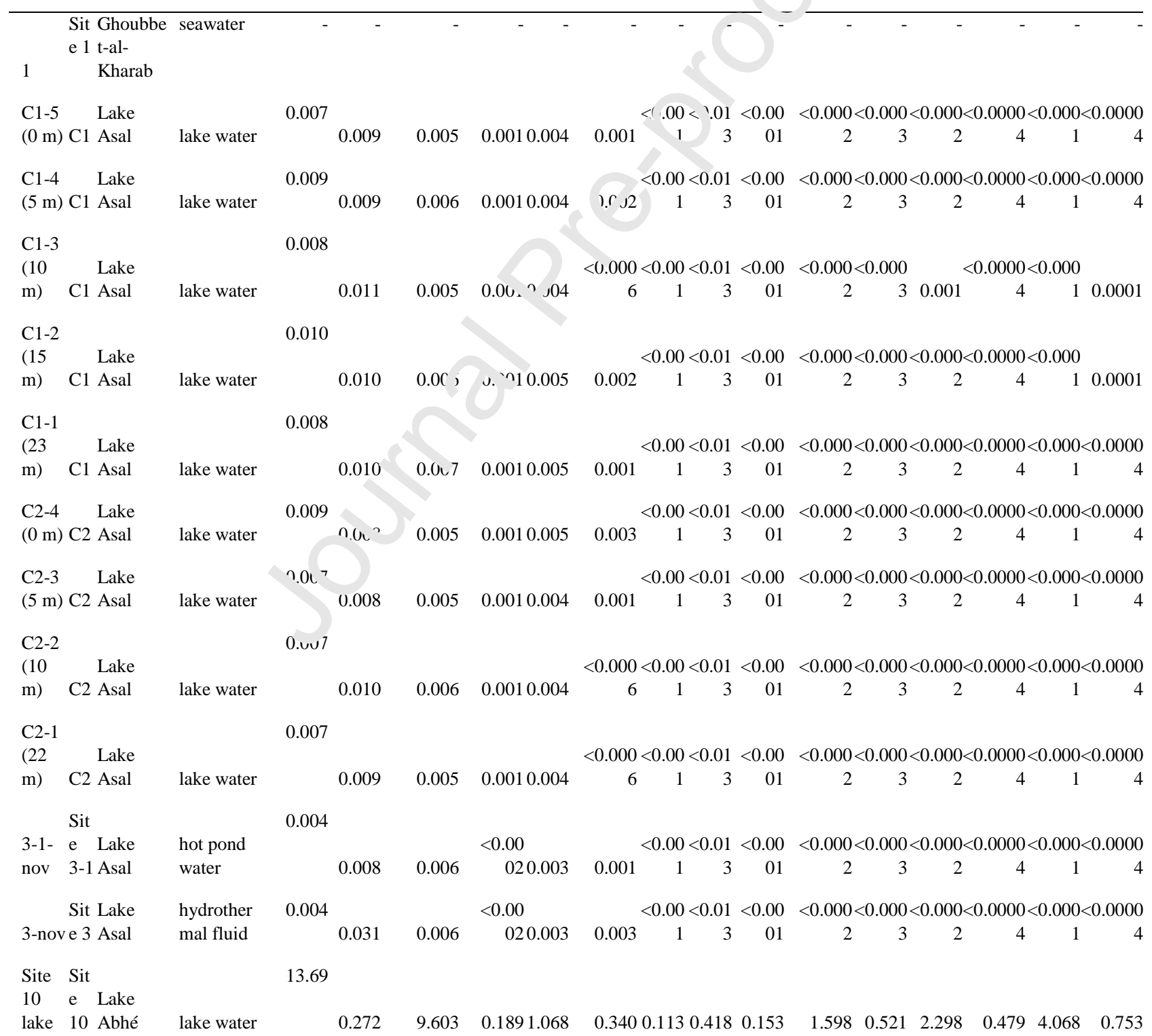


hot Sit

springe Lake

111 Abhé

hot Sit

springe Lake

214 Abhé

blank - - blank

CASS

$-4 \quad-\quad-\quad$ standard

CASS

-4 ref.

value

s -
0.001

hydrother mal fluid

hydrother mal fluid

0.008

0.010

$<0.00$
$<0.00<0.00<0.000<0.00<0.01<0.00<0.000<0.000<0.000<0.0000<0.000<0.0000$ $\begin{array}{llllllllllllll}0.001 & 0.002 & 02 & 1 & 6 & 1 & 3 & 01 & 2 & 3 & 2 & 4 & 1 & 4\end{array}$

$02<0.00<0.00<0.00<0.00<0.000<0.00<0.01<0.00<0.000<0.000<0.000<0.0000<0.000<0.0000$ $<0.00<0.00<0.00<0.00<0.00<0.000<0.00<0.01<0.00<0.000<0.000<0.000<0.0000<0.000<0.0000$ $\begin{array}{lllllllllllllll}02 & 03 & 05 & 02 & 1 & 6 & 1 & 3 & 01 & 2 & 3 & 2 & 4 & 1 & 4\end{array}$ $0.018 \quad 0.000<0.01$ $\begin{array}{lllllllllll}0.004 & 0.0010 .005 & 0.005 & 2 & 30.0002 & 0.001 & 0.0004 & 0.001 & 0.0002 & 0.001 & 0.0002\end{array}$ 0.000

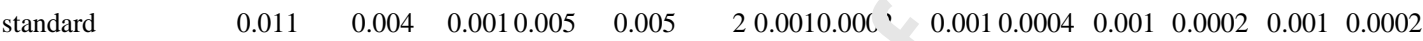

Table 6 Isotope composition of the investigated spires from the Afar Rift.

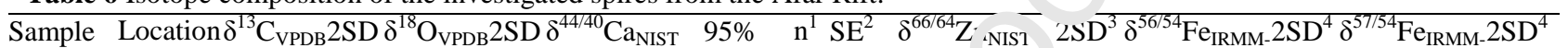
ID

(\%) $\quad(\%)(\%) \quad(\%)$ SRM-915a $(\%)$ conf.

(\%o) SRM 33 \%o) (\%o) $14(\%)$

(\%) ${ }_{14}(\%)$

(\%o)

(\%)

\begin{tabular}{|c|c|c|c|c|c|c|c|c|c|c|c|c|c|}
\hline LAs-1 & $\begin{array}{l}\text { Lake } \\
\text { Asal }\end{array}$ & 6.420 .04 & 3.680 .03 & 1.06 & 0.12 & 6 & $0 . \mathrm{C}$ & 0.21 & 0.07 & 0.07 & 0.07 & 0.08 & 0.16 \\
\hline LAs-2 & $-"$ - & 4.730 .01 & 2.020 .01 & 0.95 & 0.11 & 6 & J. 6 & 0.23 & 0.07 & 0.04 & 0.07 & 0.04 & 0.16 \\
\hline LAs-3 & - “ - & 3.890 .01 & 2.150 .03 & 0.22 & $7.6 c$ & 3 & 0.03 & 0.07 & 0.07 & -0.14 & 0.07 & -0.13 & 0.16 \\
\hline $\begin{array}{l}\text { LAs- } \\
\text { basalt }\end{array}$ & - “ - & -5 & - & & & - & - & - & - & 0.08 & 0.07 & 0.01 & 0.16 \\
\hline LAb-1 & $\begin{array}{l}\text { Lake } \\
\text { Abhe }\end{array}$ & 1.440 .04 & 0.070 .04 & & - & - & - & 0.06 & 0.07 & 0.07 & 0.07 & 0.13 & 0.16 \\
\hline LAb-2 & $-"$ - & 1.610 .02 & 0.220 .00 & - & - & - & - & -0.09 & 0.07 & 0.05 & 0.07 & 0.01 & 0.16 \\
\hline LAb-3 & 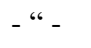 & 3.530 .01 & 4.120 .6$. & - & - & - & - & -0.22 & 0.07 & -0.22 & 0.07 & -0.36 & 0.16 \\
\hline LAb-4 & 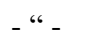 & 1.850 .01 & $1 . \ddots 0.0 \leq$ & - & - & - & - & - & - & - & - & - & \\
\hline LAb-5 & $-“-$ & 3.210 .03 & $4.17) .04$ & - & - & - & - & -0.04 & 0.07 & 0.01 & 0.07 & 0.05 & 0.16 \\
\hline LAb-6 & - “ - & 4.520 .02 & 5.140 .05 & - & - & - & - & 0.20 & 0.07 & -0.09 & 0.07 & -0.07 & 0.16 \\
\hline LAb-7 & - “ - & 4.620 .01 & 4.880 .07 & - & - & - & - & -0.23 & 0.07 & & - & - & \\
\hline LAb-8 & - “- & 3.410 .02 & 6.060 .04 & - & - & - & - & - & - & -0.14 & 0.07 & -0.25 & 0.16 \\
\hline $\begin{array}{l}\text { BHVO- } \\
2\end{array}$ & - & - & - & - & - & - & - & 0.18 & 0.07 & 0.04 & 0.07 & 0.06 & 0.16 \\
\hline
\end{tabular}

${ }^{1}$ Number of measurements (for details see sub-section 4.9).

${ }^{2}$ In order to provide direct comparability within the multi-isotope data set of this study, we added to the usual and significant $95 \%$ confidence the classical SE level.

${ }^{3}$ Calculated on replicate measurements of the bracketing standard NIST SRM 683.

${ }^{4}$ Calculated on replicate measurements of the bracketing standard IRMM-14.

${ }^{5}$ Not measured.

\begin{tabular}{|c|c|c|c|c|c|c|}
\hline Sample Locati & ${ }^{87} \mathrm{Sr} /{ }^{86} \mathrm{~S}$ & $\left({ }^{230} \mathrm{Th} /{ }^{232} \mathrm{~T} 2 \mathrm{~S}\right.$ & ${ }^{238} \mathrm{U} / /^{232} 2 \mathrm{SD}^{234} \mathrm{U} /{ }^{238}$ & $2 \mathrm{SD}^{232} \mathrm{Th} /{ }^{23} \quad 2 \mathrm{SD}$ & ${ }^{230} \mathrm{Th} /{ }^{23}$ & 2SD Isochr $2 S \delta^{234} U^{9} 2 S$ \\
\hline ID on & $\mathrm{r}$ & h) ${ }^{6} \quad \mathrm{D}$ & $\begin{aligned} \text { Th } & \mathrm{U} \\
\text { (activity } & \text { (activit }\end{aligned}$ & $\begin{array}{l}{ }^{8} \mathrm{U} \\
\text { (activity }\end{array}$ & $\begin{array}{l}{ }^{8} \mathrm{U} \\
\text { (activity }\end{array}$ & $\begin{array}{l}\text { on }_{(\mathrm{kgr}} \mathrm{ag}^{7} \mathrm{D} \\
(\text { initia D }\end{array}$ \\
\hline
\end{tabular}




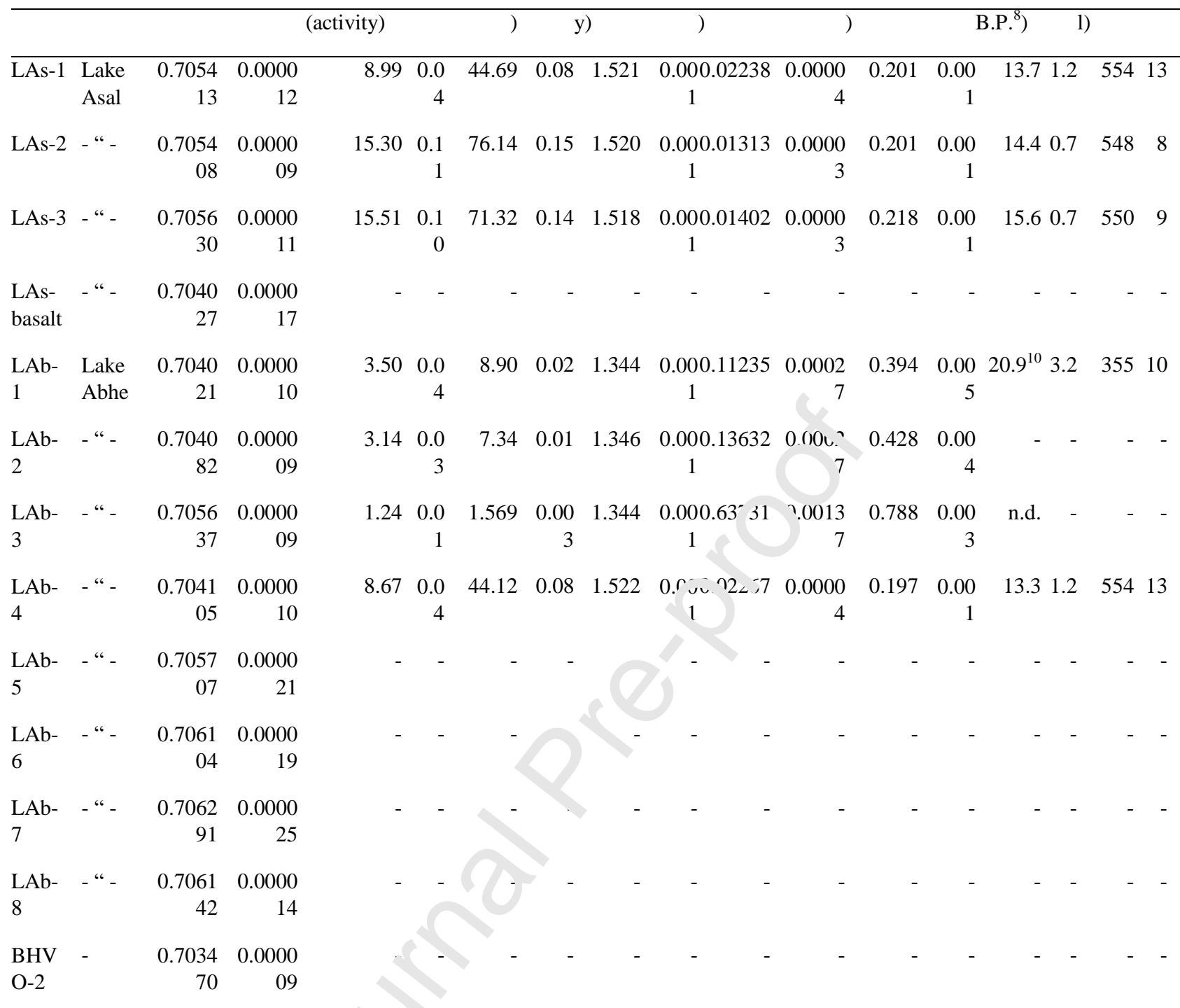

${ }^{6}$ All calculations of U-Th data have ist $\overline{ }{ }^{\prime}$ th half-lives measured by Cheng et al. (2013).

${ }^{7}$ Two-point isochron ages were $\mathrm{c}$ : Icula $\supseteq \mathrm{d}$ using a sediment end-member at secular equilibrium (i.e., activity ratio $=1 \pm 0.5$; samples LAb-4, LAs-1, LAs-'́, ' A. 2) Ages were calculated using the program Isoplot/Ex 4.15 (Ludwig, 2011) using a Monte Carlo simulation of 1000 steps for , ror calculation.

${ }^{8}$ B.P. stands for "Before Preser." . vhere the "Present" is defined as the year 1950 A.D.

${ }^{9}$ Initial $\delta^{234} U=\left(\left[{ }^{234} U /{ }^{238} U\right]_{\text {activity }}-1\right) \times 1000$, based on isochron ${ }^{230} \mathrm{Th}$ age and corrected from detrital contamination.

${ }^{10}$ A mean isochron age was calculated for samples LAb-1 and LAb-2.

Table 7 Isotope composition of the investigated fluid samples from the Afar Rift.

\begin{tabular}{|c|c|c|c|c|c|c|c|c|c|c|c|c|c|}
\hline Sample ID & Site ID & Location & Sample type & $\begin{array}{l}\delta^{13} \mathrm{C}_{\text {DIC }} \\
(\% \text { o } \\
\text { VPDB })\end{array}$ & $\begin{array}{l}\text { SD } \\
\text { (\%o) }\end{array}$ & $\begin{array}{l}{ }^{18} \mathrm{O}_{\mathrm{H} 2 \mathrm{O}} \\
\% \\
\% \text { SMOW) }\end{array}$ & $\begin{array}{l}\mathrm{SD} \delta \\
(\%)(\%\end{array}$ & $\begin{array}{l}{ }^{34} \mathrm{~S}_{\mathrm{SO} 4} \\
\% \text { o } \\
\left.{ }_{\mathrm{VCDT}}\right)\end{array}$ & $\begin{array}{l}\text { SD } \\
(\%)\end{array}$ & $\begin{array}{l}\delta^{44 / 40} \mathrm{Ca}_{\text {NIST }} \\
\text { SRM-915a }(\% o)\end{array}$ & $\begin{array}{l}95 \% \\
\text { conf. } \\
(\% o)\end{array}$ & $\mathrm{n}^{1}$ & $\begin{array}{l}\mathrm{SE} \\
(\%)\end{array}$ \\
\hline & Site 1 & Ghoubbet-al- & seawater & & 0.0 & & & 207 & & & & & - \\
\hline 1 & & Kharab & & -2.89 & 4 & 0.85 & 0.13 & 20.1 & 0.3 & $-^{2}$ & - & - & \\
\hline & & & & & 0.2 & & & 106 & & & & & 0.0 \\
\hline $\mathrm{C} 1-5$ (0 m) & $\mathrm{C} 1$ & Lake Asal & lake water & 6.27 & 9 & 4.21 & 0.35 & 19.0 & 0.3 & 1.47 & 0.08 & 3 & 3 \\
\hline C1-4 (5 m) & $\mathrm{C} 1$ & Lake Asal & lake water & 6.74 & 0.1 & 4.36 & 0.02 & 19.3 & 0.3 & 1.22 & 0.13 & 6 & 0.0 \\
\hline
\end{tabular}




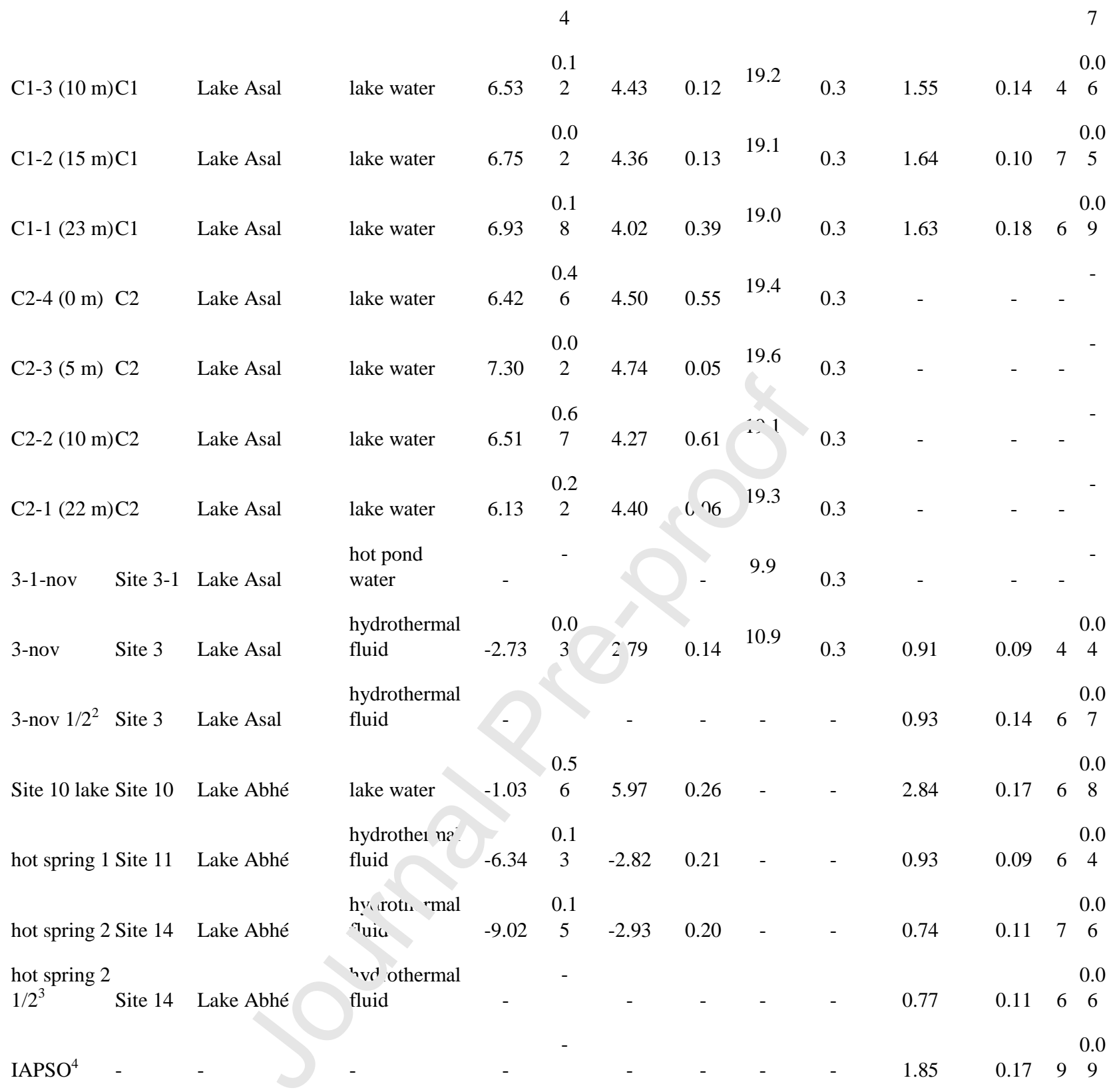

${ }^{1}$ Number of measurements (for details see sub-section 4.9).

${ }^{2}$ Not measured.

${ }^{3}$ Whole procedure duplicates done on half of the amount of the original sample (for details see sub-section 4.9).

${ }^{4}$ Mean seawater standard.

Sample ID Site ID Location Sample type $\delta$

$$
\text { SRM-683 }
$$

(\%o) (\%o) 14

(\%o) (\%o)

(\%o)

\begin{tabular}{|c|c|c|c|c|c|c|c|c|c|}
\hline Site 1 & $\begin{array}{l}\text { Ghoubbet-al- } \\
\text { Kharab }\end{array}$ & seawater & - & - & - & - & - & - & 0.709159 \\
\hline $\mathrm{C} 1-5(0 \mathrm{~m}) \mathrm{C} 1$ & Lake Asal & lake water & 0.02 & 0.07 & - & - & - & - & 0.7066190 .000036 \\
\hline $\mathrm{C} 1-4(5 \mathrm{~m}) \mathrm{C} 1$ & Lake Asal & lake water & -0.06 & 0.07 & - & - & - & - & 0.7066250 .000016 \\
\hline
\end{tabular}




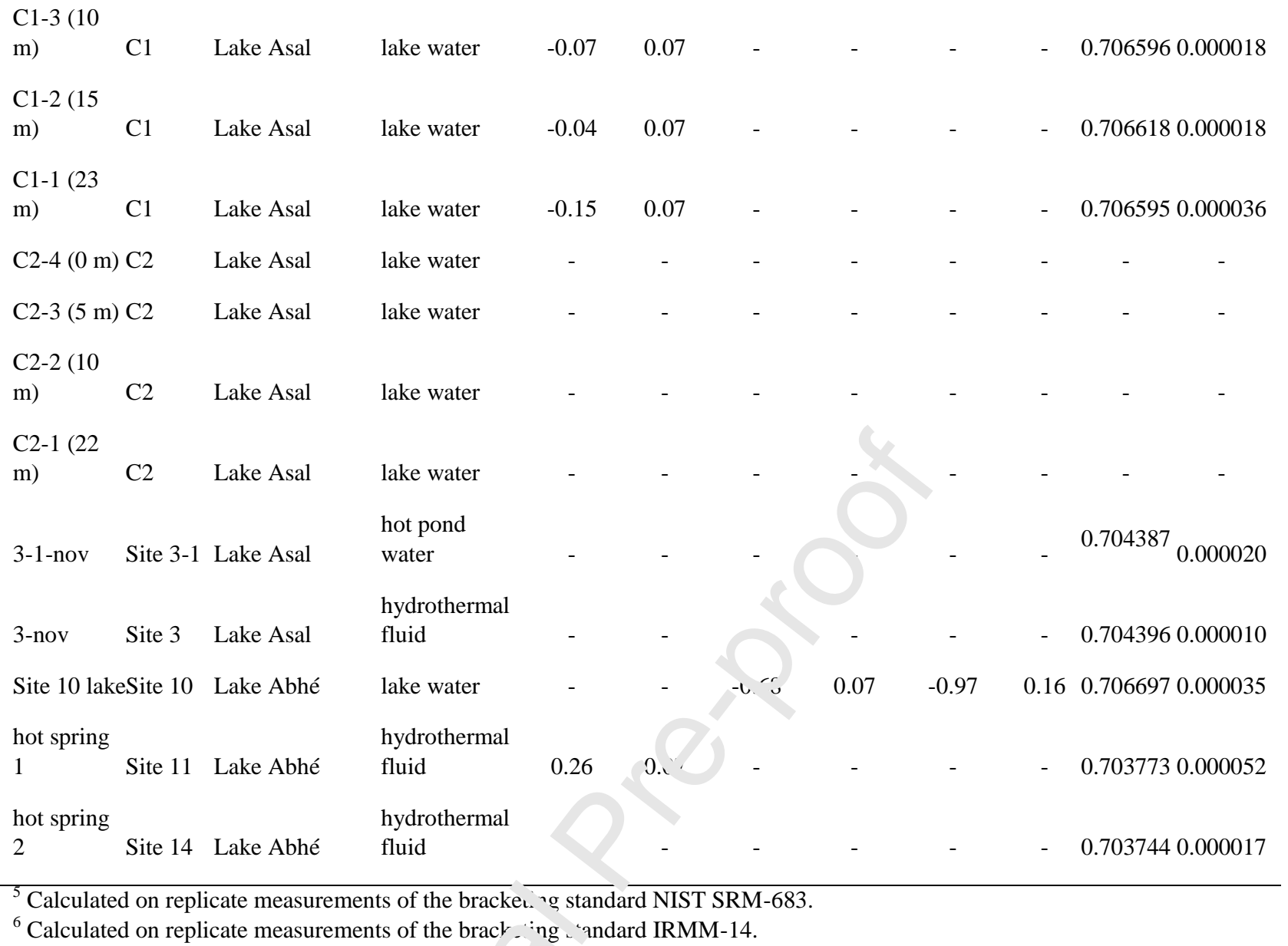

Table 8 Elemental ratios in the investigat : $\mathrm{d}_{\mathrm{L}}$. ia samples from the Afar Rift.

\begin{tabular}{|c|c|c|c|c|c|c|c|c|c|c|}
\hline $\begin{array}{l}\text { Sample } \\
\text { ID }\end{array}$ & $\begin{array}{l}\text { Site } \\
\text { ID }\end{array}$ & Location & Simp type & $\mathrm{Na} / \mathrm{Cl}$ & $\mathrm{K} / \mathrm{Cl}$ & $\mathrm{Ca} / \mathrm{Cl}$ & $\mathrm{Mg} / \mathrm{Cl}$ & $\mathrm{SO}_{4} / \mathrm{Cl}$ & $\mathrm{Br} / \mathrm{Cl}$ & Reference \\
\hline & & & $\begin{array}{l}\text { sf dwater, } \\
\text { average }\end{array}$ & 0.5566 & 0.0206 & 0.0213 & 0.0663 & 0.1400 & 0.0035 & $\begin{array}{l}\text { Millero, } \\
2003\end{array}$ \\
\hline 1 & Site 1 & $\begin{array}{l}\text { Ghoubbet-a. } \\
\text { Kharab }\end{array}$ & seawater & 0.5271 & 0.0265 & 0.0203 & 0.0664 & 0.1414 & -1 & $\begin{array}{l}\text { This } \\
\text { study }\end{array}$ \\
\hline $\begin{array}{l}\mathrm{C} 1-5(0 \\
\mathrm{m})\end{array}$ & $\mathrm{C} 1$ & Lake Asal & lake water & 0.2231 & 0.0135 & 0.0074 & 0.0300 & 0.0132 & 0.0030 & $\begin{array}{l}\text { This } \\
\text { study }\end{array}$ \\
\hline $\begin{array}{l}\text { C1-1 (23 } \\
\mathrm{m})\end{array}$ & $\mathrm{C} 1$ & Lake Asal & lake water & 0.2375 & 0.0143 & 0.0078 & 0.0319 & 0.0120 & 0.0033 & $\begin{array}{l}\text { This } \\
\text { study }\end{array}$ \\
\hline 3-1-nov & $\begin{array}{l}\text { Site } \\
3-1\end{array}$ & Lake Asal & hot pond water & 0.3102 & 0.0163 & 0.1084 & 0.0128 & 0.0116 & 0.0030 & $\begin{array}{l}\text { This } \\
\text { study }\end{array}$ \\
\hline 3-nov & Site 3 & Lake Asal & $\begin{array}{l}\text { hydrothermal } \\
\text { fluid }\end{array}$ & 0.3135 & 0.0170 & 0.1006 & 0.0147 & 0.0115 & 0.0031 & $\begin{array}{l}\text { This } \\
\text { study }\end{array}$ \\
\hline $\begin{array}{l}\text { Site } 10 \\
\text { lake }\end{array}$ & $\begin{array}{l}\text { Site } \\
10\end{array}$ & Lake Abhé & lake water & 0.8648 & 0.0233 & 0.00005 & 0.00003 & 0.4631 & - & $\begin{array}{l}\text { This } \\
\text { study }\end{array}$ \\
\hline
\end{tabular}




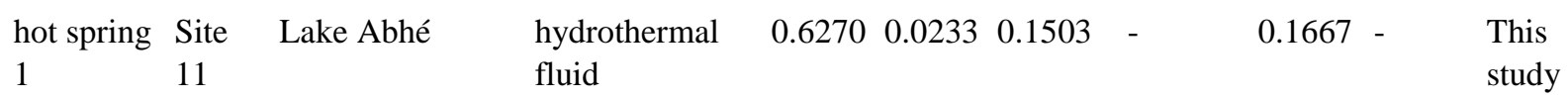

${ }^{\mathrm{T}}$ Not measured.

Table 9 Chemistry of the end-member hydrothermal fluid, Lake Asal.

\begin{tabular}{|c|c|c|}
\hline & $\begin{array}{l}\text { end-member hydrothermal fluid, Lake } \\
\text { Asal }^{1}\end{array}$ & $\begin{array}{l}\text { seafloor hydrothermal fluids, overall } \\
\text { range }^{2}\end{array}$ \\
\hline${ }^{87} \mathrm{Sr} /{ }^{86} \mathrm{Sr}$ & 0.704184 & \\
\hline $\mathrm{Y}(\mathrm{ppb})$ & 0.004 & \\
\hline $\mathrm{Cd}$ & 2.40 & $0-20.2$ \\
\hline $\mathrm{La}$ & 0.031 & \\
\hline $\mathrm{Ce}$ & 0.006 & \\
\hline $\mathrm{Nd}$ & 0.002 & \\
\hline $\mathrm{U}$ & $0.01^{3}$ & \\
\hline $\mathrm{V}$ & 74.0 & \\
\hline Mn & 411 & $549-390060$ \\
\hline $\mathrm{Fe}$ & 24.0 & 391 to 1396250 \\
\hline $\mathrm{Co}$ & 0.20 & $<0.30-831$ \\
\hline $\mathrm{Ni}$ & 2.01 & $129-211$ \\
\hline $\mathrm{Cu}$ & 5.01 & $0-10295$ \\
\hline $\mathrm{Zn}$ & $1.23^{3}$ & $0-196140$ \\
\hline Mo & 24.1 & \\
\hline $\mathrm{Pb}$ & 0.08 & $<4.14-808$ \\
\hline $\mathrm{Ag}$ & 0.35 & $<0.11-24.8$ \\
\hline $\mathrm{Sn}$ & 0.15 & \\
\hline \multicolumn{3}{|c|}{$\begin{array}{l}{ }^{1} \text { Calculated from the estimation that the hydrothermal fluid venting at Site } 3 \text { is a mix of } 97 \% \\
\text { actual end-member hydrothermal fluid and } 3 \% \text { lake water } \\
{ }^{2} \text { German and Von Damm (2006) } \\
{ }^{3} \text { Due to the accumulation of these elements in the lake water their contents in there are two } \\
\text { orders of magnitude higher than those in the Site } 3 \text { hydrothermal fluid. Thus, the calculated } \\
\text { concentrations in the end-member fluid are negative. Therefore, we use the concentrations of } \\
\text { these elements in Site } 3 \text { hydrothermal fluid. }\end{array}$} \\
\hline
\end{tabular}


Table 10 Metals accumulated in the Lake Asal water. average concentration in Lake Asal water $(\mathrm{mg} / \mathrm{kg})$ metals accumulated in Lake Asal water $(\mathrm{t})$

\begin{tabular}{lrr}
\hline $\mathrm{Li}$ & 6.290000 & 2516.000 \\
$\mathrm{Mn}$ & 1.026399 & 410.560 \\
$\mathrm{Zn}$ & 0.483303 & 193.321 \\
$\mathrm{Cu}$ & 0.011954 & 4.782 \\
$\mathrm{Mo}$ & 0.009632 & 3.853 \\
$\mathrm{Fe}$ & 0.007847 & 3.139 \\
$\mathrm{Ni}$ & 0.002256 & 0.903 \\
$\mathrm{~V}$ & 0.002250 & 0.900 \\
$\mathrm{U}$ & 0.001061 & 0.424 \\
$\mathrm{~Pb}$ & 0.000956 & 0.383 \\
$\mathrm{Co}$ & 5.015682 & 0.273 \\
$\mathrm{Sn}$ & 0.00532 & 0.213 \\
$\mathrm{Cd}$ & 6.000028 & 0.011 \\
$\mathrm{Ag}$ & 0.000019 & 0.008 \\
$\mathrm{La}$ & 0.000009 & 0.004 \\
$\mathrm{Y}$ & 0.000008 & 0.003 \\
$\mathrm{Ce}$ & 0.000006 & 0.002 \\
$\mathrm{Nd}$ & 0.000004 & 0.002 \\
$\mathrm{Pr}$ & 0.000001 & 0.0004 \\
\hline
\end{tabular}

${ }^{1}$ Calculated using the average metal concentration in the Lake Asal water and the water volume of Lake Asal, 400 million $\mathrm{m}^{3}$ (400000 million $\mathrm{kg}$ )

Highlights:

- Lake Asal (Afar Rift) is fed by seafloor-type hydrothermal fluids

- An oceanic "embryo" in arid climate is mildly acidic and metal rich

- It has heavy $\mathrm{C}, \mathrm{O}$ and $\mathrm{Ca}$, and light $\mathrm{Zn}$ isotope composition

- Lake chemistry is controlled by hydrothermal discharge and aeolian input 
Figure 1
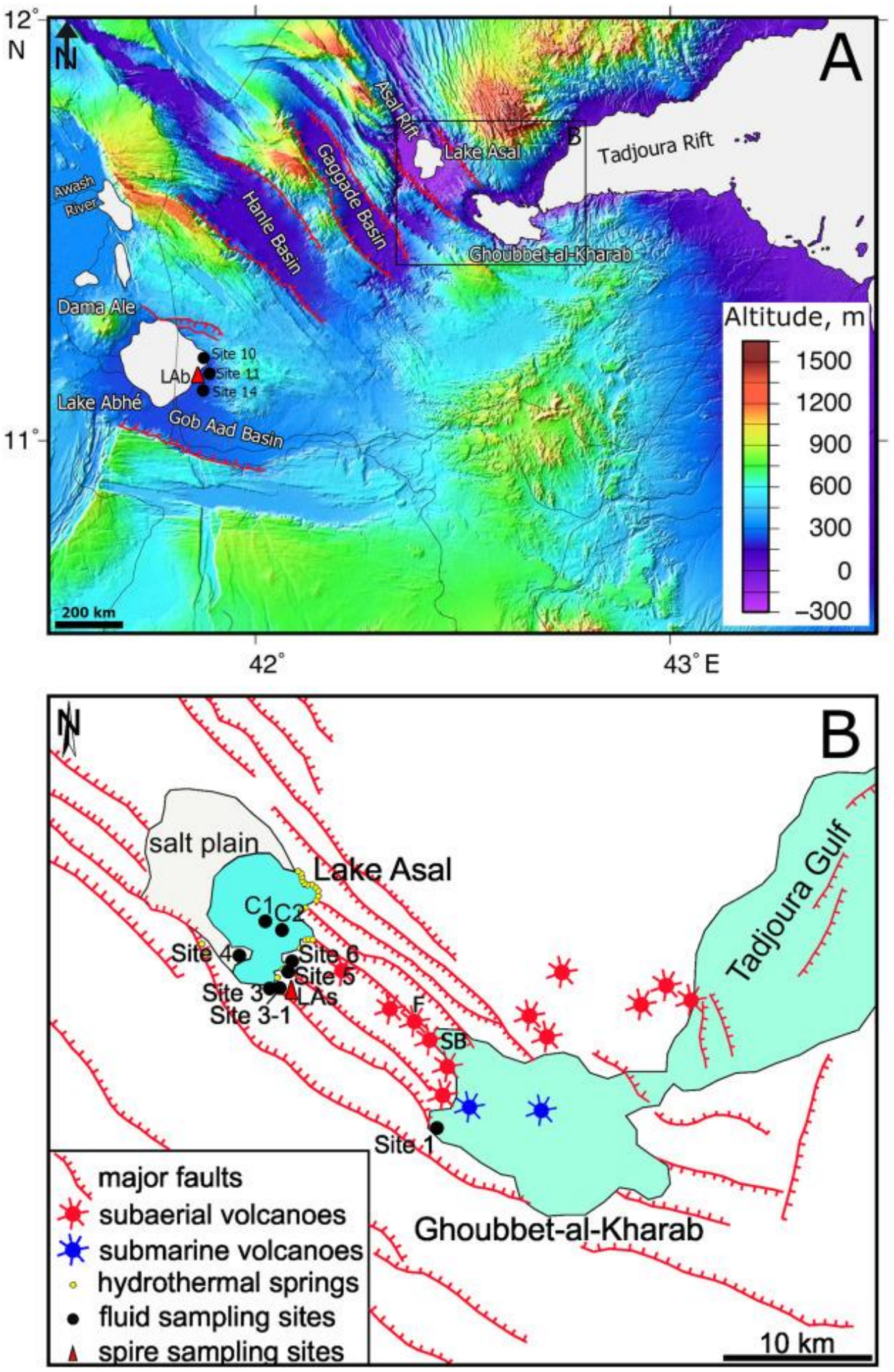
Figure 2
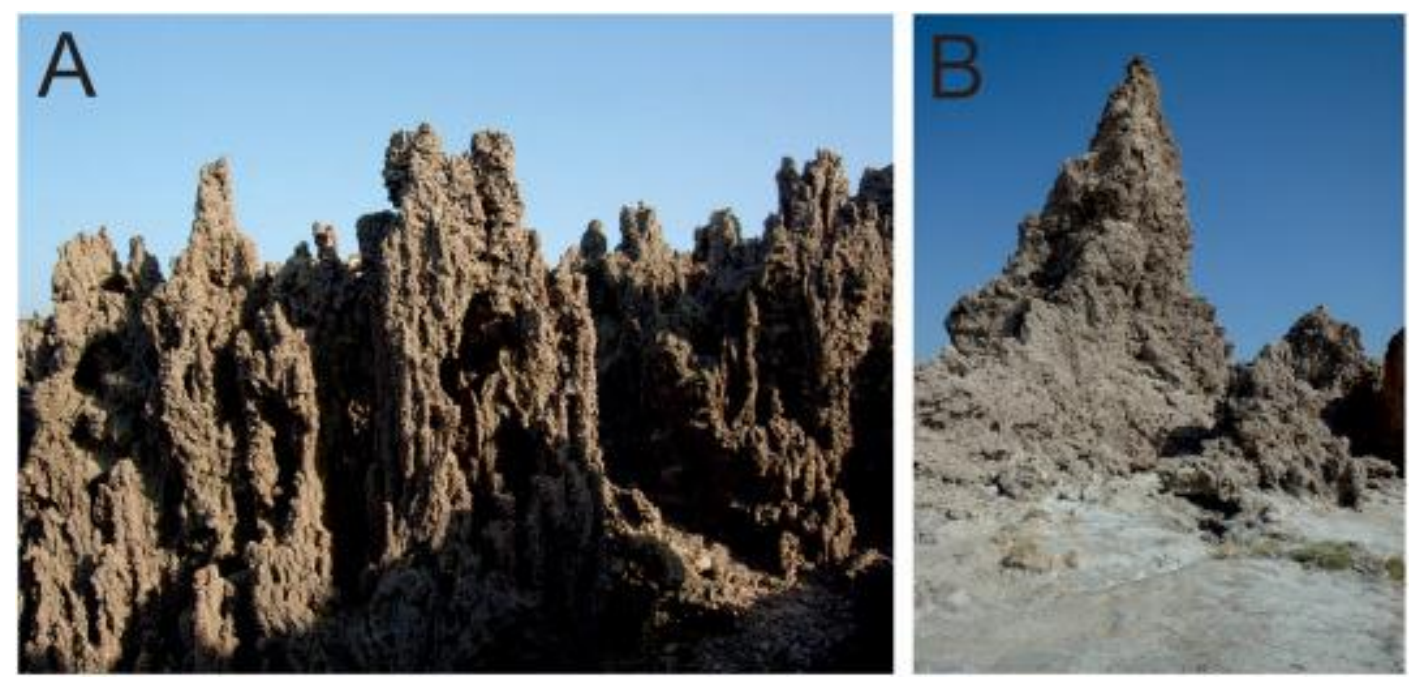

Figure 3
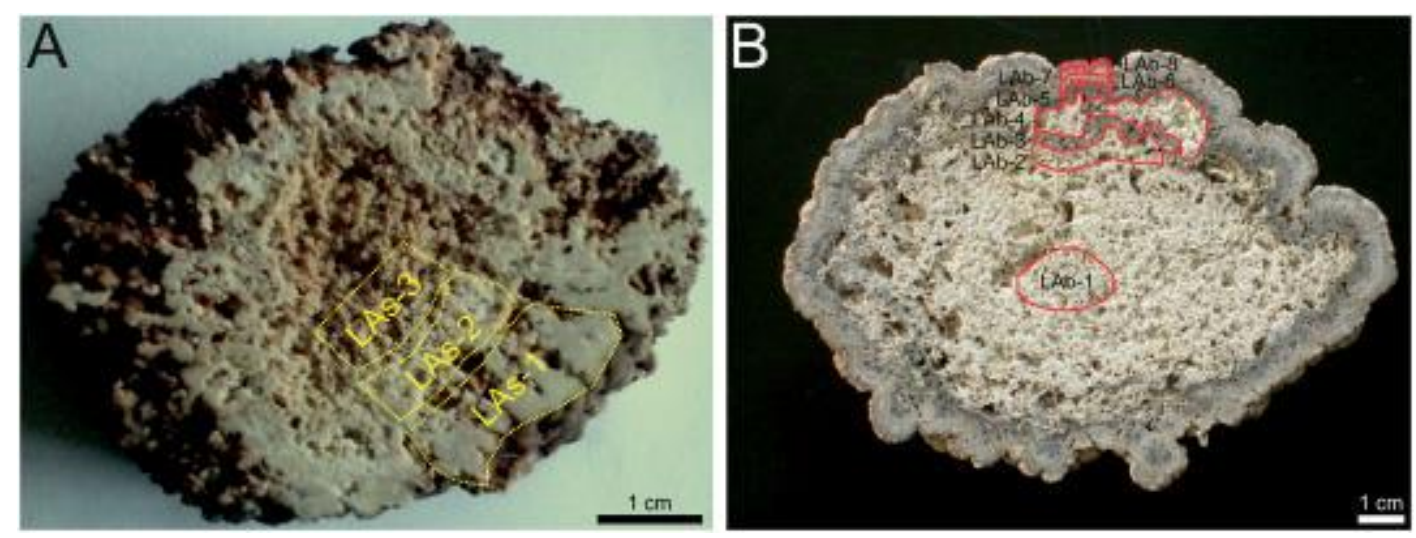
Figure 4
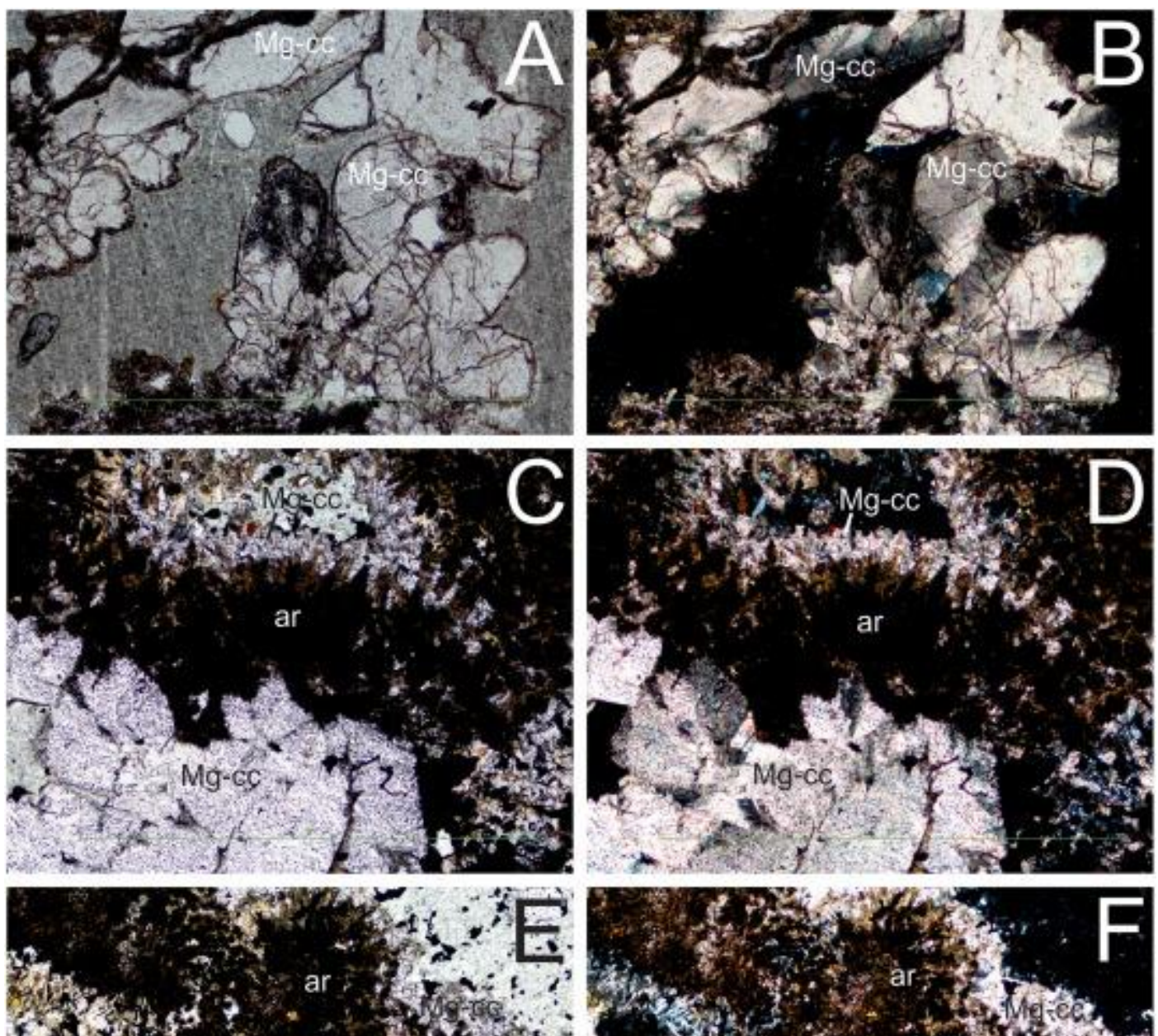

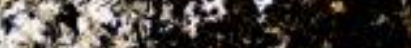

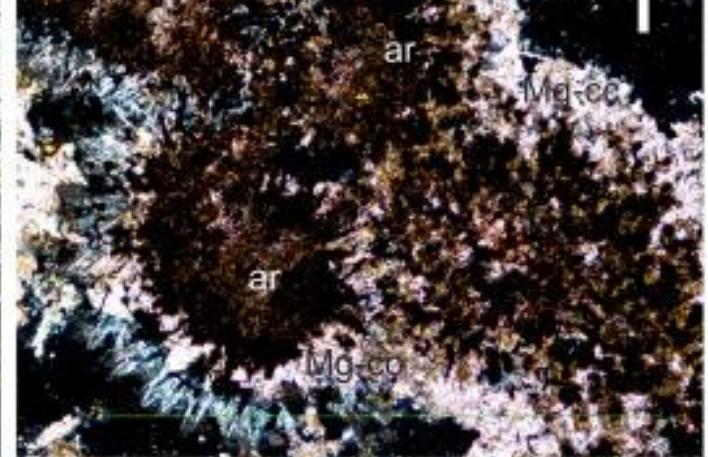

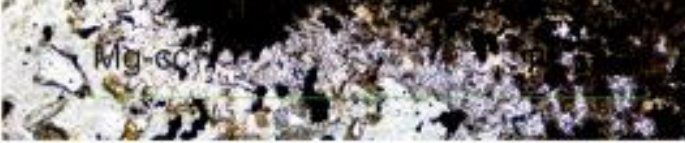
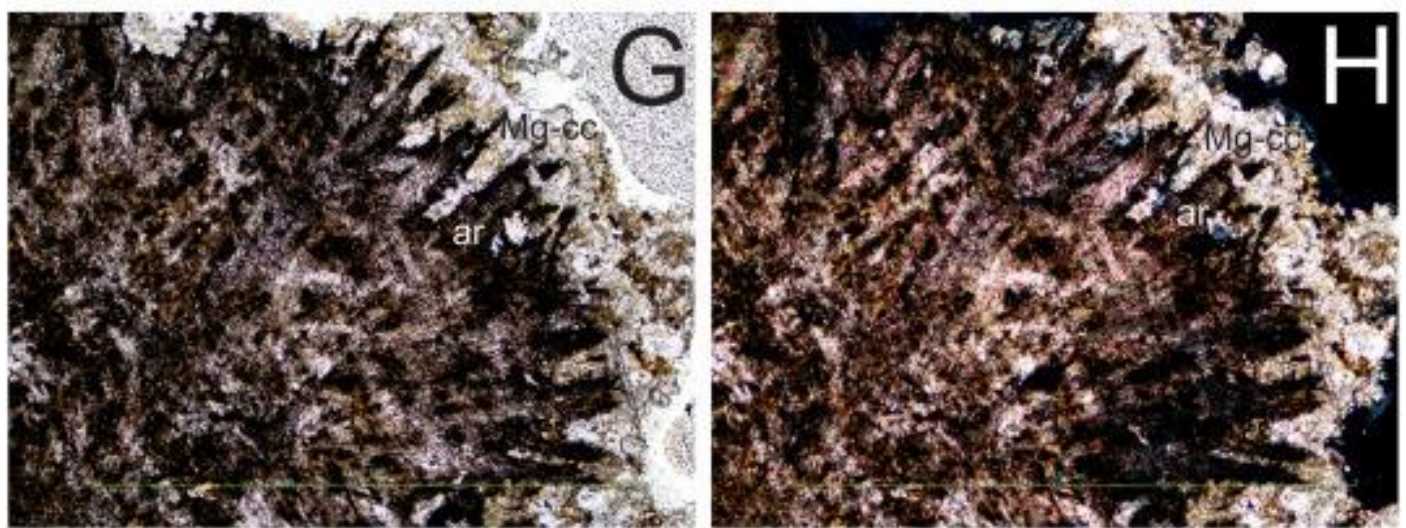
Figure 5
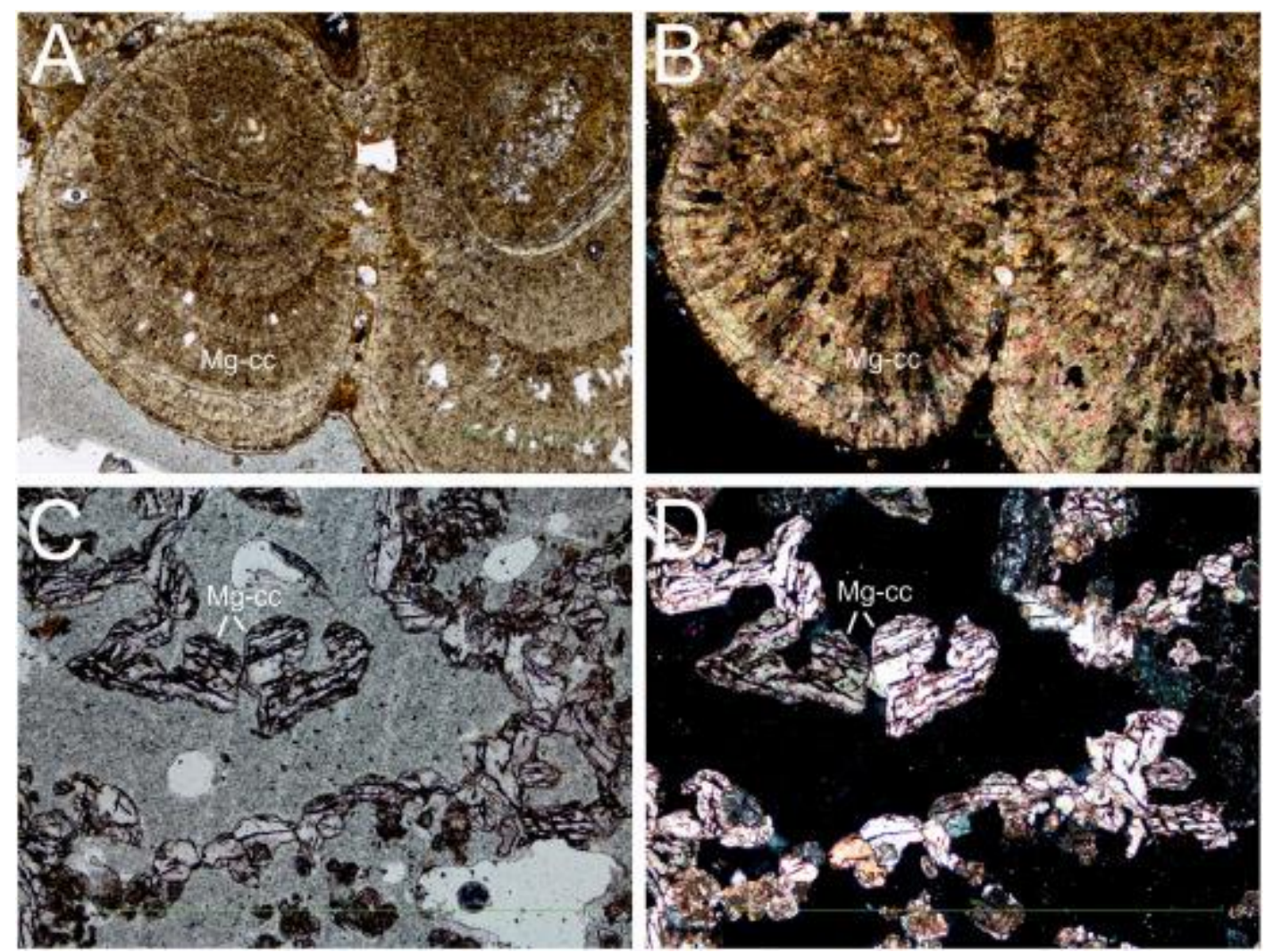
Figure 6

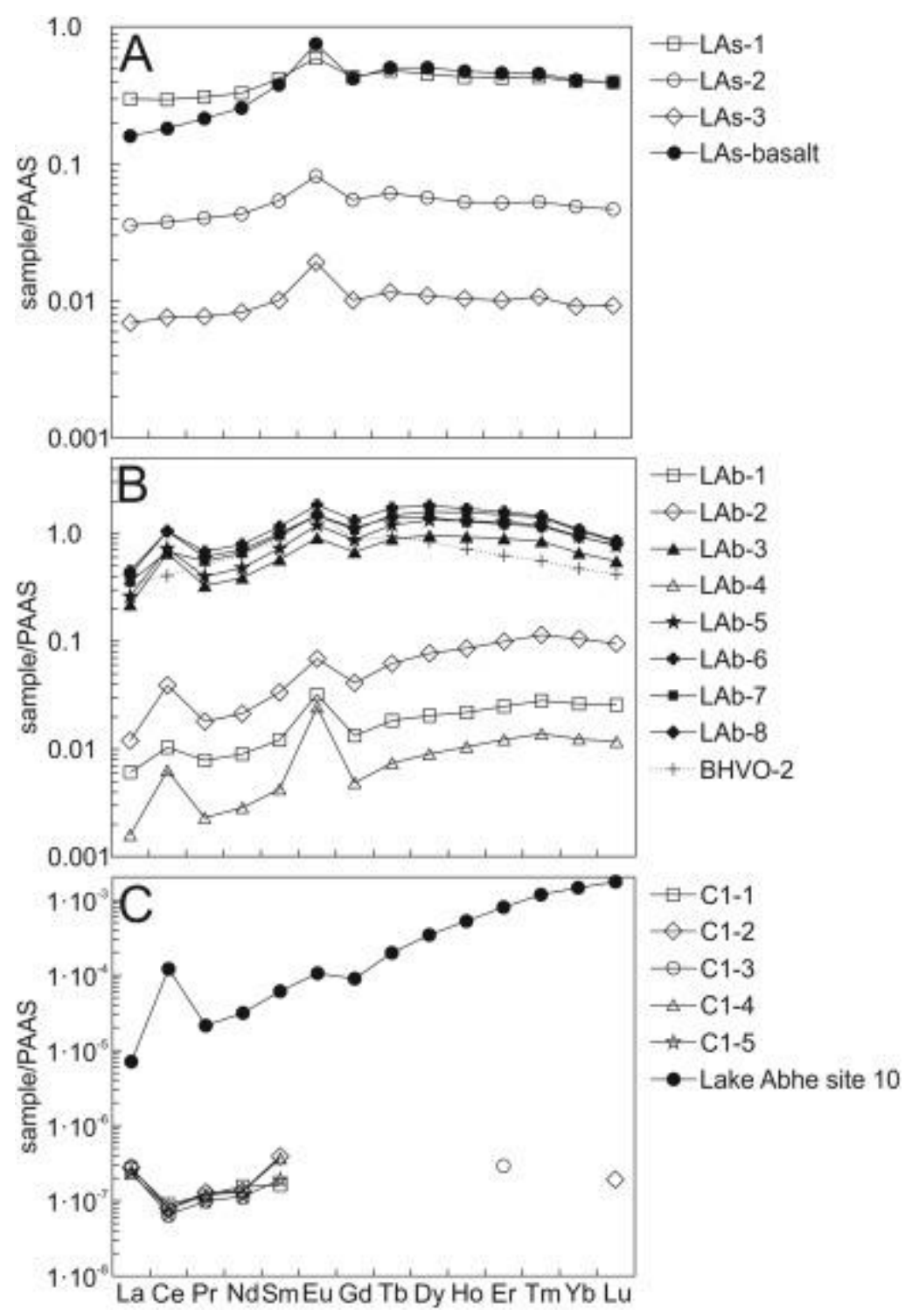


Figure 7
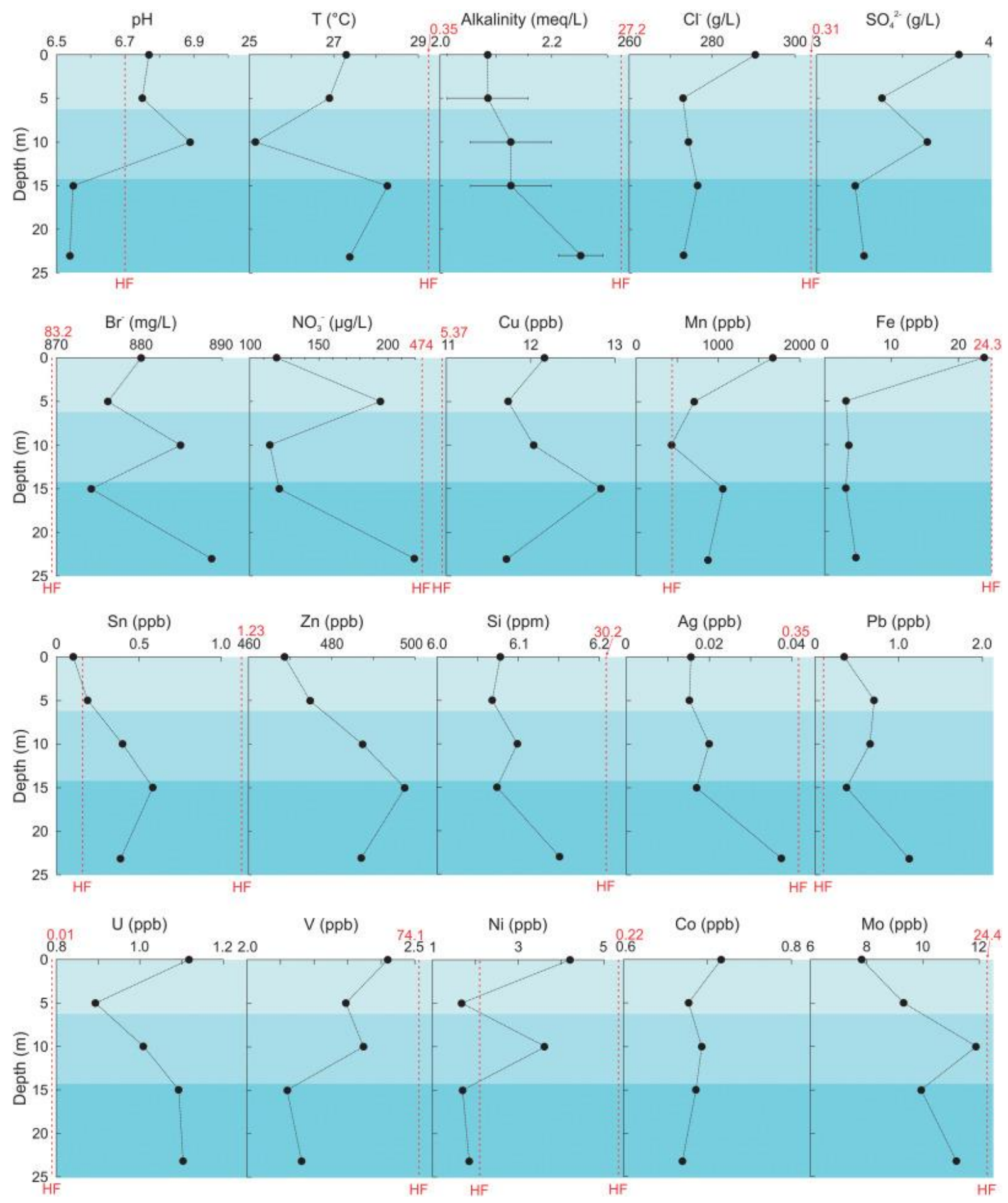


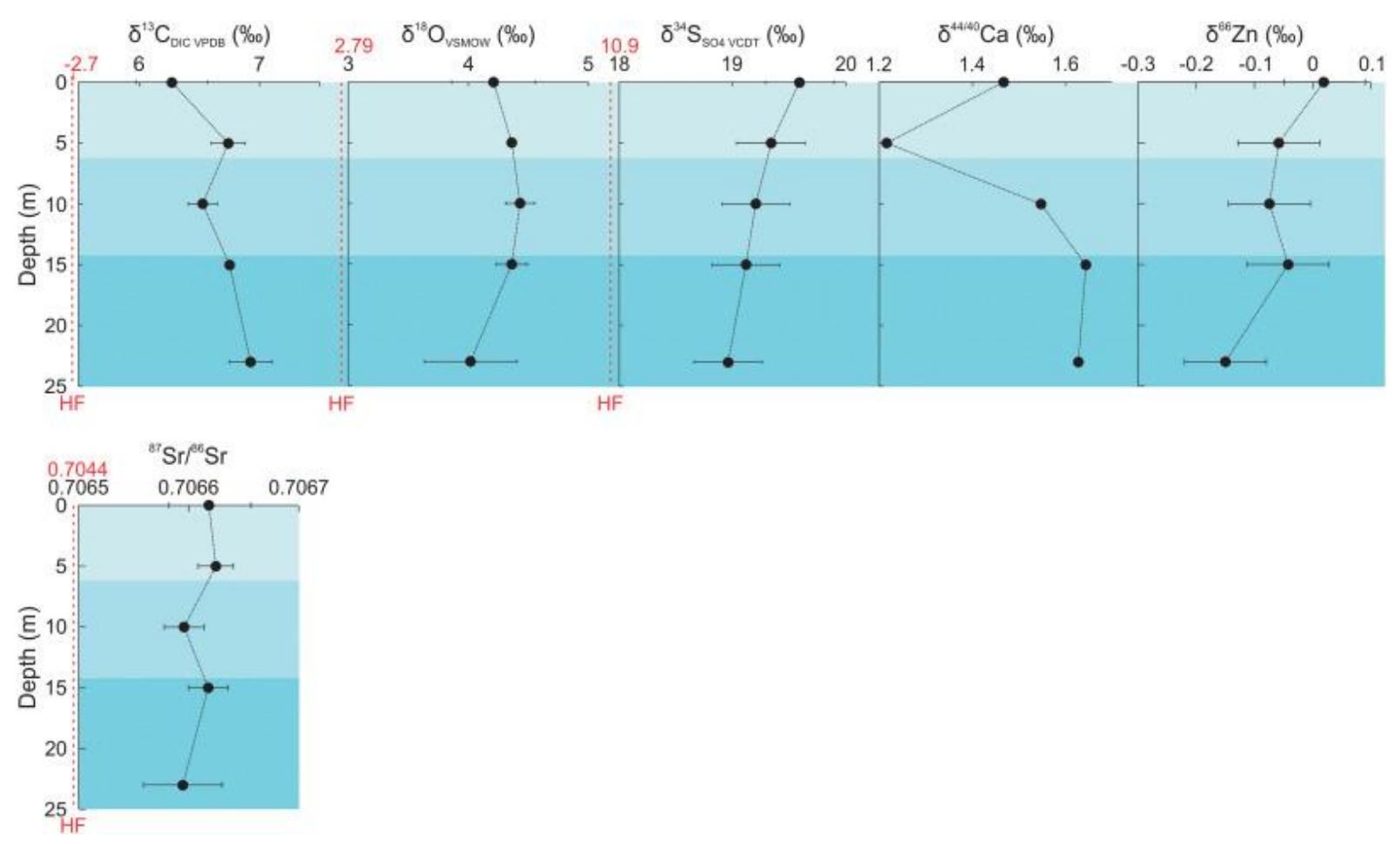

Figure 8

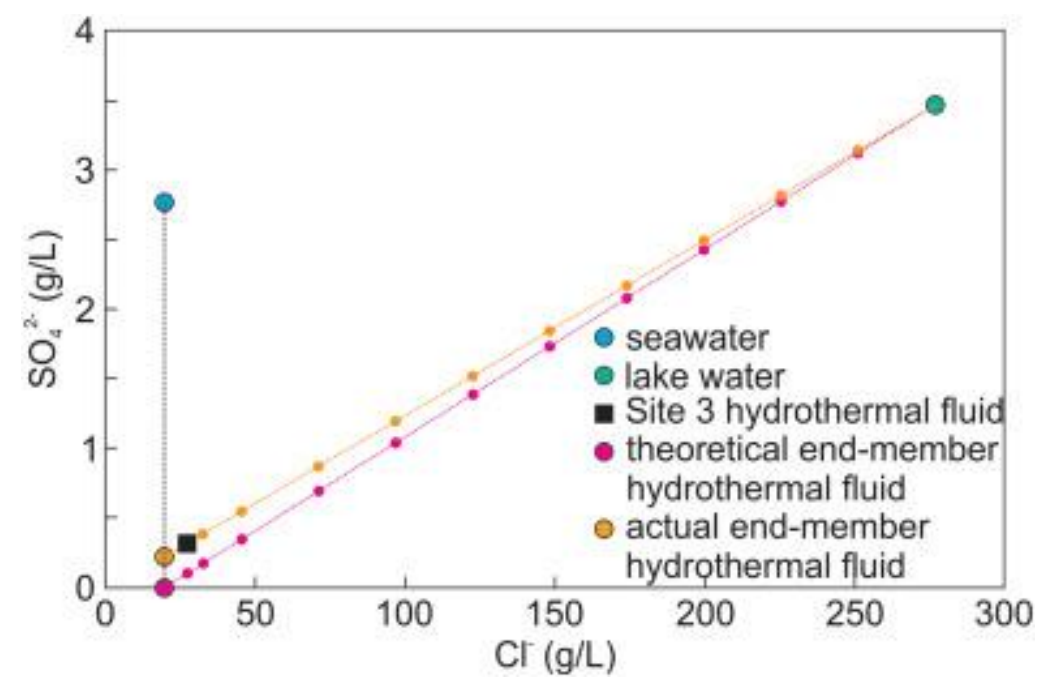


Figure 9
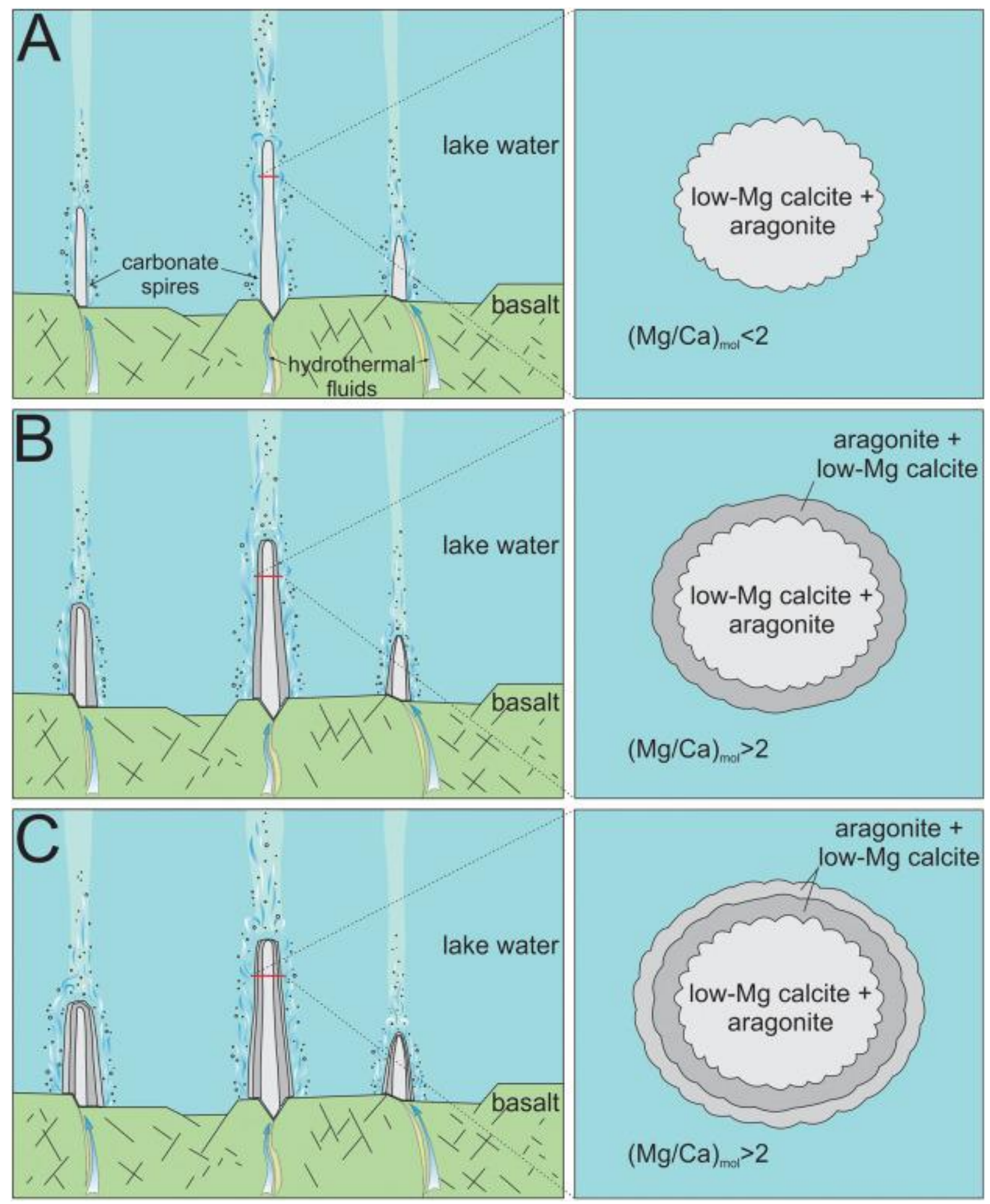
Figure 10
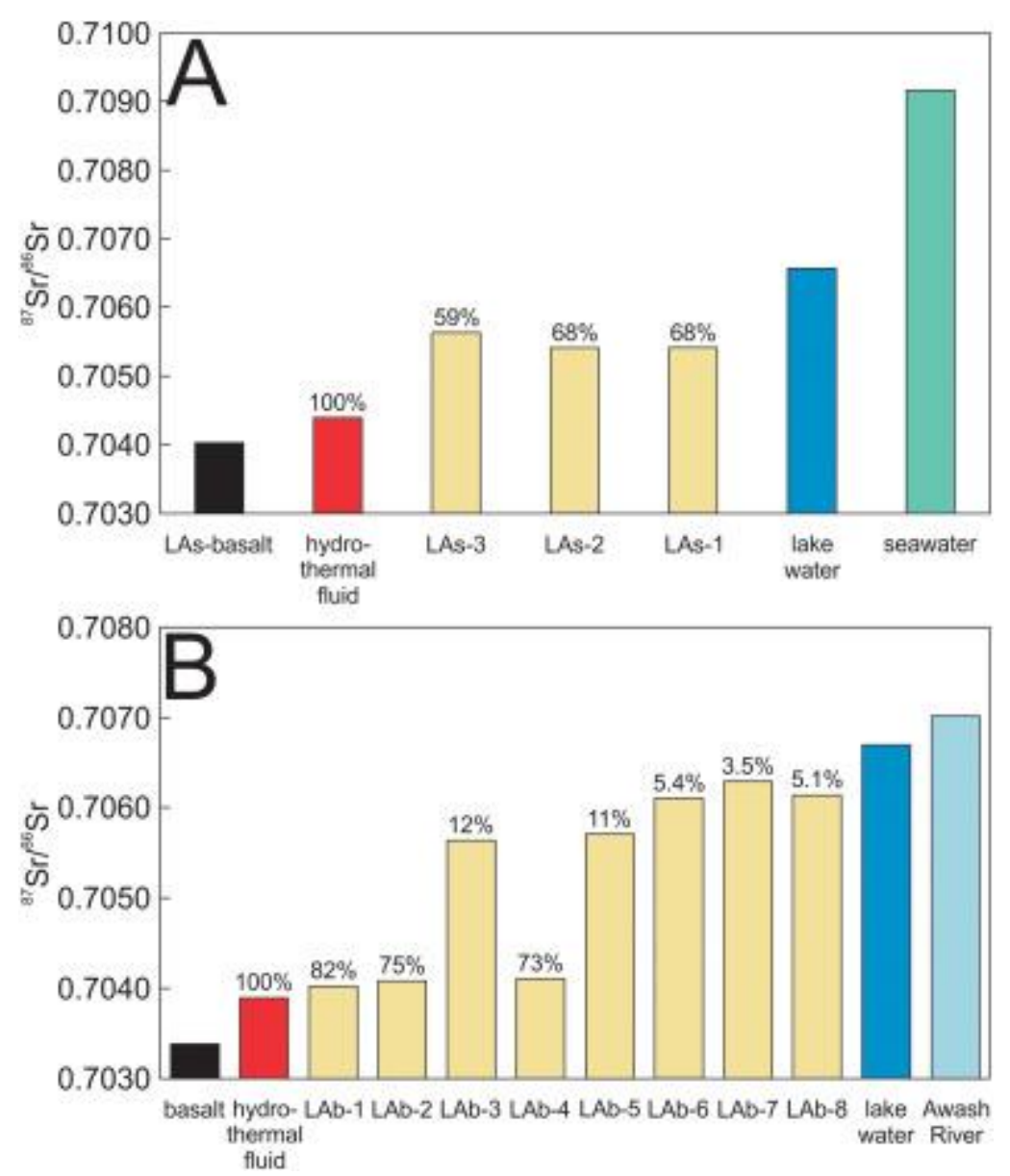
Figure 11
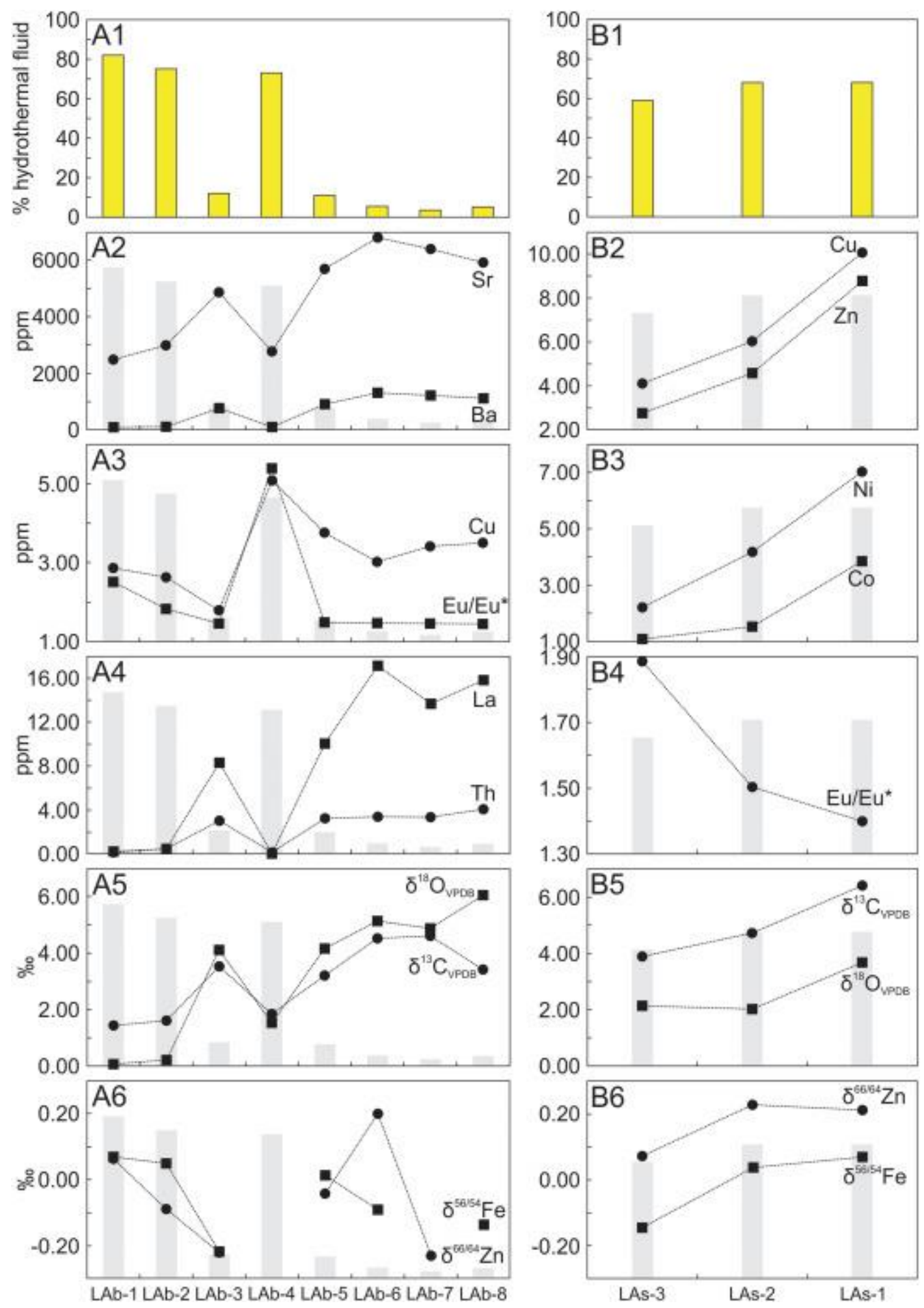
Figure 12
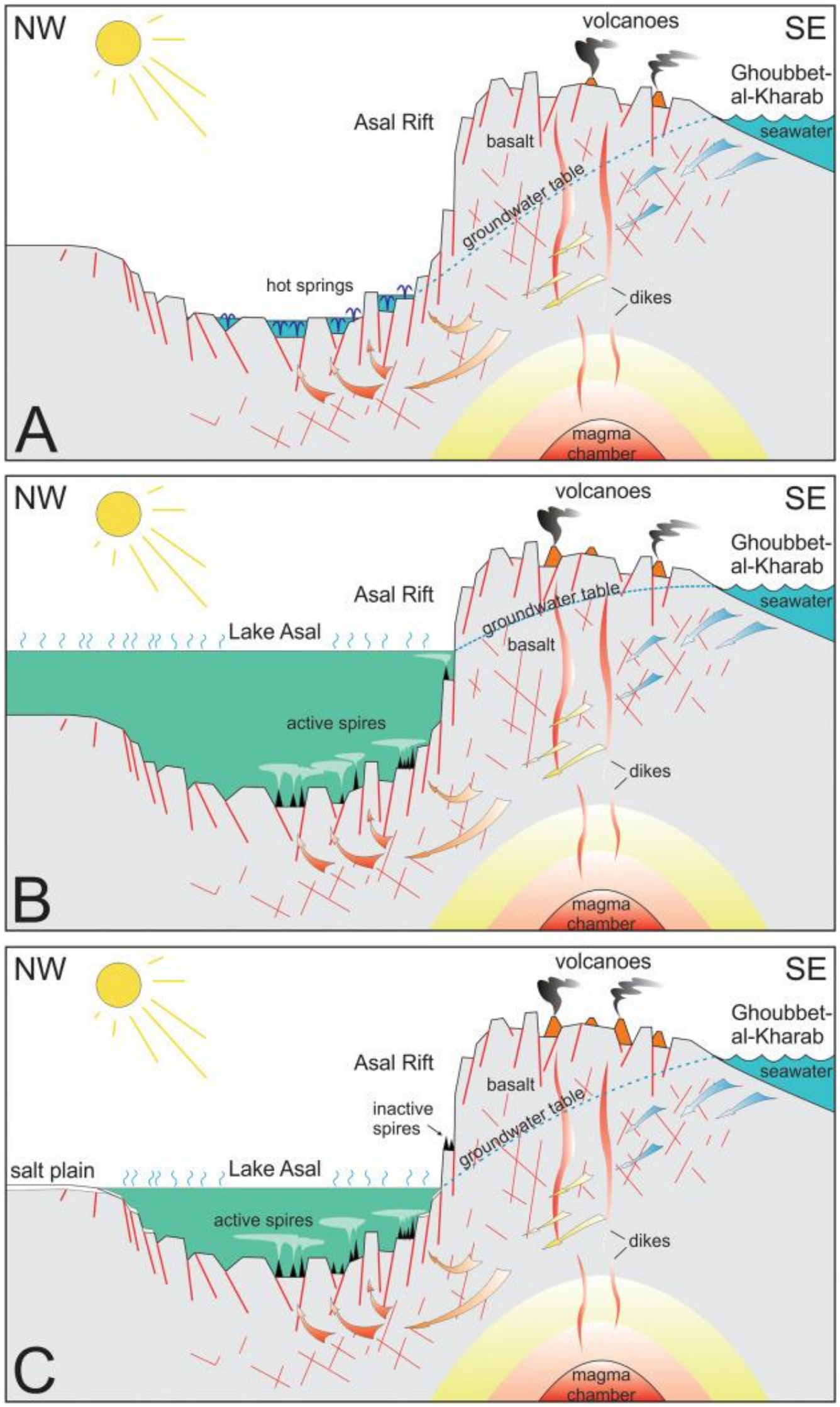
Figure 13

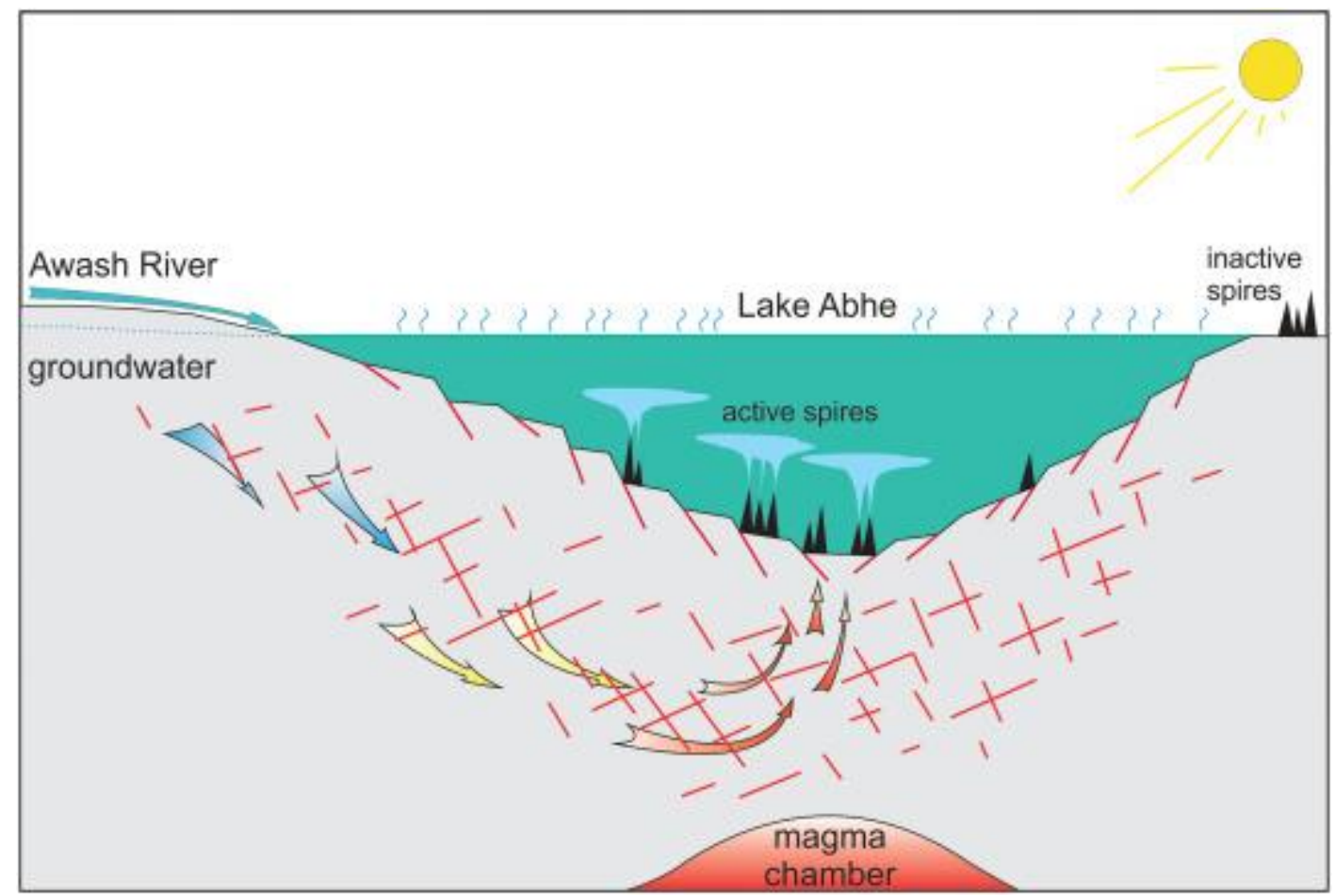

